\title{
Ukrainian Labourers in Nazi Germany, 1939-45
}

by

\author{
Stephen C. Telka, B.A.
A thesis submitted to the Faculty of Graduate Studies and Research in partial fulfillment of the requirements for the degree of

Master of Arts

Institute of European, Russian and Eurasian Studies

\author{
Carleton University \\ Ottawa, Ontario, Canada
}

September 2008

C2008, Stephen C. Telka 


$\begin{array}{ll}\begin{array}{l}\text { Library and } \\ \text { Archives Canada }\end{array} & \begin{array}{l}\text { Bibliothèque et } \\ \text { Archives Canada }\end{array} \\ \begin{array}{l}\text { Published Heritage } \\ \text { Branch }\end{array} & \begin{array}{l}\text { Direction du } \\ \text { Patrimoine de l'édition }\end{array} \\ \begin{array}{l}\text { 395 Wellington Street } \\ \text { Ottawa ON K1A 0N4 } \\ \text { Canada }\end{array} & \begin{array}{l}\text { 395, rue Wellington } \\ \text { Ottawa ON K1A 0N4 } \\ \text { Canada }\end{array}\end{array}$

Your file Votre référence ISBN: 978-0-494-43496-3 Ourfile Notre référence ISBN: 978-0-494-43496-3

NOTICE:

The author has granted a nonexclusive license allowing Library and Archives Canada to reproduce, publish, archive, preserve, conserve, communicate to the public by telecommunication or on the Internet, loan, distribute and sell theses worldwide, for commercial or noncommercial purposes, in microform, paper, electronic and/or any other formats.

The author retains copyright ownership and moral rights in this thesis. Neither the thesis nor substantial extracts from it may be printed or otherwise reproduced without the author's permission.
AVIS:

L'auteur a accordé une licence non exclusive permettant à la Bibliothèque et Archives Canada de reproduire, publier, archiver, sauvegarder, conserver, transmettre au public par télécommunication ou par l'Internet, prêter, distribuer et vendre des thèses partout dans le monde, à des fins commerciales ou autres, sur support microforme, papier, électronique et/ou autres formats.

L'auteur conserve la propriété du droit d'auteur et des droits moraux qui protège cette thèse. $\mathrm{Ni}$ la thèse ni des extraits substantiels de celle-ci ne doivent être imprimés ou autrement reproduits sans son autorisation.
In compliance with the Canadian Privacy Act some supporting forms may have been removed from this thesis.

While these forms may be included in the document page count, their removal does not represent any loss of content from the thesis.
Conformément à la loi canadienne sur la protection de la vie privée, quelques formulaires secondaires ont été enlevés de cette thèse.

Bien que ces formulaires aient inclus dans la pagination, il n'y aura aucun contenu manquant.

\section{Canada}




\begin{abstract}
This study focuses on the experience of ethnic Ukrainian labourers deployed to Nazi Germany during the Second World War, and argues that the Ukrainian case speaks to the flexibility and limits of racial policy, given the realities of waging war and sustaining the war effort. The purpose is to demonstrate the unique situation of Ukrainians, and attempt to untangle the confusing regulations and statuses of an ethnic group who found their treatment in the Reich not based on ethnicity like most other groups, but rather on their citizenship, largely Polish and Soviet. It traces the German use of labourers from Eastern Europe and Nazi Rassenkunde (racial science) to the German experience during the First World War, showing historical precedents to their deployment.
\end{abstract}




\section{Acknowledgements}

I would like to thank the many people whose various contributions over the last year have made the writing of this thesis possible.

Firstly, I would like to thank my advisor Dr. Jeff Sahadeo for his time and patience. Over the past year, and especially during the past summer, he has spent innumerable hours editing, guiding, advising, encouraging, and motivating, for which I am greatly appreciative. I would also like to thank my examiners Drs. Jennifer Evans and James Casteel. Dr. Evans support was especially appreciated during the final weeks of writing, as I frantically pulled this paper together.

I thank the Canadian Institute for Ukrainian Studies at the University of Alberta for granting me the generous Marusia and Michael Dorosh Master's Fellowship, the Ukrainian Canadian Foundation of Taras Shevchenko and the State of BadenWürttemberg for their financial support with language training in Ukraine and Germany, as well Carleton University's Institute for European, Russian \& Eurasian Studies and Faculty of Graduate Studies and Research for their various grants and scholarships that helped make my ambitious research and language training plans reality.

To my friends Cécile Moroni and Eti Antonova, in Mannheim, Germany, where this paper came together during a year-long exchange, thank you for spontaneity, creativity, and much-needed coffee and Mensa breaks. To my friends who supported me from afar in Geneva, London, Ottawa and Toronto, thank you for your kind words and thoughts as I saw this project through to end. To Marco Szczesniak, thank you for your unfaltering patience, understanding, all-around support and love. And lastly, to my family, thank you for your unending encouragement, love and support, without which this entire project would not have been possible.

I dedicate this paper to my grandparents Stephanie and Elias Makuch, and Rosalie and Fedir Telka for their perseverance and courage in surviving life in Nazi Germany as Ukrainian forced labourers in order to start their lives anew in North America. 


\section{Table of Contents}

Acknowledgements page iii

Introduction 1

1. The Background and Foundation of Ukrainian Labour in Germany 19

2. The Twisted Route to Labour Deployment 48

3. The Ukrainian Everyday in Nazi Germany 79

$\begin{array}{ll}\text { Conclusion } & 139\end{array}$

$\begin{array}{ll}\text { Bibliography } & 144\end{array}$ 


\section{Introduction}

The Second World War was a war of unprecedented scale and scope. Some of the greatest cities of the western and eastern worlds were reduced to rubble. Millions of lives were obliterated, subjected to violent battle tactics and perverted theories of cultural superiority and racial supremacy. Not only were political boundaries redrawn, and the balance of world power irrevocably altered, the war changed the lives of millions of individuals the world over. Millions perished, and countless others were left without food, shelter and family. At the heart of the eastern European theatre of conflict were the territories inhabited by ethnic Ukrainians, divided largely between the Soviet Union and Poland at the outbreak of war in 1939. By the time the Germans commenced their eastern campaign 'Operation Barbarossa' with the invasion of the Soviet Union on 22 June 1941, the Polish Ukrainian territory of Eastern Galicia had been incorporated into the Soviet Union. Ukraine was thereby (briefly) unified and incorporated into the USSR under the rule of Joseph Stalin.

Nazi Germans infiltrated the cities, towns and villages of Eastern Galicia and Soviet Ukraine, exposing German soldiers and occupation officials to a regime that their government posited as Germany's antithesis. And in a unique process in modern history, Ukrainians were in turn introduced to the heartland of their declared enemies with the commencement of a massive migration scheme that sent over 2.4 million Ukrainians to labour in the German Reich. ${ }^{1}$ Ukrainians were transferred from one totalitarian regime to

\footnotetext{
${ }^{1}$ Gelinda Grinchenko, "Oral Histories of Former Ukrainian Ostarbeiter: Preliminary Results of Analysis," (Toiling for the Reich: Life Stories of Former Forced and Slave Laborers under Nazi Rule, 1939-1945, forthcoming 2008), 194. The term German Reich or Third Reich refers to the territory of Germany and period of German history under the rule of Adolf Hitler and the National Socialists, between 1933 and 1945. Hitler posited his rule as the third of three great periods in German history, preceded by the Holy Roman Empire as the First Reich and the 1871-1918 monarchy as the Second.
} 
another, opening their eyes to the greater European continent and twentieth century modernity while challenging their conceptions of culture, society and identity. These uprooted Ukrainians were forced to navigate a confusing sea of allegiances and concerns, balancing loyalties to family, nation and political system. Whereas for some the initial transfer was voluntary, with Ukrainians registering eagerly for a chance to escape the effects of the conflict and Soviet rule, for most it was done against their will, a forced exile from family, friends and their homeland. In 1945, the process repeated itself as the Allied victors dealt with the millions of Europeans displaced by the war. The end of the conflict inaugurated a period of further deportations and migrations, both east and west, as Ukrainians attempted to make sense of their status in postbellum Europe.

This study focuses on the experience of ethnic Ukrainian labourers deployed to Nazi Germany during the Second World War, and argues that the Ukrainian case speaks to the flexibility and limits of racial policy, given the realities of waging war and sustaining the war effort. Race was not the final determinant in shaping the fate and experience of Ukrainian labourers. My goal is to demonstrate the unique situation of Ukrainians, and attempt to untangle the confusing regulations and statuses of an ethnic group who found their treatment in the Reich not based on ethnicity like most other groups, but rather on their citizenship, largely Polish and Soviet. This study places the treatment of ethnic Ukrainians in the Reich within the greater context of German colonial plans in Eastern Europe, which were influenced by imperialist and expansionist socialDarwinist thinking adopted by the Nazi regime. It traces the German use of labourers from Eastern Europe and Nazi Rassenkunde (racial science) to the German experience during the First World War, showing historical precedents to their deployment. 
The Reichseinsatz, the labour program that found Ukrainians and other foreigners toiling on the farms and in the factories of the Third Reich, was the most import instance of forced labour by foreign workers outside their home country in the twentieth century. The program was a critical aspect of the German war effort, which by autumn 1940 the Germans had become heavily and irreversibly dependent on. ${ }^{2}$ By the end of the war, foreigners made up half of all agricultural workers, half of all munitions employees, and one third of the workforce in metal, chemical, construction and mining industries. ${ }^{3}$ Every fourth tank and plane, for example, was built by a foreigner. ${ }^{4}$ In total, 12 million foreigners were put to work in the "Greater German Reich." At the height of the program in August 1944, the program employed 7,615,970 foreign workers, of which 5.7 million were civilians, and 1.9 million POWs. ${ }^{5}$ The three largest national groups were 1.3 million French, 1.7 million Poles and 2.8 million Soviet citizens, referred to as Ostarbeiter, or Eastern Workers. ${ }^{6}$ When ethnicity, rather than citizenship, is taken into account in the fluid national boundaries of Eastern Europe, Ukrainians stand out as the largest contingent of foreign workers. A total of 2.4 million ethnic Ukrainians toiled for the Reich. $^{7}$ As the largest contingent of foreign workers in the Reich, and therefore, one of the most critical groups to the German war effort, Ukrainian labourers in Nazi Germany deserve special attention.

\footnotetext{
2 Ulrich Herbert, Hitler's Foreign Workers: Enforced Foreign Labor in Germany under the Third Reich (Cambridge: Cambridge University Press, 1997), 1.

${ }^{3}$ Ibid.

${ }^{4}$ Reinhold Billstein, Karola Fings, et. al., Working for the Enemy: Ford, General Motors and Forced Labor in Germany during the Second World War (New York: Berghahn Books, 2000), 7.

${ }^{5}$ Herbert, Hitler's Foreign Workers, 298.

${ }^{6}$ Ibid.

${ }^{7}$ Mark Spoerer, Zwangsarbeit Unter dem Hakenkreuz: Ausländische Zivilarbeiter, Kriegsgefangene und Häftlinge im Deutschen Reich und im besetzten Europa 1939-1945 (Stuttgart: Deutsche Verlags-Anstalt, 2001), 80; Grinchenko, “Oral Histories,“ 194.
} 
This study attempts to fill a gap in the history of the Ukrainian nation, at its time of transformation into a unified nation-state. It deals with the history of a formerly stateless ethnic group, who lived on the territories of a variety of $20^{\text {th }}$-century states: Austria-Hungary, Poland, the Russian Empire, the Soviet Union, Romania and Czechoslovakia. In an era in which race and ethnicity were such critical identifying factors, the Ukrainians serve as a fascinating anomaly, in their ambiguous classification within the almighty Nazi racial-political hierarchies. At the outbreak of the war with Poland, the largest populations of ethnic Ukrainians lived in the Polish Republic and Soviet Union. A total of seven million Ukrainians lived in the Polish provinces of Galicia and Volhynia, while twenty million lived in the Russian-controlled Soviet Union. After the Romanian invasion of Transnistria (including Odessa) in 1941, one million Ukrainians became Romanian subjects, with a further 550,000 Ukrainians in Hungarianoccupied Carpatho-Ukraine. ${ }^{8}$ The focus of this study, however, is the two largest groups of ethnic Ukrainians, from Poland and the Soviet Union. Despite their common ethnicity, the two groups of Ukrainians were classified differently, and thus afforded differing treatment in Germany. Such a division of Ukrainians in the eyes of German officialdom prompts one to question the idea of a united Ukraine, and the significance of using diverging political and historical backgrounds to differentiate ethnic groups.

The story of Ukrainian labourers in National Socialist Germany has not been fully told in contemporary English-, German-, Russian- and Ukrainian-language World War II historiography. It has only been within the past two decades since the collapse of the Soviet Union that interest in the general topic of Nazi forced labour has turned into

\footnotetext{
${ }^{8}$ Orest Subtelny, Ukraine: A History (Toronto: University of Toronto Press, 1988), 458; Dinu C. Giurescu, Romania in the Second World War, (Boulder: East European Monographs, 2000), 169.
} 
substantial scholarship, and historians have began to fill critical 'black holes' in the history of the twentieth century. Until that time, the entire forced labour phenomenon was for the most part forgotten by academics in both the 'West' and 'East.' This study stands out amongst current scholarship on Nazi-era foreign forced labour in a few areas. It is the first comprehensive English-language study focusing solely on the experience of ethnic Ukrainians in Nazi Germany from both jurisdictions; all other accounts of ethnic Ukrainian labourers have been part of more general forced labour studies. The study is also novel in examining why Polish and Soviet Ukrainians received different treatment. Thirdly, it takes a unique approach in tracing the treatment of Ukrainians in the Reich to German colonial plans for the East. Lastly, and perhaps most significantly, this is the first study ever to explore the everyday experience of Ukrainian foreign labourers in the Reich.

General scholarship on the issue of prisoners of war during the Second World War, specifically Bob Moore and Kent Fedorowich's Prisoners of War and their Captors in World War II, touches on a number of important issues related to Ukrainian labourers in Nazi Germany. ${ }^{9}$ In particular is the ideologically-based treatment afforded to different nationalities of POWs at the hands of the British. Italian POWs were deemed by the British as inherently good, but under the spell of a powerful fascist dictator, swaying them away from their inherent qualities. Germans, conversely, were seen as inherently evil, and therefore unreformable. Italian and German POWs caught by the British were treated differently. This ideologically-based treatment of nationalities is reflected similarity in the German treatment of Soviet POWs as opposed to French and British

\footnotetext{
${ }^{9}$ Bob Moore and Kent Fedorowich, eds., Prisoners of War and Their Captors in World War II., (Oxford: Berg, 1996).
} 
nationals. Western Europeans were basically seen by Nazi officials as easily impressionable with a high probability of reeducation to support the Nazi cause. Soviet citizens, frequently labelled 'Russians' for the bulk of the war, on the other hand, were seen by Germans as barbaric, racially inferior, and a threat to the German race. Identity, as one can see, played an enormous role in the lives of prisoners captured by the enemy.

In the German Democratic Republic, foreign labourers in the Third Reich was somewhat of a 'hot topic' as early as the 1950 s. Research was filtered through a prism of Marxism-Leninism. Blame for wartime misgivings and maltreatment was placed on big business, for example, with the roles of the National Socialist state and party receiving only secondary treatment. The early 1970s saw the development of more differentiated approaches in the GDR, associated with a Rostock University-based research team, and represented in their standard work Deutschland im zweiten Weltkrieg. ${ }^{10}$ In particular, the team concentrated on public attitudes to the war effort and the deployment of foreign workers. It was concluded that a broad public consensus existed amongst the Third Reich population toward Nazi war policy, and their policy on foreign labourers.

The topic garnered even less attention in the former Soviet Union. The preeminent historian on Nazi foreign labourers, Ulrich Herbert, posits that the public disregard for the labour experience can be attributed to the obscurity of the Ostarbeiter fate upon returning to the Union. ${ }^{11}$ He perpetuates a long-held belief that returning Ostarbeiter were largely sent to Soviet Gulags, where many disappeared, perished and

\footnotetext{
${ }^{10}$ See the series Wolfgang Schumann, Gerhart Hass, Karl Drechsler, Deutschland im zweiten Weltkrieg, 5 vols. (Köln: Pahl-Rugenstein, 1974-84).

${ }^{11}$ Herbert, Hitler's Foreign Workers, 8.
} 
were never accounted for. ${ }^{12}$ While the Soviet leadership certainly had no desire to openly discuss the fate of returnees, Soviet historical silence on the topic can more significantly be attributed to the challenge returnees presented to newly-formed fundamental core beliefs of the regime, related to the experience of the "Great Patriotic War." The experience of Soviet citizens working abroad for the 'fascist enemy' conflicted with the Soviet narrative of an unwavering and dedicated struggle by every citizen against the 'Hitlerite' invaders. As Ukrainian historian Gelinada Grinchenko writes, "because the memory of forced labour in Nazi Germany did not fit within the triumphalist narrative of Soviet history, with its rhetorical emphasis on the mass heroism and patriotism of Soviet citizens, labour in the enemy's territory and for the enemy's benefit could not be excused even by its forced nature."13 The process of transposing the war events into a set of wellordered reminiscences was "to give new legitimacy to the [Soviet] regime at the moment when the revolution became faraway and faded memory, and an urgent need arose to confirm the indisputable right of the...leader to be the head of the country." ${ }^{14}$ This glorious victory over fascism became not only an important ideological component in the legitimisation of the Stalinist regime, but also of the still evolving identity of the Soviet population. There was therefore very little space in both public and private spheres where the labour experience abroad could be discussed. Ukrainians deployed to the Reich were marked upon their return/forced repatriation to the Soviet Union by the Communist Party

\footnotetext{
${ }^{12}$ The actual fate of returning Ostarbeiter was finally brought to light with the publication of Marta Dyczok, The Grand Alliance and Ukrainian Refugees (Houndmills: Macmillan Press Ltd, 2000). Approximately $7 \%$ of returning Ukrainian workers were sent to Gulags, far fewer than originally speculated.

${ }^{13}$ Grinchenko, "Oral Histories," 196.

${ }^{14}$ Gelinada Grinchenko, The shaping of remembrance: individual, group and collective patterns of memory of former Ukrainian Ostarbeiters, Beyond Camps and Forced Labour. Current International Research on Survivors of Nazi Persecution. Proceedings of the International Conference London, 11-13 January 2006, forthcoming, 2007), 2.
} 
with "the stigma of passivity," as Amir Weiner explains, and denied entry into the party. 15 "The stain of failing to rise to the occasion during the war was irremovable. With the polity as a whole realigned on the basis of wartime experience, the stigma was not only a party matter but a social one as well."16 The stigma of having worked in the Reich, regardless of whether one went voluntarily or forcibly, stayed with returnees and their offspring up until the collapse of the Union, denying one Party membership, the right to live in cities, and therefore, upward mobility. ${ }^{17}$ The experience of Ukrainian labourers in particular conflicted with the official Soviet memory of the war. The only version of memory that was permitted was that of patriotic resistance to the Nazi 'masters,' both organised, (e.g. example, involvement in partisan movements), and passive, (e.g. everyday sabotage on factory assembly lines). In Soviet-era collective studies and individual research papers, the forced labour of the Soviet population is considered just one of the numerous Nazi crimes against the occupied territories. ${ }^{18}$ A single thematic Russian- or Ukrainian-language study was consequently non-existent during the entire history of the Soviet Union.

It has only been since the collapse of the Union that Ukrainian and Russian interest in the experience has awakened, paralleling similar trends in the German- and English-speaking academic worlds. Among many changes since the end of the Cold War has been the gradual opening of formerly restricted state archives, which has resulted in a new depth of research into the topic. The volume of material being published in the

\footnotetext{
${ }^{15}$ Amir Weiner, Making Sense of War (Princeton: Princeton University Press, 2001), 8.

${ }^{16}$ Ibid, 84.

${ }^{17}$ Dyczok, The Grand Alliance and Ukrainian Refugees, 168.

${ }^{18}$ Grinchenko, "Shaping of remembrance," 4.
} 
former Soviet Union, however, is rather limited in comparison with that in the West. ${ }^{19}$ The first comprehensive study to be compiled on the post-Soviet territory was the Russian P. Polyan's Victims of Two Dictatorships: Life, Labour, Humiliation and Death of Soviet Captives and Ostarbeiter at Home and Abroad. ${ }^{20}$ Other works, mostly theses, are locally-focused and based primarily on the materials of regional archives. ${ }^{21}$ The first comprehensive forced labour study concentrating on the specific experiences of Ukrainians, in any language, was published by Grinchenko in $2004 .^{22}$ Her study employs a relatively new approach in scholarship on the post-Soviet territory - oral history. Through a series of interviews with 80 former Ostarbeiter and Polish-Ukrainian labourers, representing Ukrainians from different geographical areas, communities, gender and those active in social organisations, Grinchenko, for the first time ever, analyses not only the intricacies of Ukrainian experience in the Reich, but how the experience is remembered to this day. ${ }^{23}$

In the West, the use of foreign labourers in Nazi Germany was neglected in both the English- and German-speaking public and academic realms well into the 1980s. The only comprehensive study of Nazi foreign labour in either language before 1985 was the 1967 study by the American Edward Homze. ${ }^{24}$ His work is based on United States Strategic Bombing Survey studies, Nuremberg Trial documents, and source materials

\footnotetext{
${ }^{19}$ Due to my limited language skills in Russian and Ukrainian, I am dependent on the extensive work of Ukrainian historian Galinada Grinchenko (Kharkiv V.N. Karazin National University, Ukraine), in particular, her surveying of Ostarbeiter historiography in the post-Soviet territory.

${ }^{20}$ P. Polyan, Zhertvia dvukh diktatur: Zhizn', tprud, unizheniia i smert' sovetskikh voennoplennkh I ostarbayterov na chukhbne i na rodine( Moscow, 2002).

${ }^{21}$ Grinchenko, Shaping of Remembrance, 5 .

${ }^{22}$ Grinchenko, Gelinada. Nevygadane: Usni istorï octarbayteriv / Avtor-uporyad., red., vstup. St. X: (Vydavnychiy Dim 'Rayder,' 2004).

${ }^{23}$ As Grinchenko's study is only available in Ukrainian, I am dependent on two subsequent, to-bepublished English-language articles that discuss her original study, and further oral history projects: Oral Histories and Shaping of Remembrance.

${ }^{24}$ Edward Homze, Foreign Labor in Nazi Germany (Princeton: Princeton University Press, 1967).
} 
from Third Reich ministries. Homze focuses on the contradiction between ideology and foreign labour deployment, and the differences in national treatment. Although he largely underscores the role of the German population as an active force in Nazi foreign-labour policy, his study still stands as one of the best and most exacting investigations on the topic to date.

Further English-language scholarship since Homze's study is unfortunately limited. One exception is Karel Berkhoff's The Harvest of Despair, which explores how the Nazi occupation was experienced from the bottom-up by Ukrainians in Reichskommisariat Ukraine, German-occupied central and eastern Ukraine. ${ }^{25}$ In his quest to provide a glimpse into everyday life in occupied Ukraine, he focuses on the figures and people who had a daily impact, for example the native Nazi-controlled police force called the 'Schuma, ' who assisted with labour 'recruitment,' rather than Plenipotentiary General for Labour Deployment Fritz Sauckel, who led the recruitment and deployment schemes from Berlin. ${ }^{26}$ While he does indeed discuss the labour program, due to the geographical limits of his work, he does not cover the experience at German farms and factories. He does succeed at explaining the rationale for the program, how recruitment took place in occupied Ukraine, and how it was perceived by typical Ukrainians. English-language historians of modern Ukrainian history have been noticeably silent on the phenomenon.

\footnotetext{
${ }^{25}$ Karel C. Berkhoff, Harvest of Despair: Life and Death in Ukraine under Nazi Rule (Cambridge: Belknap Press of Harvard University Press, 2004).

${ }^{26}$ Schuma is the short-form for Schutzmannschaft, which roughly translates to 'Protection Force.' The Schuma in occupied Ukraine assisted with rounding up labour recruits, and with the Holocaust, amongst many other tasks.
} 
Comprehensive studies of Ukrainian history by Paul Robert Magocsi and Orest Subtelny make only passing mention of the use of Ukrainians as labourers in the Reich. ${ }^{27}$

The landmark German-language study on Nazi Germany's foreign workers is Ulrich Herbert's Fremdarbeiter, later published in English as Hitler's Foreign WorkersForced Foreign Labor in Germany Under the Third Reich, which began a flood of largely German-language literature when originally published in $1985 .{ }^{28}$ His figures set the broad consensus among scholars on the subject. In one of the few cases when Herbert discusses the peculiar situation of Ukrainians in the Reich, he states that regardless of whether they came from Galicia or Soviet Ukraine, Nazi officials classified all Ukrainians as 'Russians', thereby implying they received a rather unified level of treatment. As previously discussed, however, this was not true. Living and working varied depending on whether one came from the Generalgouvernement (Germanoccupied Poland) or the Reichskomissariat Ukraine (German-occupied Soviet Ukraine). Both Herbert and Homze make only passing mention to the specificity of the Ukrainian situation. They deal primarily with the history of foreign labourers in Germany, the regulations and policies guiding the entire foreign labour programme and how the program worked once implemented, detailing the conflicts that took place in the upper echelons of Nazi officialdom. Absent from their scholarship, however, is a discussion of how the program was experienced by the workers themselves. Both authors leave out the day-to-day lives of labourers in Germany, including how Ukrainians and other foreign labourers perceived and reacted to the experience. Their work, as well as most existing

\footnotetext{
${ }^{27}$ Subtelny, Ukraine: A History, 469; Paul Robert Magocsi, Ukraine: And Illustrated History (Toronto: University of Toronto Press, 2007), 280.

${ }^{28}$ Ulrich Herbert, Fremdarbeiter: Politik und Praxis des ,Ausländer-Einsatzes “ in der Kriegswirtschaft des Dritten Reiches. (Berlin: Verlag J.H.W. Dietz Nachf. GmbH, 1985) published in English as Hitler's Foreign Workers (Cambridge: Cambridge University Press, 1997).
} 
Western scholarship, tends to focus on the "extremes," with much attention given to the generous treatment of French and Dutch labourers relative to the starved Soviet POWs. Ukrainians, who were treated neither terribly well nor terribly poorly, have a largely untold story. The current study delves deeper into Herbert's sources, while relying on a more modern base of literature to examine the intricacies of how everyday life varied in the Reich for Ukrainians from the two jurisdictions.

Mark Spoerer's 2001 Zwangsarbeit unter dem Hakenkreuz (Forced Labour under the Swastika) was an attempt to bring together various scholarly articles and books on the theme, nearly fifteen years after the publishing of Herbert's first edition of Fremdarbeiter. ${ }^{29}$ Rather than an encyclopaedic reference book, Spoerer positions his volume as an introductory study on the entire forced labourer experience, and an overview of the innumerable regional and company histories published since $1985 . \mathrm{He}$ brings forth new features, including research on forced labour beyond the Third Reich Germany to the occupied countries of Europe, which also saw wide scale use of labour to serve the Nazi regime. He also provides a sketch of the compensation debate in Germany and Austria from July 2000. Drawing on a vast array of scholarship and research angles, Spoerer provides the most comprehensive examination of the unique situation of Ukrainians in the Reich. He brings to light where Polish and Soviet Ukrainians stood in the racial hierarchies, their legal status in the Reich, and discusses the mass reclassification of Polish Ukrainian and Soviet Ukrainian prisoners of war to civilian labourers, attributed to both racial and economic motives. Spoerer's discussion of Polish Ukrainians, in particular, has contributed significantly to the current study.

\footnotetext{
${ }^{29}$ Spoerer, Zwangsarbeit unter dem Hakenkreuz.
} 
German-language research into the deployment of foreigners in particular towns and cities of the former Third Reich is abundant, with most referencing Herbert's 1985 book as the ground-breaking study on the topic. Almost every metropolitan area and most towns in modern-day Germany have at least one archival finding aid or study of foreign labourers. ${ }^{30}$ Research into the various economic sectors in which Ukrainians and other foreigners worked is notable spotty and incomplete. The use of slave labour by Nazi big business is well-documented, with major studies, for example, on major automobile manufacturers Ford, General Motors, Volkswagen, Daimler-Benz, BMW, the Nazi-era chemical conglomerate IG-Farben, and in coal mines and shipping ports. ${ }^{31}$ On the contrary, the massive employment of foreign workers in German agriculture, households, municipalities and ecclesiastical institutions (monasteries, convents and parishes) has raised less interest in media and academia, and is often considered a marginal aspect of the labour program. This relatively weak interest in non-industrial fields can in part be attributed to the compensation programs created since the reunification of Germany and opening of the former Soviet Union. Large enterprises, focused during the war on the production of munitions and armaments, had large numbers of employees, thus making contemporary compensation claims relatively easier to process. In addition, many of the

\footnotetext{
${ }^{30}$ A few examples of urban/regional studies include the following works:Frank-Uwe Betz, Zwangsarbeit in Schwetzingen: Lager für ausländische Arbeiter zur Zeit des NS-Regimes (Pfaffenweiler: CentaurusVerlagsgesellschaft, 1998); Steffen Held and Thomas Fickenwirth, Fremd- und Zwangsarbeit im Raum Leipzig 1939-1945: Archivalisches Spezialinventar und historische Einblicke (Leipzig: Leipziger Universitätsverlag, 2001); Friederike Littmann, Ausländische Zwangsarbeiter in der Hamburger Kriegswirtschaft 1939-1945 (München: Dölling und Galitz Verlag GmbH, 2006). For a more extensive list, refer to the bibliography.

${ }^{31}$ Billstein, Working for the Enemy; Barbara Hopmann et. al., Zwangsarbeit bei Daimler-Benz (Stuttgart: Franz Steiner Verlag, 1994); IG Farben: Von Anilin bis Zwangsarbeit, (Stuttgart: Schmetterling Verlag, 1995); Hans Mommsen and Manfred Grieger, Das Volkswagenwerk und seine Arbeiter im Dritten Reich (Düsseldorf: ECON Verlag, 1996); Eckhard Schinkel, ed., Totaler Arbeitseinsatz für die Kriegswirtschaft: Zwangsarbeit in er Deutschen Binnenschifffahrt 1940-1945 (Essen: Klartext Verlag, 2005); Thomas Urban, Zwangsarbeit im Tagebau: Der Einsatz von Kriegsgefangenen und ausländischen Zivilarbeitern im mitteldeutschen Braunkohlenbergbau 1939 bis 1945 (Essen: Klartext Verlag, 2006); Constanze Werner, Kriegswirtschaft und Zwangsarbeit bei BMW (München: R. Oldenbourg Verlag, 2006).
} 
employing firms and companies exist to this day, and have the requisite financial resources to provide compensation. Weak interest can also be attributed to a lack of sources on the disparate experiences of foreigners deployed to agriculture, private households and municipalities. Academic research funding bodies are often more apt to provide funding to projects that have concentrated, archival source-bases, versus those that involve research that is decentralised.

Agriculture and private households, conversely, form a patchwork quilt of different working conditions and personal situations, which varied not only according to nationality and racial status, but also to the personalities of thousands of German families. A lack of pressing demand by agricultural and household employers to somehow "clear their names," combined with the variety of working and living conditions from one family to another has resulted in a scarcity of published materials. Compensation programs would be even more tedious and prolonged than those for industrial labourers, and frequently financially impossible for surviving family members. The forced employment of housemaids and nannies, to this end, is one of the most overlooked fields in the entire field of forced labour research. Ostarbeiter im Kinderzimmer (Ostarbeiter in Nurseries) exists as the first and only study into the employment of nearly 500,000 Byelorussian, Russian and Ukrainian girls in private German households. ${ }^{32}$ The author approaches the topic not as a trained social scientist, but rather as a German woman who grew up during the war with a nanny from the Soviet Union, and bases the entire study on a series of interviews conducted with Poles and Germans about the memories of working in the Reich or having an "Eastern" nanny. This

\footnotetext{
${ }^{32}$ Annekatrein Mendel, Zwangsarbeit im Kinderzimmer: "Ostarbeiterinnen " in deutschen Familien von 1939 bis 1945 (Frankfurt am Main: dipa-Verlag, 1994).
} 
study uses some of these stories, and together with the guiding Nazi regulations, paints a picture of a contradictory program that only loosely applied racial policies. The program saw members of one of Nazi Germany's most hated peoples, 'subhuman' Soviet citizens, deployed to the sacred German homestead.

This study relies on a rich pool of German- and English-language primary and secondary sources. Primary research is based mainly on a rich collection of documents from the Federal Archives of Germany, located in Berlin. The archive contains the documents of the Reich Labour Ministry (Reichsarbeitsministerium) and the Reich Main Security Office (Reichssicherheitshauptamt), which are of particular interest for the variety and breadth of issues relating to Ukrainian labourers. This study also relies on the documents of the Ukrainischer Hauptausschuss (Ukrainian Central Committee, Ukraïns'kyi Tsentral'nyi Komitet), which are held in the National Archives of Canada, and were published in $2000 . .^{33}$ The Ukrainischer Hauptausschuss was a Germanapproved relief committee that represented ethnic Ukrainians in the Generalgouvernement and did its best to speak, for Polish-Ukrainians employed in the Reich. Documents compiled for the International Military Tribunal at Nürnberg also serve as a useful source for this study. ${ }^{34} \mathrm{~A}$ variety of memoirs enhances an understanding of the Ukrainian labourer experience, published by labourers who immigrated to North America and Western Europe at the end of the war, along with summaries of interviews

\footnotetext{
${ }^{33}$ Wasyl Veryha, ed., The Correspondence of the Ukrainian Central Committee in Cracow and Lviv with the German Authorities, 1939-1944 (Edmonton: Canadian Institute of Ukrainian Studies Press, 2000), hereafter referred to as Ukrainian Central Committee.

${ }^{34}$ Der Prozeß gegen die Hauptkriegsverbrecher vor dem Internationalen Militärgerichtshof. Official text, German edn., vols. I-XLII (Nuremberg, 1947), hereafter referred to as IMT.
} 
with former Ukrainian labourers. ${ }^{35}$ These memoirs and interview summaries serve to flesh out the archival information. Research on the subject is supplemented by two personal interviews conducted by the author in 2005 , which are valuable in acquiring a feeling of significant features of life in Germany. ${ }^{36}$ Altogether, the labourers featured in the memoirs and interviews are in many ways representative of Ukraine at the time; an overwhelmingly agrarian society, with most of the population concentrated in Soviet Ukraine. ${ }^{37}$ Ranging in age from five to nineteen at the time of the war, the group represents a young generation of Ukrainians who grew up and were moulded in an environment of constant uncertainty and change. Their stories bring to life the labour experience as remembered through the eyes of the workers themselves. Postwar accounts can be problematic due to memory lapses and other historical inaccuracies, but the labourers here provided valuable information about and insight into their specific experience. This study uses the Nazi 'paper trail' as uncovered in the Bundesarchiv as a foundation, and inserts the voices of the workers into them to show the effects on the ground of a changing tone in Nazi racial policy.

It temporally precedes the work of Marta Dyczok, whose study The Grand Alliance and Ukrainian Refugees focuses on the post-bellum fate of approximately three million ethnic Ukrainians in the Third Reich, and their unique position in influencing

\footnotetext{
${ }^{35}$ Bill Basansky, Escape from Terror (Plainfield: Logos International, 1976); Billstein, Working for the Enemy; Antonina Khelemendik-Kokot, Kolkohz Childhood and German Slavery (Ukraine: n.p., 1993); Amy George and Al Janssen, Goodbye is not forever (Eugene: Harvest House Publishers, 1994); Elias Makuch, My Life Story (Unpublished personal memoir, held by Stephen C. Telka, 1997); Nina Markovna, Nina's Journey (Washington: Regnery Gateway, 1989); Vera Tkatschenko Siegmund, My Ukrainian Footprints (United States: s.n., c.1994).

${ }^{36}$ Fedir Telka, interview by Stephen C. Telka, 11 April 2005; Anonymous, interview by Stephen C. Telka, 11 April 2005.

${ }^{37}$ Berkhoff, Harvest of Despair, 7.
} 
Grand Alliance deliberations. ${ }^{38}$ It stands concurrently with Berkhoff's Harvest of Despair, shedding light on the lives of those Ukrainians forced to leave their occupied homeland, and with its focus infusing first-hand experiences into the official archival documents, complements Grinchenko's oral history project. And it goes into depth into the largest migration of the Ukrainian people, when many academics of Ukrainian history tend to cast it aside as simply a side-story of the war. ${ }^{39}$

This study is divided into three chapters. The first chapter discusses the origins of the foreign labour program, which trace its roots back to the Prussian use of Polish seasonal agricultural workers in the 1860s. The German experience with foreign labourers was further built upon during the First World War, which served as a base for the expanded use of foreigners during the Second World War, showing that although large in scope and scale, the Nazi Reichseinsatz was not entirely novel. The chapter also examines the ideological underpinnings of the treatment of Eastern Europeans in Nazi Germany, which was particularly harsh for those from the Soviet Union. The treatment of Ukrainian labourers in the Reich can similarly trace its roots back to the late nineteenthcentury and the First World War, in Germany's colonial experiences and ambitions in Eastern Europe. An understanding of these origins is critical to understanding the subhuman treatment that most ethnic Ukrainian labourers experienced in the Reich. An understanding of these origins also supports a novel discussion on why Polish Ukrainians

\footnotetext{
${ }^{38}$ Dyczok, Grand Alliance, 1; In addition to 2.4 million forced Ukrainian labourers, the German Wehrmacht, upon fleeing Red Army advances in Ukraine, ordered thousands of citizens to travel with them to the Reich. Included in this group were many who voluntarily chose to travel to Germany, to avoid Soviet reprisals for their work with the occupation authorities.

${ }^{39}$ Andrew Wilson, The Ukrainians: Unexpected Nation (New Haven: Yale University Press, 2000); Subtelny, Ukraine: A History, 469; Magocsi, Ukraine: An Illustrated History, 280.
} 
were treated differently than their Soviet counterparts, a topic yet to be explored by historians.

The second chapter addresses the major events surrounding the deployment of Ukrainians to Nazi Germany, and breaks them into three temporal phases. In tracking the major events that brought hundreds of thousands of ethnic Ukrainians to the Reich, one can also note how their deployment closely followed the war fortunes. It is therefore argued here that Nazi racial policy, especially as it pertained to Ukrainians, was much more fluid than often believed. As the war progressed, Nazi officials often relaxed or put aside National Socialist ideology for political and pragmatic reasons.

The third and final chapter focuses on the everyday experience of Ukrainian labourers in the Reich. It begins with the recruitment process in the Generalgouvernement and Reichskommissariat Ukraine, tracking their journey to Germany. It includes an in-depth discussion of conditions guiding deployment, accommodation/food/clothing, surveillance, and pay/labour rights, as well as an original exploration of free time activities for ethnic Ukrainians. The final part of the chapter is a case study of one kind of deployment in Germany, capturing the unique but often forgotten use of Soviet females as maids in German households. The case study shows the contradictions in Nazi racial policy, exploring a program that saw members of one of Germany's most hated 'races' tending the hearths and baby cradles for the most loyal of Nazi party members. Throughout the chapter, the major policy and regulation changes are tracked, and first-hand accounts are utilised to determine what sort of impact, if any, such changes had. Altogether, this study sheds some much-needed light on the oft-forgotten experience of the largest group of foreign labourers in Nazi Germany. 


\section{Chapter One - The Background and Foundation of Ukrainian Labour in Germany}

As the leader of a territorial and ideological war to assert incontestable dominance over the continent, all Axis war efforts fell under the aegis of the Germans. The responsibility for the production of arms, ammunition, vehicles and all war materiel strained the German economy, especially with the opening of the Eastern Front on 21 June 1941. The issue of manpower quickly became critical. Massive conscription of German men into the armed forces, the result of an expanded war mandate and increased battlefront deaths, left vast gaps in production and a soaring demand for labour. Even with the recruitment of ethnic Poles and Ukrainians plus Western, South-eastern and Northern Europeans from the occupied and allied territories between 1939 and 1941, German industry and farms still scrambled to meet production quotas. ${ }^{40}$ Infused with virulent racial ideology, but driven by a crippling labour shortage, the Nazi government expanded its extensive system of recruitment from occupied Europe to the newly acquired territories of the Soviet Union. Millions of citizens from the occupied areas of the East were 'recruited' from their hometowns, and deployed to the factories and farms of the German Reich.

Although the Reichseinsatz (Reich labour deployment program) was the most important instance of forced labour by foreign workers outside their home countries in the twentieth century, and was a critical aspect of the Nazi war machine, it was not a novel 'Nazi' concept, nor was it without precedent. Just as the roots of the Holocaust can be traced back to early twentieth-century colonial experience in German South-West

\footnotetext{
${ }^{40}$ Herbert, Hitler's Foreign Workers, 159.
} 
Africa, the roots of the Reichseinsatz can be found in the pre-First World War seasonal migration of ethnic Polish agricultural labourers to Prussia, and the use of prisoner-ofwar labourers of various nationalities during the First World War. ${ }^{41}$ These initial experiences with foreign workers, particularly with civilian Polish labourers, alongside colonial and racist attitudes set precedents for inferior levels of treatment for foreigners in Germany.

The second part of this chapter explores the Nazi ideology that informed the policies dealing with Ukrainian and other foreign labourers. This ideology similarly has its roots in Germany's First World War experience, in particular its colonial endeavours in the Occupied East, as well as anthropological projects on prisoners of war on the home front. ${ }^{42}$ The consequences of continuing industrialisation and urbanisation, combined with the post-war loss of the 'extra' breathing room it had acquired in Eastern Europe, gave Nazi ideologues the impression that the German 'race' was threatened. Nazi ideologues were influenced further by the "völkisch" (folkish) school of thought that called for people to return to the idealistic life in the countryside and driven by a purported need to find the German living space, or Lebensraum, to allow this movement to the countryside to take place. Hitler and other Nazi ideologues therefore set their sights on the vast territories of Eastern Europe, particularly the lands of the Soviet Union.

\footnotetext{
${ }^{41}$ For the link between the genocides in early twentieth-century German South-West Africa and Second World War Eastern Europe, see Jan-Bart Gewald, "Kolonisierung, Völkermord und Wiederkehr. Die Herero von Namibia 1890-1923, “ in Völkermord in Deutsch-Südwestafria. Der Kolonialkrieg (1904-1908) in Namibia und seine Folgen, ed. Jürgen Zimmerer and Joachim Zeller (Berlin: Links, 2003); Trutz von Trotha, "Genozidaler Pazifierungskrieg. Sozialogische Anmerkungen zum Konzept des Genozids am Beispiel des Kolonialkrieges in Deutsch-Südwestafrika 1904-1907,“ Zeitschrift für Genozidforschung 4.2 (2003); Joachim Zeller, "Symbolische Politik. Anmerkungen zur kolonial deutschen Erinnerungskultur" in Völkermord in Deutsch-Sïdwestafrika. Der Kolonialkrieg (1904-1908) in Namibia und seine Folgen, ed. Jürgen Zimmerer andn Joachim Zeller (Berlin: Links, 2003).

${ }^{42}$ For more on the German occupation of Eastern Europe during the First World War, see Vejas Gabriel Liulevicius, War Land on the Eastern Front (Cambridge: Cambridge University Press, 2001).
} 
The war also marked a shift in German anthropological tradition, from liberal to illiberal and from antiracist to racist, which would have a direct impact on ethnic Ukrainians. Echoing nineteenth-century Darwinist sentiments used to justify colonialism, National Socialist ideology held Ukrainians and other Eastern Europeans in low esteem: those from the Soviet Union were labelled 'subhumans,' or Untermenschen. Nazi foreign policy called for the elimination of the Soviet Union, the clearing from the Ukrainian and Polish lands of the native inhabitants, and the large-scale German colonisation of the entire region. They further referred to Darwinian ideas of race to prove the racial superiority of the Germans. The 'races' of Europe were therefore arranged and ranked according to Nazi racial and political criteria, thus dictating how they were to be treated during their time in the Reich. However, challenging concepts of race and ethnicity were ethnic Ukrainians, split between two racial-political groups, with those holding Polish citizenship receiving better treatment in the Reich than those from the Soviet Union. In addition to discussing Nazi ideology in regards to race and colonial policy and how it had an impact on Ukrainians, this chapter includes an original exploration of why ethnic Ukrainians from occupied Poland were favoured over Soviet Ukrainians, a situation that highlights the political dimension of the Nazi 'racial' hierarchy.

An understanding of the precedents to and background of the Reichseinsatz, and its Nazi ideological underpinnings is critical to the central argument of this paper, that the case of Ukrainian labourers speaks to the flexibility and limits of Nazi racial policy. In order to argue that the tone of anti-Slavic racial ideology changed with the course of the war, one must understand how the ideology came into being, and what precisely Hitler and Nazi ideologues presented as their vision for Germany vis-à-vis Ukrainians in the 
new German East. In tracing the roots of the labour program and German views of the East and its people to the First World War, it is also possible to see the ideology and subsequent actions of the Nazi regime not as an historical anomaly, but as part of greater movements and changes in Europe in the early twentieth century.

\section{I: The First World War: the Foundation of Nazi Labour Policy}

Before Nazi officials considered the idea of bringing Ukrainians and other Europeans to work in Germany, Polish seasonal labourers were employed on farms throughout Prussia. As this first section will discuss, the Reichseinsatz traces its roots to German experiences with foreign labourers as far back as the late nineteenth century, when Polish agricultural workers toiled on German farms. The First World War saw the deployment of prisoners-of-war from various enemy states mostly in agriculture, which Nazi war planners would look back on as a largely successful experience. Nazi plans for the spread of conflict across the European continent therefore called for the continued use of Polish agricultural workers, along with general prisoners-of-war, whose treatment was determined by Nazi ideology. The sheer size and extent of the program that eventually developed, however, was never planned for or anticipated. Similar to the twisted, unclear path that led to the genocide of Europe's Jewish population, the program that brought millions of foreign nationals from across the continent to the heart of the German Reich was a reactionary, often hasty process; an attempt to meet both ideological and wartime production needs and aims, while responding to the changing fortunes of a war with battlefields spread across an entire continent. 
The popularity amongst Prussian estate owners of using Polish seasonal labourers rose steadily beginning in the $1860 \mathrm{~s}^{43} \mathrm{~A}$ weak economy and depressed living standards in Russian-controlled Congress Poland forced many farmers to seek seasonal employment just over the border in the Prussia. ${ }^{44}$ Estate owners were more than happy to deal with a seemingly bottomless pool of workers, who did not strike, did not demand treatment en par with German farmhands, and were almost expendable. With the 1891 implementation of the Karenzzeit (closure period), Polish farmhands were forced to return to their homestead after the harvest. However, this soon changed with the increased production demands of the First World War, and through a variety of legislation and regulatory changes, Poles were forced to stay in Germany. The situation of Polish workers in Germany during this conflict foreshadowed the situation of Poles, Ukrainians and other Eastern Europeans twenty years later during the Second World War. $^{45}$ The Nazi deployment and maltreatment of civilian Poles and other Eastern Europeans was therefore not without precedent.

Furthermore, the employment of 1.1 million prisoners-of-war from such enemy states as Russia, France, Rumania, and Italy during the First World War was also deemed a generally positive experience by German officials. Despite problems with policing and security, low output and questions about how to punish the workers for bad behaviour as the International Red Cross and foreign consuls looked on, the German point-of-view

\footnotetext{
${ }^{43}$ On a history of the migration of Polish workers to eastern Germany as seasonal labourers, see Johannes Nichtweiss, Die ausländischen Saisonarbeiter in der Landwirtschaft der östlichen und mittleren Gebiete des Deutschen Reiches von 1890-1914 (Berlin, GDR: Rütten und Loening, 1959).

${ }^{44}$ Germany did not exist as a unified state until 1871 . Until that time, Prussia was the largest German principality.

${ }^{45}$ It is unlikely that substantial amounts of ethnic Ukrainians worked in Germany alongside ethnic Poles before or after the First World War. The Polish territories before WWI were divided between AustroHungary, Prussia and Russia. Galicia, home to the largest Ukrainian population of all Polish lands, was part of Austria-Hungary. Ukrainians there were more apt to emigrate to North America, than become seasonal labourers in Germany.
} 
was that the overall cost-benefit ratio was quite favourable. ${ }^{46}$ Experience employing civilian workers from beyond Poland, on the other hand, proved rather disappointing. Attempts, for example, to bring industrial workers from Belgium to fill vacancies created by conscripted German men met international protest. ${ }^{47}$ Belgians were backed by a broad national solidarity movement and assistance from abroad, making their employment in Germany very delicate. Poles, on the other hand, lacked a unified state, a united national front against the occupying power on the Polish territories, and a comparably keen international interest in the fate of Polish workers. Anti-Polish racism which predated the war meant that both German officials and the public viewed the repressive treatment of Poles as quite appropriate and normal. ${ }^{48}$

It was not the Nazis who invented such harsh measures as compulsory badges for Poles, imprisonment as a punishment for refusing to work, docking of rations, special policing legislation, maltreatment, armed guard units, and housing in fenced camps, which characterised the labour experience for Poles and other Eastern Europeans during the Second World War. Rather, such measures were already in practice, or at least envisaged, back in $1915 .^{49}$ Two trends from the WWI experience with foreign labour that were repeated after 1939, as will be discussed further, were a racist bias against workers from the East, along with an inherent oppressiveness by the authorities in the implementation of legislation. It was the systems of control, informed by racist thinking, that would have the greatest impact on labour policy against Ukrainians.

\footnotetext{
${ }^{46}$ Herbert, Hitler's Foreign Workers, 18.

${ }^{47}$ Gerhard Ritter, Staatskunst und Kriegshandwerk, vol. 3 (Munich: R. Oldenbourg, 1966), 448.

${ }^{48}$ Herbert, Hitler's Foreign Workers, 24.

${ }^{49}$ Ibid, 26.
} 


\section{I: Pre-war Labour Shortages and Solutions in Poland}

With the 30 January 1933 Nazi takeover of German governing power in the midst of one of the most economically pressing times for Germany, Hitler initiated plans for massive construction and re-armament programs, not only to get Germans employed, but also to prepare the country for war. With the commencement of the Four-Year-Plan in 1936, agricultural and industrial leaders were already reporting massive labour shortages. Between 1936 and 1939, the agricultural sector was most severely hit by the economic upswing, as rural Germans flocked to urban areas in search of better pay and new opportunities. In 1938, for example, a shortage of 250,000 workers was reported in agriculture. ${ }^{50}$ With full employment, and without the input of new labour, it appeared that Nazi Germany's goal of self-sufficiency was nothing more than a so-called 'pipe dream.' During these pre-war years, Germany essentially had three options to solve the labour issue. Firstly, it could halt armaments production, which would have meant an end to the war policy so central to Nazi power. Secondly, it could make existing labour more intensive and effective, or thirdly, it might absorb new workers from untapped reservoirs. Deploying the "female labour reserves" of Nazi Germany was out of the question, based on Nazi ideological grounds, although German girls under 25 had to provide an obligatory year of service as housemaids or farmhands. Attempts to increase labour productivity had only limited results, but experience with adding workers from different sources would prove fruitful. ${ }^{51}$ The answer to Germany's labour problems would become clearer with the 1938 annexations of Austria and the Sudetenland of Czechoslovakia. The annexations brought army supplies, industrial capacity and reserves of gold and cash, as

\footnotetext{
${ }^{50}$ Timothy W. Mason, Sozialpolitik im Dritten Reich (Opladen: Westdeutscher Verlag, 1977), 167.

${ }^{51}$ Herbert, Hitler's Foreign Workers, 36-41.
} 
well as the labour energy of thousands of Czechs, Austrians and Sudetenland Germans, who were mobilised to the needs of the war machine. Despite the influx of new labour, Poles still comprised the largest group of foreigners working in the Reich.

By the end of 1938, there still existed a shortage of one million workers in the Reich, yet plans for the large-scale recruitment of foreign civilians were far from sight. ${ }^{52}$ Rather, the Nazi state tackled the labour shortage with three approaches. Firstly, holes in the labour market would be plugged by small-scale deployment of Czechs, Austrians and Volksdeutsche, leaving German women at home. Secondly, territorial expansion would be used to side-step currency issues with workers sending remittances home, which was draining German foreign currency reserves and therefore war finances. Lastly, it was hoped that the manpower problem would simply solve itself through the deployment of prisoners-of-war as during the First World War. Quick military victories would also bring released German soldiers home quicker, negating the need to employ foreigners longterm in the heart of the German nation. Civilian and military Poles would certainly be relied upon to shoulder the bulk of the labour demands, but not in the millions, as would later be the case. "The decisive question was whether or not they wanted foreigners to work in Germany at all," explains foreign labour historian Herbert. "Once that decision (officially labelled a temporary stopgap) had been reached, the process of deployment (based on the tradition of legal and social discrimination against Polish farm workers in particular) became progressively harsher," and eventually, "led at an ever quickening pace toward mass forced labour." 53 This tradition of legal and social discrimination of labourers from Eastern Europe can be traced back to the seasonal employment of Polish

\footnotetext{
${ }^{52}$ Labour Ministry to head of Reich Chancellery, 17 December 1938 in Mason, Arbeiterklasse und Volksgemeinschaft, p.857-8.

${ }^{53}$ Herbert, Hitler's Foreign Workers, 59-60.
} 
agricultural hands in late nineteenth-century Prussia, which found them working long hours without legal protection and state benefits. Combined with German experiments with prisoners-of-war during the First World War, and severe labour shortages in the overheated German economy of the 1930s, the stage was set for a large-scale deployment of Ukrainian and other foreign labourers in the Reich.

\section{II: German Policy in the East: Lebensraum and Untermenschen}

What made Nazi Germany's Second World War foreign labour deployment program unique from previous schemes to bring foreigners to work in Germany was not only the scope and scale of the program that eventually came into being, but also the severe Nazi ideology that imbued policy and regulation decisions, which directly influenced the living and working conditions of Ukrainians deployed in the Reich. As the second half of this chapter discusses, both Polish and Soviet Ukrainians, along with many other Eastern Europeans, were marked before the war for assimilation or extermination in one form or another. As is the case with most nineteenth- and twentieth-century colonial relationships, the Drang nach Osten (push eastward) in search of Lebensraum was accompanied by undertones of Social-Darwinism and cultural arrogance, backed up with purportedly 'scientific' proof. ${ }^{54}$ This section argues that just as the Nazi use of foreign forced labourers can be traced back to the First World War, so too can the policies and ideology that justified Nazi Weltanschauung (world view) and their Drang nach Osten. German experiences during the Great War would have a direct influence on the treatment of ethnic Ukrainians more than twenty years later. Although the policies and regulations that the Nazis later developed concerning ethnic Ukrainians in the Occupied East and the

\footnotetext{
${ }^{54}$ Herbert, Hitler's Foreign Workers, 69.
} 
Reich were based on racist and colonially-minded ideology, the actual implementation and end treatment of Ukrainian labourers shows its inherent flexibility. And as the next chapter shows, Nazi officials were willing to relax or ignore aspects of party ideology to respond to the broader political situation and the fortunes of the war. ${ }^{55}$

Both the Reich Main Security Office (Reichssicherheitshauptamt) and Reich Propaganda Ministry (Reichspropagandaministerium) used the term Untermensch to describe the 'sub-human' populations of Eastern Europe, which consisted primarily of Soviet citizens, Jews, Roma and Sinti, and published brochures dealing with how they were to be treated. ${ }^{56}$ The desire to acquire Lebensraum and clear it of the inhabitant Untermenschen, a throw-back to nineteenth-century European colonialism, meant that the 'subhumans' inhabiting the German living space, comprising most ethnic Ukrainians, were placed in the bottom rungs of the racial-political hierarchy, and treated amongst the worst of foreign labourers. The concepts of space and race, therefore, became intrinsically linked. ${ }^{57}$ However, as previously mentioned, Ukrainian labourers originated from two separate pre-1939 states, and were afforded differing treatment. While the precise differentiation of treatment is explored in depth in the third chapter, this section includes a discussion of why political determinants became more influential than ethnicity when dealing with Ukrainian labourers.

The First World War had a great impact, firstly, on German anthropology, and how Germans viewed themselves vis-à-vis the European and non-European 'Other.' As

\footnotetext{
${ }^{55}$ The best example of the official relaxing of Untermensch policy is the May 1943 changes to Ostarbeiter deployment. See Circular letter from Party Chancellery, 5 May 1943, Doc 205PS IMT Vol.25, pp.298.

${ }^{56}$ Domenico Losurdo, "Toward a Critique of the Category of Totalitarianism", Historical Materialism 12.2 (April 2004): 50.

57 Jürgen Zimmerer, "The birth of the Ostland out of the spirit of colonialism: a postcolonial perspective on the Nazi policy of conquest and extermination," in Colonialism and Genocide, ed. A. Dirk Moses and Dan Stone (London: Routledge, 2007), 106.
} 
Andrew D. Evans argues, it was during the Great War that German anthropology "saw a radical break between the liberal and often antiracist anthropological science of the nineteenth century and the illiberal, racist anthropology of the twentieth."58 German and Austrian anthropologists, motivated by the potential to study African, Indian and Asian troops pouring into prisoner of war camps on German territory, soon found themselves studying Germany and Austria-Hungary's European enemies as racial 'Others.' Anthropological studies by Rudolf Pöch and Egon von Eickstedt, in particular, classified most citizens of the enemy Russian Empire as non-Europeans, with graded similarities to Mongolians. ${ }^{59}$ On the other hand, those within the boundaries of the Austro-Hungarian Dual Monarchy, including the mixed Polish-Ukrainian province of Galicia, were not subject to examination, an attempt to emphasise the unity of that Empire. The common consensus of German anthropology moved from a strict separation of race, nation and Volk that characterised the field twenty years earlier, to that of Rassenkunde, the overtly racist brand of "racial science" found already in France and the United Kingdom. 60 Germans and other Nordic peoples were now defined by anthropologists as a 'race,' with distinctions drawn between Slavs within Austria-Hungary and those further East. These ideas were later harnessed to a political party willing to root out any and all forms of the 'Other' within its growing geographical boundaries, and give the terms Unter- and Übermenschen (sub- and superhumans) everyday meaning.

\footnotetext{
${ }^{58}$ Andrew D. Evans, "Anthropology at War: Racial Studies of POWs during World War I," in Wordly Provincialism: German Anthropology in the Age of Empire, ed. H. Glenn Penny and Matti Bunzi (Ann Arbor: University of Michigan Press, 2003), 198.

${ }^{59}$ Ibid, 224.

${ }^{60} \mathrm{Ibid}, 226$; See also Robert Proctor, "From Anthropologie to Rassenkunde in the German Anthropological Tradition," in History of Anthropology vol. 5 - Bones, Bodies and Behavior: Essays on Biological Anthropology, ed. George W. Stocking, Jr. (Madison: University of Wisconsin Press, 1988), 138-179.
} 
The German military and colonial experience in Eastern Europe during the First World War also altered how Germans saw their role there, and thus influenced Nazi plans during the Second World War. As Vejas Gabriel Liulevicius explains, based on unsuccessful attempts to colonise and reshape the lands of the Balts, Poles and Ukrainians on a German model, the Great War experience resulted in a change of thinking in terms of the Eastern spaces. The territories were seen no longer seen by German military planners in terms of "Land und Leute" (lands and peoples) with history and internal coherence, as had been the case upon entering them, but rather as an empty, unorganised "Volk und Raum" (race and space), denoting an ahistorical, "scientific" space, stretching to the eastern horizon, "to be ordered by German mastery and organisation." ${ }^{, 61}$ Coinciding with this change of thinking on the East was the growing popularity in Germany of folkish (völkisch) ideology, following the movement to establish utopian settlements in England and the United States. ${ }^{62}$ Supporters of folkish ideas believed that a national discord had risen because of class conflicts in an industrial society, political rivalry among the parties, and unemployment due to a dependence on world markets. They posited that such problems could be avoided by a properly balanced relationship among the individual, the community (Gemeinschaft), and the land. For them, the peasant community became the ideal locale of a healthy society, in which each citizen was entitled to land and communion with the soil. ${ }^{63}$ Friedrich Ratzel's 1901 essay

\footnotetext{
${ }^{61}$ Wendy Lower, Nazi Empire-Building and the Holocaust in Ukraine (Chapel Hill: University of North Carolina Press, 2005), 21; For a discussion of Raum, see Liulevicius, War Land on the Eastern Front, 2523

${ }^{62}$ Wendy Lower, "A New Ordering of Space and Race: Nazi Colonial Dreams in Zhytomyr, Ukraine, 1941-1944," German Studies Review 25-2 (May 2002): 21.

${ }^{63}$ Ihor Kamenetsky, "German Colonization Plans in Ukraine during World Wars I and II," in GermanUkrainian Relations in Historical Perspective, ed. Hans-Joachim Torke and John-Paul Himka, (Edmonton: Canadian Institute of Ukrainian Studies Press, 1994), 99-100.
} 
on Lebensraum captured these ideas, and were given a racial twist, connected with the existential problems of common man and a geopolitical expansion eastward by Karl Haushofer, founder of the University of Munich's Institute of Geopolitics in $1924 .{ }^{64}$ It was during Adolf Hitler's stay at the Landsberg prison, during which he wrote his semiautobiographical text Mein Kampf, that Hitler absorbed these ideas, and made them a critical part of his party's platform and plans for the salvation of the German nation.

While the racist ideas and thoughts that drove the National Socialist Party were not unique to Germany, the enthusiasm and zeal in which they were implemented into the Nazi every day certainly were. Nazi Party leader Adolf Hitler's Mein Kampf, which loosely laid out National Socialist plans in the East, attacked the presence of Jews on the European continent, while proposing an eastern expansion of the German Empire into the territories of the Soviet Union. Growing eastward would solve two perceived problems. Firstly, it would usher in the destruction of the mammoth 'Jewish-Bolshevik' state, Germany's largest and most rapidly developing enemy, which Hitler believed was a Semitic creation. According to Hitler, "this colossal Empire in the East is ripe for dissolution:" "the end of the Jewish domination in Russia will also be the end of Russia as a State. We are chosen by Destiny to be the witnesses of a catastrophe which will afford the strongest confirmation of the nationalist theory of race." ${ }^{\circ 5}$ In bringing about the destruction of Russia, Germany would then have a free hand in moulding and developing its vast territories.

\footnotetext{
${ }^{64}$ Kamenetsky, "German Colonisation Plans," 99-100.

${ }^{65}$ Adolf Hitler, Mein Kampf, (Hurst and Blackett Ltd, 1939), http://gutenberg.net.au/ebooks02/0200601.txt (accessed 27 June 2008).
} 
The Russian lands were critical to solving Germany's second perceived problem, a shortage of space. According to Hitler, in order for the German nation to survive, grow and prosper, German people needed Lebensraum, or living space.

The struggle for the hegemony of the world will be decided in favour of Europe by the possession of the Russian space. Thus Europe will be an impregnable fortress, safe from all the threat of blockade...The Slavs are a mass of born slaves, who feel the need of a master...The Russian space is our India. Like the English, we shall rule this Empire with a handful of men...We'll supply the Ukrainians with scarves, glass beads and everything that colonial peoples like...In any case, my demands are not exorbitant. I'm only interested, when all is said, in territories where Germans (Germanen) have lived before. The German people will raise itself to the level of this empire. ${ }^{66}$

This view of Eastern Europe as a colonial space was not novel, but was based on the experience during the First World War. "When we speak of new territory in Europe today," Hitler wrote, "we must principally think of Russia and the border States subject to her. ${ }^{967}$ Soviet Ukraine, as the largest subject border state, was therefore at the top of the list of desired war proceeds in the East. Hitler imagined the Nazi Lebensraum in the East as a "flourishing park landscape of Germanic types," where the inhabitant ethnic Germans, descendants of Goths, would provide raw materials and new blood for the new Empire. ${ }^{68}$ Nazi officials, furthermore, pined for the fertile black steppe of Ukraine, viewed as a plentiful "European California", and although poorly used under the 'subhuman' Slavs, would be developed as the bread-basket of the German Reich. ${ }^{69}$ In this new colonial relationship with the East, the native populations would be turned into a

\footnotetext{
${ }^{66}$ Adolf Hitler, Hitler's Table Talk, 1941-1944, ed. Hugh Tervor-Roper (Oxford: Oxford UP, 1988), $32-5$.

${ }^{67}$ Hitler. Mein Kampf, e-book.

${ }^{68}$ Lower, "New Ordering of Space," 227.

${ }^{69}$ Nationalsozialistische Deutsche Arbeiter-Partei Reichsführer-SS, Der Untermensch (Berlin: Vertrieb Nordland Verlag, 1942).
} 
cheap labour force, supporting thousands of German settlers who would be brought into the region to cultivate and civilize it.

Seventeen years after the first edition of Mein Kampf, and nine years after the National Socialist party took control of the German state, Nazi colonial plans took shape in Soviet Ukraine, occupied by Nazi troops following the May 1941 invasion.. Heinrich Himmler, the Reich Leader of the SS and Commissioner for the Strengthening of the Germanic Race, spoke on 16 September 1941 before a gathering of SS and Police leaders at his Ukrainian field office, explaining that, "[t]his Germanic East extending as far as the Urals must be cultivated like a hothouse of Germanic blood." His vision was for an SS enclave of ethnic Germans and Volksdeutsche near Vinnytsia with the idyllic title of Hegewald. $^{70}$ The German expansion into the East would be administered by Reichsdeutsche (Germans from the centre of the Reich) trained in the geography and socio-cultural history of the Ukrainian territories. Berlin's Ukrainisches Wissenschaftliches Institut (Ukrainian Scientific Institute), affiliated with Friedrich Wilhelms University, appeared poised to churn out trained administrators, organising courses, language classes, and a variety of lectures and special events throughout its existence in the pre-war years. ${ }^{71}$ They would be the flag carriers of Germany's eastward expansion, and with the new settlers, would ensure the future of the nation. As historian

\footnotetext{
${ }^{70}$ Lower, "New Ordering of Space," 227; For more on Hegewald, and occupied Vinnytsia, see Kate Brown, A Biography of No Place (Cambridge, Harvard University Press, 2003).

${ }^{71}$ BArch NS 43/43, fol.186; The exact number of Reichsdeutsche occupation officials trained at the Institute is unknown, but is presumed to be small, based on the relatively small size of the institute and the vastness of the Ukrainian territories that were administered by Germans. Further research into the Institute is required; Friedrich Wilhelm University, located in East Berlin after the division of the German capital into four zones of occupation by the Allies, had its name changed in 1949 to Humboldt University by the ruling (communist) Social Unity Party of Germany (Sozialistische Einheitspartei Deutschlands).
} 
Wendy Lower has characterized it, “Germany's socio-political ills would be resolved by eliminating her racial enemies, namely the Jew., ${ }^{, 72}$

In order to classify, order and rank the peoples of Europe, a system of Nazi 'racial' stereotyping was developed and introduced that was based on the German experience with classifying prisoners of war during the First World War. The Nazis also intended to make up for the purported shortcomings of traditional notions of race that failed to take into consideration political and historical divisions. These racial stereotypes, translated into a hierarchy, and given life through legislation, decrees and regulations, would come to impact the everyday lives of Ukrainian and other foreign workers deployed in the Reich. Most Ukrainians and other fellow Soviet citizens were labelled 'sub-human' and in the minds of party officials and many citizens, retained a subordinate status up until the end of the war. Galician Ukrainians, while marginally better off, still faced anti-Slavic prejudices, and were marked with Poles and other "Eastern" nations in the Generalgouvernement (German-occupied Poland) for assimilation and elimination. ${ }^{73}$

In his 28 May 1940 "Thoughts on the Handling of the Foreign Peoples in the East," Himmler laid out how Polish Ukrainians and other residents of the Generalgouvernement were to be treated, plans later approved by the Führer himself. ${ }^{74}$ The population would initially be divided and splintered along ethnic lines as much as possible, and minority populations would be favoured through appointments over the majority populations. Ethnic Ukrainians, comprising totalling 4.4 million or $14 \%$ of the

\footnotetext{
${ }^{72}$ Lower, "New Ordering of Space," 228.

${ }^{73}$ Brown, Biography of No Place, 206.

74 "Denkschrift Himmlers über die Behandlung der Fremdvölkischen im Osten," 28 May 1940, BArch NS 19/1737.
} 
population, were to receive preferential treatment over the majority ethnic Poles, who totalled 22 million or $70 \%$ of the population. ${ }^{75}$ This was a German 'divide-and-rule' occupation strategy that aimed to tap into discontent over decades of life under the oppressing Poles, win over Ukrainians to the German cause, and further weaken the Polish national body. ${ }^{76} \mathrm{SS}$ officials would screen the population for "racially reliable" members, who would be sent to the Reich to be assimilated, with the end goal of reducing the size of the non-German population. ${ }^{77}$ By 1944 , five years after the Nazi defeat of Poland, the term 'Kashubian' would be unknown, for example, as the German state would have assimilated the group out of existence. ${ }^{78}$ Nazi plans in the East similarly foresaw the elimination, through assimilation and starvation, of the ethnic Ukrainian population. The document called for the elimination of the 'term' Ukrainian, which would come about through the massive assimilation of germanisiable elements. Ukrainians as a distinct ethnic group, Himmler wrote, "would take a greater amount of time to eliminate, but [their] elimination would indeed be possible." ${ }^{, 79}$ It is therefore clear that even before plans were drawn up to deploy Polish and Soviet Ukrainians to farms and factories across the Reich, they were already discriminated against and targeted for elimination as an ethnic group.

\footnotetext{
${ }^{75}$ Spoerer, Zwangsarbeit unter dem Hakenkreuz, 44. After Ukrainians, the largest ethnic groups in Poland (as of the 1931 census) were Jews, totaling 2.7 million or $9 \%$ of the population, and Byelorussians, with 1.7 million and $5 \%$ of the population.

${ }^{76}$ For more on Nazi occupation policies in Occupied Poland, see Marek Jan Chodakiewicz, Between Nazis and Soviets: Occupation Politics in Poland, 1939-1947 (Lanham: Lexington Books, 2004).

${ }_{77}^{7}$ For more on Nazi plans to racially screen the native population, see Brown, A Biography of No Place, $192-225$.

78 "Denkschrift Himmlers über die Behandlung der Fremdvölkischen im Osten," 28 May 1940, BArch NS 19/1737; The Kashubians are a West-Slavic ethnic group, found in north-central Poland, and centred mostly around Gdańsk.

${ }^{79}$ Ibid.
} 
To further hinder the full development of ethnic nationals in Occupied Poland, Himmler declared that education would be reduced to elementary skills, and instruction would concentrate on counting until 500, writing one's name, understanding it is "a Godgiven order to be obedient to the Germans," and being honest and hard-working. "Reading I don't see as necessary," he wrote ${ }^{80}$ Himmler also foresaw a system to racially screen the youngest Eastern Europeans. Children aged 6 to 10 would be screened yearly at school, using unspecified criteria, and based on the vague "worthiness" of their blood, could be shipped to the Reich, where they would be given German names and brought up as 'true' Germans. ${ }^{81}$ Education did not serve as a means to change one's race. Rather, schools served as a common location to evaluate how the children had developed given the same educational 'inputs,' revealing which of the Ukrainian, Byelorussian and Polish children were actually suitable for assimilation. This policy marked an inherent flexibility and openness in Nazi racial policy vis-à-vis ethnic Ukrainians from the Generalgouvernement. Although the Nazi policy was ideologically driven, it left room for political considerations and a level of pragmatism in determining who was permitted to assimilate.

Telling of the treatment that other non-German inhabitants of the Generalgouvernement could expect, the document called for all remaining "unworthy" Poles, Ukrainians and other Slavs, to be joined by other "unworthy" peoples from other parts of the Reich (eg. Sorbs and Fends), and become a leaderless "working people." They would be mobilized as migrant workers, coming to the Reich yearly to work on

\footnotetext{
80 "Denkschrift Himmlers über die Behandlung der Fremdvölkischen im Osten," 28 May 1940, BArch NS $19 / 1737$

${ }^{81}$ Ibid.
} 
special major building projects like stone bridges, roads and buildings. ${ }^{82}$ They would have "more to eat and live on than under Polish rule," and work in the Reich under the "strict, consistent and just management of the German people." Such plans to have Eastern Europeans working the Reich were not novel. By May 1940, when the document was released, thousands of ethnic Poles and Ukrainians were already working in the Reich, mostly in agriculture. What the document did was confirm a colonial, subservient role for those inhabitants of the Generalgouvernement not deemed racially reliable, in particular, the use of Eastern peoples for heavy labour in the Reich. And while the German policy in the Generalgouvernement assumed a certain level of racial affinity with some Polish Ukrainians and other Slavs, as seen with the possibility of assimilation, the policy further East on the territory of the Soviet Union was more racially charged. Soviet Ukrainians and other Soviet citizens were viewed by Nazi ideologues as inhabiting the future Lebensraum of the German nation, and therefore seen much differently than Polish Ukrainians. In order to clear the land for German colonisation, and in a process similar to colonial policy in German South-West Africa, Nazi plans called for the mass starvation of at least 30 million of the native inhabitants. ${ }^{83}$ Remaining inhabitants would be used to assist the Germans in the eastward expansion of their empire, maintaining agricultural output levels until German farms were operational, at which time they would be deemed surplus, and most likely eliminated. This was justified on loose Darwinian theories that purported Slavs, particularly Soviet citizens, to be racially inferior, or 'subhuman.'

\footnotetext{
${ }^{82}$ The Sorbs are an ethnic group related to the Serbs, and found primarily between the Spree and Neisse River (along the modern Polish/German/Czech Republic borders). The group, like the Fends, was persecuted by the Nazi regime, and marked for assimilation and elimination.

${ }^{83}$ Spoerer, Zwangsarbeit unter dem Hakenkreuz, 71.
} 
The taking of nearly three million Soviet prisoners of war by 15 October 1941, and the relatively speedy winning of the Soviet Republics of Ukraine and Belarus less than four months after the commencement of the attack on the Soviet Union, became a welcome illustration of Eastern inferiority for German propaganda, and a justification for German policy in the East. The prisoners, and by implication all Soviet men, were described in one account as "a mixture of low and lowest humanity, truly subhumans." Another writer, commenting on the conduct of Soviet soldiers during war, explained, "He fights when all struggle is senseless. He fails to fight, or fights quite wrongly, where there is still a chance of success." ${ }^{, 85}$ The fifty-page, 1942 publication Der Untermensch, prepared, illustrated and distributed by the SS, sought to demonstrate the inferiority of the "Eastern criminals," playing up contrasts between degenerate Easterners and the clean, healthy Nordic Germans. ${ }^{86}$ Distributed at the same time that thousands of Soviet citizens were being shipped to the Reich on a daily basis, the booklet sold at news stands for months, and was widely circulated among the German population. ${ }^{87}$ The booklet opens with a 1935 speech by Himmler in which he theorizes, "as long as humans have lived on Earth, there has been a battle between humans and sub-humans." Used in the booklet, it seems to justify the attack on the Soviet Union as simply, "part of the normal course of events on our planet." ${ }^{, 88}$ The largely visual publication juxtaposes contrasting photographs of Untermensch (essentially Soviet) and European (mostly German) houses, churches, children, artwork, factories and armies, showing the inherent backwardness and squalor of the Soviet citizens, versus the ideal, quintessential Germans. "The Soviet

\footnotetext{
${ }^{84}$ Alexander Dallin, German Rule in Russia (London: MacMillan \& Co., Ltd., 1957), 69.

${ }^{85}$ Dallin, German Rule in Russia, 69.

${ }^{86}$ Reichsführer-SS, Der Untermensch.

${ }^{87}$ Dallin, German Rule in Russia, 70.

${ }^{88}$ Reichsführer-SS, Der Untermensch.
} 
worker lives worse than a Bushman," explains the caption to a photo, showing workers' apartments with views to towering factories billowing black plumes. Under a photo of a Soviet farm, another caption reads, "In desolate holes that no longer deserve the name 'living space,' the people lead an animalistic existence." 89 The booklet makes no attempt to differentiate the various ethnicities of the Soviet Union, using the blanket definition of Untermensch for the entire population. Through such literature, Nazi ideologues clearly made a delineation in the eyes of the German public between a future subaltern, and the colonising, civilised German Übermenschen or "superior humans."

Another aspect of the booklet justified the eastward expansion of the Reich to a hesitant populace by invoking a colonial-style 'civilising mission.' However, the Nazi version of the civilising mission differed from earlier European efforts around the world. Rather than somehow creating gentlemen out of the uncultured masses through the transferring of culture to the 'natives,' Nazi plans for the Soviet Union foresaw the mass starvation of the native population to clear the land for German settlers who would themselves bring German civilisation.

Der Untermensch was by no means the only anti-Slavic publication that circulated. The first issue of the Wehrmacht propaganda series Mitteilungen an die Truppe in June 1941 spelled out the rules governing behaviour toward the enemy in the East in unambiguous terms:

Anyone who has ever looked into the face of a red commissar knows what Bolsheviks are. There is no further need for theoretical explanations. It would be an insult to animals to describe the features of these slavedrivers, a large percentage of whom are Jewish, as bestial. They are the embodiment of everything infernal, the incarnation of insane hatred for all that is noble in man. These commissars are the revolt of the subhuman

$\overline{{ }^{89} \text { Reichsführer-SS, Der Untermensch. }}$ 
[Untermensch] against nobility of blood. The masses, whom they hound to death using all the resources of cold-blooded terror and imbecilic incitement, would have brought about an end to all meaningful human existence - if their foray had not been foiled at the last minute. ${ }^{90}$

The mixing of racial with political ideas was clearly a common aspect of Nazi ideology. This was especially evident in occupied Soviet Ukraine, where the administration was known amongst the population for its brutality and ruthlessness. Erich Koch, the Reichkommissar (Reich Commissioner) for Reichkommissariat Ukraine was quoted as saying, "the attitudes of the Germans in the [Ukraine] must be governed by the fact that we deal with a people which is inferior in every respect... There must be no acts of sentimentality. This people must be governed by iron force, so as to help us to win the war now. We have not liberated it to bring blessings on the Ukraine but to secure for Germany the necessary living space and a source of food." ${ }^{.91}$

The opinion in the upper echelons of the Nazi regime on the issue of Ukrainian nationhood and separate treatment was for the most part unified, with slight variations in the carrying out of these plans held by the Minister in charge of the Eastern Territories. ${ }^{92}$ Alfred Rosenberg, who was appointed head of the Reich Ministry for the Occupied East only four weeks after the 22 June invasion, had long been a supporter of the Ukrainian nation and a distinct Ukrainian state. Brought up in Estonia, which had struggled itself against Russian and Soviet expansionism, he posited the enemy of Germany and Europe as the Great Russians. ${ }^{93}$ Rosenberg saw differences between the different Eastern European and Soviet nationalities, and room for the promotion of national movements.

\footnotetext{
${ }^{90}$ Herbert, Hitler's Foreign Workers, 140.

${ }^{91}$ Dallin, German Rule in Russia, 143.

${ }^{92}$ Kamenetsky, "German Colonization Plans," 101.

${ }^{93}$ Dallin, German Rule in Russia, 47
} 
He proposed support for Ukrainian nationalism and the creation of a Ukrainian state as a cordon sanitaire against Muscovy. ${ }^{94}$ However, Rosenberg's plans did not survive German officialdom, with Hitler and other party officials refusing any sort of national recognition in the east, viewing all nations as equally Untermensch and inferior to Germans. ${ }^{95}$ Ukrainians, as with most Easterners, were looked down upon from the heights of the Aryan-topped hierarchy. An understanding of this subhuman status in the eyes of Germans is vital to attaining a full understanding of the Ukrainian labourer experience. Nazi bureaucrats and leaders were imbued with Untermensch ideology, and saw them as inhabiting their Lebensraum, attitudes that pervaded policies and procedures on the treatment of Ukrainians.

\section{II:The Nazi Racial-Political Hierarchy}

Not all Ukrainians, however, were ranked the same in the Nazi racial hierarchy. I have already suggested that Ukrainians were considered subhumans by the Germans. Their placement near the bottom of the hierarchy was in part a product of the conviction that in terms of physical traits, political and historical background, they were further from the master race than other nations. It was on these grounds that Scandinavians, for example, were accorded a higher status than Poles. While Ukrainians formed a national group, with a common language, heritage, and physical characteristics, owing to their different upbringing under two political systems, they were considered two distinct groups by Nazi ideologues. As such, they were divided by the Nazis and placed at different planes in the hierarchy of foreign races. As shown in Figure 1, compiled by

\footnotetext{
${ }^{94}$ Ihor Kamenetsky, "German Colonization Plans," 101.

95 Dallin, German Rule in Russia, 122.
} 
Mark Spoerer by analyzing various government decrees and regulations, the top of the six-level hierarchy of foreign workers in Nazi Germany was occupied by the Italians (until 1943), along with fellow allied and neutral states Bulgaria, Croatia, Romania, Slovakia, Spain and Hungary. The placing of some Slavs on the top of the hierarchy, ahead of other Slavic groups, shows the way in which the Nazis often bended or sacrificed ideology to meet political aims. On the second level, and only minimally worse off in terms of wages, housing and working conditions, were workers from the occupied North, West and Southeast regions of Europe, including Norway, Denmark, the Netherlands, Belgium, France, the Protectorate of Bohemia \& Moravia, Serbia and Greece. Workers on these two top levels, at least on paper, received the same food rations and workers rights as their German colleagues.

\begin{tabular}{|c|c|}
\hline & $\begin{array}{l}\text { Fig. } 1 . \\
\text { The Hierarchy of Foreign Workers in Nazi Germany }{ }^{96}\end{array}$ \\
\hline 1. & $\begin{array}{l}\text { Workers from allied \& neutral countries: Italians (until 1943), } \\
\text { Bulgarians, Croatians, Romanians, Slovakians, Spaniards \& } \\
\text { Hungarians }\end{array}$ \\
\hline 2. & $\begin{array}{l}\text { Workers from occupied North, West and Southeast Europe: } \\
\text { Norwegians, Danes, Dutch, Belgians, French, Czechs, Serbs, } \\
\text { Greeks }\end{array}$ \\
\hline 3. & $\begin{array}{l}\text { Workers from Baltic Countries \& Non-ethnic Polish citizens from } \\
\text { Generalgouvernement \& Białystok County: Estonians, Latvians, } \\
\text { Lithuanians, Polish-Ukrainians, Polish-Byelorussians }\end{array}$ \\
\hline 4. & Ethnic Poles \\
\hline 5. & $\begin{array}{l}\text { Workers from the Soviet Union (excluding Baltic countries, } \\
\text { Poles, Eastern Galicia); Italians (from 1943) }\end{array}$ \\
\hline 6. & Jews, Roma \& Sinti \\
\hline
\end{tabular}

The third level was made up of citizens from the Baltic countries, along with non-ethnic Polish citizens, mainly Ukrainians and Byelorussians from the Generalgouvernement and Białystok County, who had the same amount of work as other labourers, but received

\footnotetext{
${ }^{96}$ Spoerer, Zwangsarbeit unter dem Hakenkreuz, 91-2.
} 
lower wages. ${ }^{97}$ Poles and Soviet citizens, including 1.7 million Soviet Ukrainians, occupied the fourth and fifth levels respectively, and were some of the most stigmatized groups in Nazi society. ${ }^{98}$ Both groups were forced to wear badges identifying them as Poles or Ostarbeiter (literally 'Eastern worker,' but more accurately, 'Soviet worker'), and lived with lower wages and daily rations, as will be explored in the third chapter of this study. At the bottom of the list were Sinti, Roma, and Jews, who were typically worked to physical exhaustion and death. ${ }^{99}$ What is most significant for the purposes of this study, however, is the curious differentiation between Polish and Soviet Ukrainians, and how their placement on two different levels of the hierarchy influenced their day-today existence in the Reich.

There is a paucity of literature on why a distinction between Polish and Soviet Ukrainians was drawn. American historian Alexander Dallin is one of the only historians to touch upon why Polish Ukrainians, particularly those from Galicia, were raised to a level higher than most other Easterners. Dallin writes (albeit only in a footnote) that on one level Hitler claimed, "I know the Slav from my home country," attempting to validate the wisdom behind his periodical anti-Ukrainian and anti-Hungarian remarks, which were rooted in Hitler's experience with post-1918 political-ethnic pluralism in his native Austria. ${ }^{100}$ In a 1945 speech, he recalled that the "Austrian Ruthenians [Galician Ukrainians] were miserable, even in the Austrian Army," referring to their inferior

\footnotetext{
${ }^{97}$ The status of Polish-Ukrainians was decreased briefly during 1942, in some respects to the level of Poles and Jews.

${ }^{98}$ Białystok County is located in NE Poland, sharing a modern boundary with Belarus. It is the centre of the historical and multi-ethnic region of Podlachia, a melting pot of Byelorussian, Lithuanian, Polish and Ukrainian cultures.

${ }^{99}$ Spoerer, Zwangsarbeit unter dem Hakenkreuz, 91-92.

${ }^{100}$ Dallin, German Rule in Russia, 11.
} 
fighting abilities, deportment, and demeanour as soldiers. ${ }^{101}$ But as Dallin explains further, "at the same time, the very familiarity that bred contempt also induced him to keep the Galicians within close range and in a slightly more privileged status than the Soviet Ukrainians." ${ }^{102}$ While Third Reich archives are also relatively quiet on this favouring of Ukrainians from Galicia, one particular document sheds light on this important differentiation. In the minutes of a 19 May 1943 meeting on the situation in the Occupied Eastern Territories, involving the Reichsminister for Defence Hans Lammer, Reichsminister Rosenberg, occupied Ukraine's Reichskommissar Koch, and the Chancellor himself, Hitler made his opinions on the topic clear. "Russian Ukraine is not to be compared to Austrian Galicia," Hitler stated. "The Ukrainians living in Galicia have been under Austrian rule for a long time. These Austrian-Galician Ruthenians are closely integrated with the Austrian State." 103 Hitler's words did not bring about any major changes in the treatment of Ukrainians; they were already by the thousands in the Reich, and were treated differently depending on whether they came from Polish or Soviet Ukrainian territories. The words of Hitler are in keeping with the argument that the roots of the labour program can be traced back to the First World War. As mentioned earlier, the anthropologists who classified European prisoners of war in German camps distinguished between Slavs from within and outside the Austro-Hungarian Empire. Those who fell within the boundaries of the Soviet Union were later classified by the

\footnotetext{
${ }^{101}$ While the term Ruthenian is sometimes used as an ethnonym for Ukrainian people, the most typical usage in German sources is a generic term for Greek Catholic inhabitants of Galicia and adjoining territories who spoke Western dialects of the Ukrainian language, and called themselves Rsyny. Another English name for the same ethnic group was "Little Russians." I use the term "Galician Ukrainians" to describe this group.

${ }^{102}$ See footnotes of Dallin, German Rule in Russia, 11.

${ }^{103}$ Minutes of meeting between Hitler, Rosenberg, Koch, Lammers and Himmler, 19 May 1943, BArch R 58/1005, fol.10-14.
} 
Nazi regime as Untermensch, while those from the former lands of the Dual Monarchy, Polish Ukrainians included, were viewed as familiar and familial.

Hitler's comments emphasised the peculiar, rather flexible nature of the Nazi concept of race, which also took into account a nation's political and cultural background. In stressing a common history as part of the Austro-Hungarian Empire, Nazi officials granted Polish Ukrainians preferential treatment over their Soviet fellow nationals, as will be explored in depth in the third chapter. Not only did Hitler's words in May 1943 justify the general differential treatment afforded to civilian workers, but they also gave justification to the establishment of a distinctly Ukrainian SS army unit created three weeks earlier, clarifying further, "It is therefore possible in Galicia to establish a Ukrainian Division through the SS." ${ }^{104}$ The stage was therefore set for Ukrainians to have quite different experiences in Germany, depending on their citizenship at the outbreak of war with Poland. While plans rooted in the German Great War experience to assimilate and starve the native populations of the East were not carried out, and the establishment of ethnic German colonies took place only on a limited basis, the Nazi ideology behind these plans, including racial-political considerations, certainly informed decisions on how Ukrainian and other foreign labourers were treated, and as chapter three explains, certainly had an impact on the day-to-day lives of labourers.

This chapter has provided a comprehensive overview of the background of foreign labourers in Germany and the ideological underpinnings of the labour program. Labour shortages during the Second World War were nothing new to Germany. Nor was

\footnotetext{
${ }^{104}$ Minutes of meeting between Hitler, Rosenberg, Koch, Lammers and Himmler, 19 May 1943, BArch R 58/1005, fol.10-14.
} 
the use of Eastern European labourers without precedent. It was during these initial experiences with foreigners that the tradition of legal and social discrimination took root, reappearing with the employment of ethnic Polish citizens from 1939, and from 1941 labourers from the Soviet Union. Underlying the treatment and philosophy towards the millions of Ukrainians and other Eastern Europeans who came to the Reich was hostile Nazi ideology, which was similarly rooted in the German First World War experience East of the River Oder. Nazi ideology towards the "Jewish-Bolshevik" Soviet Union and other enemies of Germany and the former Austria-Hungary, developed by anthropologists working in prisoner of war camps, was especially virulent, echoing European colonialism from the end of the previous century. Even before the decision was made for Polish and Soviet Ukrainians to enter the Reich as farm and factory labourers, they had been targeted by Hitler, in Mein Kampf, and Nazi ideologues for assimilation, subjugation and elimination. ${ }^{105}$ Such plans, however, were not fully carried out. War exigencies, as described in the next chapter, made ethnic Ukrainians more valuable alive than dead. Nazi wartime production officials saw the pragmatism in bringing them to the Reich en masse as labourers, rather than Germanic-looking individuals for assimilation. While ideological restrictions were relaxed with the deployment of two million ethnic Ukrainians to the German heartland, they were not fully forgotten. The Nazi ideology that drove plans to colonise the vast steppes of the East still certainly informed decisions on how Ukrainian and other foreign labourers were treated, and as chapter three explains, certainly had an impact on the day-to-day lives of labourers. The division of Polish and Soviet Ukrainians, furthermore, along lines of citizenship proves to be an interesting

\footnotetext{
${ }^{105}$ For more on Nazi plans to racially screen the native population, see Brown, Biography of No Place, $192-225$.
} 
example of the political-historical aspect of the racial Nazi hierarchy, which would have (sometimes grave, but also sometimes ambiguous and contradictory) consequences on the treatment of Soviet Ukrainians over their favoured Polish Ukrainian fellow nationals. 


\section{Chapter 2 - The Twisted Route to Labour Deployment}

Before the regulations dictating the lives of Ukrainian labourers can be discussed and examined, and a thorough picture of their daily life in the Reich attained, the context and major events surrounding the labour deployment must be explored. This chapter, using a chronological approach breaking the events into three distinct temporal phases, aims to do just that. In tracking the major events that brought hundreds of thousands of ethnic Ukrainians to the Reich, one can note how their deployment closely followed the war fortunes, and how Nazi ideology was relaxed or put aside for political and pragmatic reasons. This calls into question the sincerity of Nazi officials in carrying out party ideology as it pertained to race, and therefore permits the argument that National Socialists applied racial-political ideology more liberally to Ukrainian and other foreign labourers as German war fortunes deteriorated and production demands increased. Nazi racial policies remained in tact throughout the course of the war, but their tone and their application to deployed ethnic Ukrainians gradually softened.

The first phase of Ukrainian labour deployment was roughly from September 1939 to February 1942, during which time the vast majority of Ukrainians in the Reich held Polish citizenship. These Polish Ukrainians, from the former Austro-Hungarian province of Galicia were favoured over ethnic Poles, and had comparatively humane living and working conditions. This phase also saw the foundation of the Ukrainian National Alliance in November 1939, the precursor to the Ukrainischer Hauptausschuss (UHA, Ukrainian Central Committee, Ukraïns'kyi Tsentral'nyi Komitet) which acted as the representative body of Polish Ukrainians in Occupied Poland as well as in the German Reich. The second phase was roughly from June 1941, when Soviet Ukrainians 
began to enter the Reich following the invasion of the Soviet Union. Harsh regulations dictated life in the Reich for Soviet citizens, in the form of the Ostarbeitererlasse (Eastern Worker Decree), from February 1942 until February 1943, when the Red Army defeated the Wehrmacht at Stalingrad. During this period, thousands of Soviet Ukrainian labourers entered Germany, and were subject to blatantly racist and inhumane treatment. Concurrently, the status of Polish Ukrainians was temporarily reduced to the level of Poles, in regards to labour rights and taxation. ${ }^{106}$ The final period lasted from February 1943 until the end of the war in May 1945, during which the regulations concerning Ukrainians from both jurisdictions were substantially liberalised, at least on paper, to the level of Western workers. However, rather than a marked increase in living and working standards, life for most Ukrainians, particularly those in urban areas, was characterised by ever-persistent allied bombing raids, which caused working and living conditions to consistently deteriorate.

\section{I: The Polish Campaign \& the First Ukrainian Labourers}

On 1 September 1939 the Second World War began with the Nazi invasion of Poland. It also marked the beginning of the deployment of over 700,000 Polish Ukrainians, and later 1.7 million Soviet Ukrainians, to the farms and factories of the Reich. The conclusion of the Polish campaign resulted in the ceding of Eastern Galicia, centred in L'viv (Lwów, Lemberg) to the Soviet Union, as agreed to in a secret clause of the Molotov-Ribbentrop Pact. While the campaign resulted in the largest unification of Ukrainian peoples under a single state, 744,000 Ukrainians in Cholmland, Podlachia, and

\footnotetext{
${ }^{106}$ Spoerer, Zwangsarbeit unter dem Hakenkreuz, 156-7.
} 
Western Galicia remained in the Generalgouvernement, the newly formed administrative unit for occupied Poland. ${ }^{107}$ These would be the first Ukrainians to experience labour in Nazi Germany, joined by Polish-Ukrainian prisoners-of-war, and ethnic Ukrainian refugees fleeing the Soviet-occupation of East Galicia.

The registration and conscription of civilians for labour in the Reich began immediately after the first troops entered Poland. Irena Sroka writes,

In the economically important region of East Upper Silesia, which Germany had to relinquish in 1920 to Poland, the Labour Deployment officials directly followed the German troops, and already began on the first day of September to register the entire population between 14 and 60 , sometimes to 70 years old. Those who did not report to the Labour Office at the specified time were punished with a high fine. ${ }^{108}$

On 3 September the first German labour office opened in the Upper Silesian town of Rybnik, and within one month, a total of 115 labour offices had been opened throughout the former Republic, processing ethnic Poles, Ukrainians and Byelorussians for labour in the Reich. ${ }^{109}$ The first shipment of civilian labourers departed 19 September from Gdynia (Gdingen) and Gniezno (Gnesen), and by the end of the first month of conflict, 10,000 were deployed; by years end, the total was close to $40,000 .^{110}$

The first movements of labourers involving ethnic Ukrainians were not civilian, but rather prisoner-of-war transports, which were sent within a matter of days of the invasion. Polish-Ukrainian prisoners-of-war from the Republican Armed Forces were sent to East Prussian estates to harvest root crops, after having been processed in transit

\footnotetext{
${ }^{107}$ Meldungen aus dem Reich \#146, Reich Security Police, 12 January 1940, BArch R 58/147, fol.38. ${ }^{108}$ Spoerer, Zwangsarbeit unter dem Hakenkreuz, 46.

${ }^{109}$ Rachner, "Arbeitseinsatz und Arbeitseinsatzverwaltung in den besetzten Gebieten," Reichsarbeitsblatt 19/2 (1939):372.

${ }^{110}$ Herbert, Hitler's Foreign Workers, 62; Spoerer, Zwangsarbeit unter dem Hakenkreuz, 46.
} 
camps and screened by doctors and police. ${ }^{111}$ By the end of September 100,000 prisoners-of-war had been deployed and by year's end, a total of 300,000 were working in German agriculture. By the end of the war, nearly 420,000 Polish prisoners-of-war had been captured and re-deployed to the Reich. Of this total, 85,000 or $20 \%$ were ethnic Ukrainians. ${ }^{112}$ But whereas ethnic Polish prisoners-of-war were kept under armed guard, and deployed in groups, Ukrainians were reclassified as civilians upon entry into Germany, and deployed individually or in pairs to smaller, private farms. ${ }^{113}$ This differential treatment can be attributed to the desire to splinter and divide the populations of the East, as previously discussed as part of Nazi plans for Eastern Europe. Specifically, the Germans hoped to channel Ukrainian discontent over years of Polish suppression and Polonisation into active support for the German occupation authorities, who distinguished between the two ethnicities. ${ }^{114}$ However, faced with labour shortages in industry, and Geneva Convention stipulations that stated prisoners-of-war were not to be employed in the manufacture of armaments and munitions, it was announced in February 1940 that all remaining Polish POWs (excluding Polish-Jews) were to be reclassified as civilians, thereby making their deployment more flexible and freeing up German surveillance personnel. $^{115}$

This phase of Ukrainian labourer deployment also saw the foundation of the Ukrainian National Alliance (Ukraïns'ke Natsional'ne Ob'iednannia), which was created

\footnotetext{
${ }^{111}$ Rachner, "Arbeitseinsatz und Arbeitseinsatzverwaltung," 37.

${ }^{112}$ Miroslav Yurkevich, "Galician Ukrainians in German Military Formations and in the German Administration," in Ukraine during world war II. History and its aftermath. A symposium, ed. Yury Boshyk and Roman Waschuk (Edmonton: Canadian Institute of Ukrainian Studies, 1986), 74.

${ }_{113}$ Spoerer, Zwangsarbeit unter dem Hakenkreuz, 45.

${ }^{114}$ For more on Nazi occupation policies in Occupied Poland, see Chodakiewicz, Between Nazis and Soviets.

${ }^{115}$ Spoerer, Zwangsarbeit unter dem Hakenkreuz, 45.
} 
in November 1939 under the leadership of Volodymyr Kubijovyč. ${ }^{116}$ The Ukrainian National Alliance served as the representative body for ethnic Ukrainians in the Generalgouvernement, and had a semi-legal existence until June 1940, when the occupation authorities finally approved Polish, Jewish and Ukrainian representative structures in Occupied Poland. It was at this time that the name was changed to the Ukrainischer Hauptausschuss (UHA, Ukrainian Central Committee, Ukrä̈s'kyi Tsentral'nyi Komitet). Established as a social-welfare agency, the Hauptauschuss had two objectives: firstly it organised and conducted general social work in the Generalgouvernement, including the (re-) establishment of Ukrainian-language schools, provision of care to the sick, aged and homeless children and assistance to PolishUkrainian prisoners of war; and secondly, cooperated with foreign relief organisations via the German Red Cross in the provision of relief supplies. ${ }^{117}$ Over time, the Ukrainischer Hauptauschuss's work expanded in scale and scope. It dealt with ecclesiastical problems involving Ukrainian Greek Catholic and Ukrainian Orthodox Churches and was commissioned by the German administration authorities to issue identification cards. It also satisfied its own hidden agenda, which consisted of countering strong Polonising influences on its isolated Ukrainian constituents and raising their national consciousness. ${ }^{118}$ As more and more Ukrainians were deployed to Germany, the Ukrainischer Hauptauschuss also took it upon itself to speak and act for those in the Reich, politely condemning the maltreatment of Polish Ukrainians, for example, and providing extra food at Christmas for those deployed to factories. Although the Ukrainischer Hauptauschuss cooperated with the Nazi occupation authorities in the

\footnotetext{
${ }^{116}$ Introduction to collection, Ukrainian Central Committee, 25.

${ }^{117}$ Ibid; Subtelny, Ukraine: A History, 457.

${ }^{118}$ Subtelny, Ukraine: A History, 457.
} 
fulfilling of its work, it is not commonly viewed as a collaborating organisation. ${ }^{119}$ It was also strictly forbidden by Generalgouvernement Governor General Hans Frank to take on any political prerogatives. ${ }^{120}$ The UHA did its best to satisfy German war requirements on one hand, while, on the other, protecting the Ukrainian population for excessive demands for food deliveries, labour for German farms and factories, and the enrolment of young men in the Construction Service. In caring for ethnic Ukrainians deployed to the Reich, the Hauptauschuss worked closely with the Berlin-based Ukrainische Vertrauenstelle (Ukrainian Trust Authority), which was founded in 1938 under the leadership of Nikolaus Suszko, and initially busied itself with helping stateless Ukrainians throughout the Reich in dealings with the bureaucracy. ${ }^{121}$

\section{I: The Polererlasse of 8 March 1940 and the Treatment of Polish Ukrainians}

Even with the reclassification of prisoners-of-war, it soon became clear that their use alone would not satiate the growing demand for labour. ${ }^{122}$ Already in November 1939, Reich Agricultural Minister Walter Darré set a target of two million Poles to be at the disposal of the Reich in $1940 .{ }^{123}$ A much more extensive deployment was required, and would prove to be a formidable task.

The first step to a mass mobilisation of Polish citizens was a mandatory work duty, announced in October 1939 by Governor General Hans Frank as his first official act of business. Many Poles in the newly formed Generalgouvernement were therefore

\footnotetext{
${ }^{119}$ Introduction to collection, Ukrainian Central Committee, 27.

${ }^{120}$ Subtelny, Ukraine: A History, 457.

${ }^{121}$ The precise role of the Ukrainian, as well as Russian and Byelorussian, Vertrauenstelle (Trust Authority) in caring for thousands of their fellow nationals in the Reich deserves further research.

${ }^{122}$ Herbert, Hitler's Foreign Workers, 63.

${ }^{123}$ Ibid.
} 
compelled by occupation officials to work in the Reich. Unemployment benefits in the economically depressed Polish territories were only distributed through registration with the German occupation authorities, making the Arbeitspflicht (work duty) for unemployed residents relatively easily imposed. ${ }^{124}$ The second step was a codification of the treatment of Polish workers. The 8 March 1940 two-page document "Conditions of ethnic Polish civilian labourers during their residence in the Reich," and nine additional documents that elaborated on the original, are described by Herbert as a "milestone" in the history of Nazi foreign worker policy. "It was the first step toward an increasingly more consolidated special code for foreign workers in Germany, differentiated by nationality, and formed the basis of a comprehensive system of surveillance and repression of Polish workers." ${ }^{125}$ The regulations, which were largely in force until the end of the war, symbolised a compromise between the manpower needs of German industry and agriculture and National Socialist racial doctrine, which needed proof of its superiority over ethnic Poles.

The regulations spelled out a strictly controlled existence in Germany. Leaving the town or city of employment was forbidden, as was the use of public transportation without special permission from the local police. Social interaction with Germans was largely prohibited, with a ban on Poles entering German theatres, cinemas, dance halls, churches, bars and restaurants. For the first time in the history of the Third Reich, citizens would be marked; on the right breast of each piece of clothing, ethnic Poles were to wear a $5 \times 5 \mathrm{~cm}$ badge, featuring a purple ' $\mathrm{P}$ ' on a yellow background, a regulation that would be

\footnotetext{
12430 September 1939 Czeslaw Luczak, ed., Polozenie polskich robotników przymusowych w Rzesy, 19391945, Documenta Occupationis, vol. IX (Poznan: Instytut Zachodni, 1975), Doc. IV.I, herein known as Doc. Occ; Spoerer, Zwangsarbeit unter dem Hakenkreuz, 47.

${ }^{125}$ Herbert, Hitler's Foreign Workers, 71.
} 
modified and extended to Jews in September 1941. And misdemeanours were to be harshly penalised; for example, misconduct in the workplace was to be punished with forced labour in concentration camps, while sexual intercourse with Germans would lead to the imposition of the death penalty. ${ }^{126}$

While the regulations spelled out within the documents did not apply to PolishUkrainians, they would serve as the model for regulations released two years later concerning the treatment of Soviet Ukrainians. Furthermore, due to bureaucratic confusion and a lack of familiarity with the stateless ethnic Ukrainians of Poland, many were classified as ethnic Poles when processed on their way to the Reich, and were subject to the harsh living conditions of one of Nazi Germany's most hated peoples. ${ }^{127}$ The misidentification of both Polish Ukrainians and Byelorussians as ethnic Poles continued repeatedly throughout the course of the war, often causing "noticeable unrest and discontent" amongst the 200,000-strong workforce. ${ }^{128}$ When one 18-year-old labourer first entered the Reich in 1942 from eastern Galicia, he was forced to wear a 'P' badge, denoting him as a Polish worker. "I had to wear a tag, either a 'P' for Polish or 'OST' for Russia,” he explained. “I didn't want either...Pollack or Russian...Gestapo says I have to wear one and could only go within $3 \mathrm{~km} .{ }^{.129}$ However, the particular labourer's status as a Pole was not static, and through communication with the Ukrainische Vertrauenstelle (Ukrainian Trust Authority) in Berlin, an arm of the Krakow-based Ukrainischer Hauptausschuss, he was able to be reclassified as a Polish-

\footnotetext{
${ }^{126}$ Decree, Reichsfithrer of the SS and Chief of the German Police to State Police offices, 8 March 1940, BArch R 58/1030, fol.32.

${ }^{127}$ Ukrainischer Hauptauschuss leader Kubijovyč to Department of Labour, Government of the Generalgouvernement, 6 February 1941, Ukrainian Central Committee, p.191-2.

${ }^{128}$ Reich Ministry of Labour to Labour Offices, July 1941, BArch R 3901/20480.

${ }^{129}$ Makuch, "My Life," 3.
} 
Ukrainian. "I30 "I wrote a letter with a picture and birth certificate for Ukrainian ID. I talked back to the Gestapo and told them I'm Ukrainian," he wrote. Due to his residency in Galician Ukraine, the labourer was rewarded. He did not have to wear an identification badge of any sort, and, "they gave me better curfew."131

Unlike the Poles, there existed no comprehensive set of regulations published to deal with non-Poles from the Generalgouvernement. An idea of how Polish-Ukrainians were treated can therefore best be extracted from reports and documents of the Ukrainischer Hauptausschuss, which spoke on behalf of Polish Ukrainians, both in the Generalgouvernement and in the Reich. Starting in 1942, the status of Polish Ukrainians worsened, which Ukrainian labourers greeted with anger and protest, and expressed in letters of complaint to the Hauptausschuss. ${ }^{132}$ The rationale and the particulars of just how the status of Polish-Ukrainians changed will be discussed later. What is important here are the particulars of their status before it declined. In communication with the Generalgouvernement on the treatment of his fellow nationals in the Reich, leader of the Ukrainischer Hauptausschuss Volodymyr Kubijovyč wrote, "until the end of 1941, the Ukrainians in Germany were always equal with Germans as well as foreign workers from German-friendly countries, in terms of social-, work- and tax law."133 Polish Ukrainians and Byelorussians alike were therefore exempt from such stigmatizing regulations as the badge obligation, and presumably permitted to frequent taverns, theatres, cinemas and churches with Germans and other foreigners. In another memo to the occupation

\footnotetext{
${ }^{130} 14$ January 1939, BArch NS 43/42, p.319.

131 Makuch, "My Life," 3.

${ }^{132}$ Kubijovyč , Note for the Records and letter from Polish Ukrainians in Iron Works camp in Trofaiach, Ostmark, 15 May 1942, Ukrainian Central Committee, p.414-7.

133 "Behandlung der Ukrainer aus dem Generalgouvernment im Deutschen Reiche," June 1942, Ukrainian Central Committee, p.392.
} 
administration, Kubijovyč wrote simply, "Ukrainians from the Generalgouvernement feel like West Europeans... and hope to be treated appropriately." ${ }^{134}$ Rather than existing as a national group to be assimilated and eliminated as per Nazi policy at the onset of the 1939 attack on Poland, Polish Ukrainians saw themselves as equal to other Europeans. And although their status within the political-racial hierarchy was not as high as Western Europeans, their superior position vis-à-vis ethnic Poles and Soviet Ukrainians shows the flexibility of Nazi ideology, justifying Kubijovyč's pleas to improve Polish-Ukrainian status. The inferiority of ethnic Poles to Polish Ukrainians also reflects the Nazi course of war. Feeling triumphant over their rapid victory over the Polish Republic, National Socialists continued the harsh treatment of ethnic Poles. They kept the status of Polish Ukrainians high not only for historical reasons, but to compound the feeling of defeat on the Polish nation, which had oppressed and Polonised the minority Ukrainians for decades.

\section{I: Forced Recruitment in the Generalgouvernement}

The third step to a mass mobilisation of Polish citizens was an extensive recruitment campaign. Initially, the labour office officials relied on voluntary recruitment, as was the case before the war. After demand for labourers from the Generalgouvernement reached one million workers, recruitment quotas were established for districts, which were filled by village leaders. ${ }^{135}$ But within six months of the invasion of Poland, the numbers of volunteers dried up. By March 1940, Polish citizens were growing angry and increasingly opposed to deployment, as news of the actual working

\footnotetext{
134 "Behandlung der Ukrainer aus dem Generalgouvernement im Reich," June 1942, Ukrainian Central Committee, p.394.

${ }^{135}$ Order, Chief of Krakow District, 25 January 1940, Doc. Occ. X, Doc. IV.8.
} 
and living conditions, discussed in the next chapter, filtered back. For the first four months of 1940 a quota of 500,000 had been established, but only 210,000 had been successfully deployed. ${ }^{136}$ To further meet quotas, on 24 April Frank issued a massive conscription call: all non-German inhabitants of the Generalgouvernement born between 1915 and 1925 (15-25 year olds) were ordered to the Reich. Furthermore, in a significant break with previous practice, Frank authorised the use of coercion if necessary, with the caveat that "excesses" should be avoided. ${ }^{137}$ Fear increasingly spread across the former Polish Republic at the prospect of 'recruitment,' leading inhabitants to hide in forests, for example, as deployment dates drew nearer. To instil anxiety and fear, and emphasise the futility of avoiding conscription, the SS and Polish police carried out "exemplary" measures in every district. In the countryside, this meant the sudden encirclement of villages to ensure quotas were met. In towns, the police resorted to snatching nonregistered workers off the streets. ${ }^{138}$ Despite the attempt at mass mobilisation, and the use of such coercive measures, success was limited. Between January 1 and June 30, 1940, 272,238 Polish citizens had been recruited for work in Germany, bringing the total to 311,913 since the beginning of the war, still lower than the number of forced conscripts during the First World War. ${ }^{139}$ In May 1940, international attention to the deployment of Poles to the Reich, as well as pressure from Berlin to meet recruitment quotas, eased with the commencement of the Battle of France. By the end of May, a total of 1.2 million prisoners-of-war and foreign civilians were in Germany. Over $60 \%$ were working in agriculture, almost exclusively the 700,000 citizens from Poland. With a ratio in

\footnotetext{
${ }^{136}$ Herbert, Hitler's Foreign Workers, 82.

${ }^{137}$ Communication, Government of the Generalgouvernement to Heads of Labour Offices, 15 June 1940, Doc. Occ. X, Doc. IV.17.

${ }^{138}$ Statement by Timm at Nuremberg Trials, 31 May 1946, IMT, vol.15, p.233.

${ }^{139}$ Herbert, Hitler's Foreign Workers, 84.
} 
agriculture of 64 foreigners per 1,000 Germans, and in industry of 24 foreigners per 1,000 Germans, it was evident, "that the Germans could not continue the war without foreign labour, nor would they be able to manage without it afterward."140 As the scope of the war expanded from Western Europe to the Russian steppes, the need for labour only increased.

\section{II: Operation Barbarossa and the First Soviet Ukrainians}

In February 1943 the Red Army was defeated by the Wehrmacht at Stalingrad, marking the end of a period that began roughly in June 1941 with the German invasion of the Soviet Union and the capturing of thousands of Soviet Ukrainian Red Army soldiers, who were later released based on their Ukrainian ethnicity. Not only did this phase in the labour program bring thousands of former Soviet prisoners-of-war to the Reich, it saw an unprecedented increase in the number of civilian labourers, the vast majority from Soviet Ukraine. These labourers found themselves subject to blatantly racist and inhumane treatment, outlined in the February 1942 Ostarbeitererlasse. It was also during this phase that the distinction between Polish and Soviet Ukrainians was most visible, with Soviet Ukrainians leading a prisoner existence in the Reich, while Polish Ukrainians had almost the same freedoms as Western Europeans. This lasted until February 1943, when the Red Army defeated the Wehrmacht at Stalingrad, and German officials, recognizing the importance of Ukrainian labourers to the war effort and the changing war fortunes, largely relaxed the heavy-handed regulations guiding their residence in the Reich.

\footnotetext{
${ }^{140}$ Herbert, Hitler's Foreign Workers, 84.
} 
Less than two years after the invasion of Poland, German forces invaded the Soviet Union as part of Operation Barbarossa, an attempt to realise Nazi goals of a racially-pure Lebensraum in the East. Original planning for the June 1941 campaign assumed that the Wehrmacht would be met by a weak Red Army, inherently 'subhuman,' and depleted of strategic military planning ability due to Stalin's officer purges of the 1930s. According to military planners, Germany's Blitzkrieg victories in Poland, France and across Western Europe would be easily repeated in the East and Wehrmacht soldiers would be heading home to celebrate Christmas in Germany by December. Although the long-term goal was to use the newly acquired vast swaths of land for colonisation, the regime's immediate war booty would be grain, to help alleviate food shortages at the centre of the Reich. The Soviet population would essentially be starved en masse. ${ }^{141}$ Unlike the Polish Campaign, plans for Operation Barbarossa did not foresee the largescale use of Soviet civilian or prisoner-of-war labour in the Reich. A quick victory would negate any need to ship any number of 'subhumans' to work in the Reich. To this point, the use of Russian prisoners-of-war was strictly prohibited, except on the front lines. ${ }^{142}$ However, as persistent labour shortages on the home front combined with a prolonged war in the Soviet Union, the Labour Ministry and Reich Main Security Office (Reichssicherheitshauptamt) drew up plans to deploy Russian civilian workers, which were declined by Göring for about two months. ${ }^{143}$ In the meantime, Hitler gave the green light for a conditional deployment of Soviet prisoners-of-war as labourers in Germany on

\footnotetext{
${ }^{141}$ Memo, 2 May 1941, IMT Doc. 2718PS, vol.31, p.84.

${ }^{142}$ Christian Streit, Keine Kameraden. Die Wehrmacht und die sowjetischen Kriegsgefangenen 1941-1945 (Stuttgart: Deutsche Verlags-Anstalt, 1978), 193.

${ }^{143}$ Herbert, Hitler's Foreign Workers, 151-2.
} 
15 October 1941, followed by a comprehensive deployment 16 days later. ${ }^{144}$ SA Minister Hermann Göring reasoned that the employment of foreign nationals would keep women away from factories, thereby placating the complaints of some Nazi ideologues and justifying the decision to bring thousands of 'racial enemies' to the centre of the Reich. ${ }^{145}$ By the time Nazi military officials and big business leaders realised the potential of Soviet prisoners-of-war, though, thousands of Soviet Byelorussians, Russians and Ukrainians had already perished in POW camps. Despite later efforts to rehabilitate prisoners-of-war, who for months lived outdoors on starvation rations, the number of Soviets deployed by the end of March 1942 was dismal, and the number who died was extreme. Of a total of 3,350,000 Soviet prisoners taken from June 1941 to the end of March 1942 , only 166,881 , or $5 \%$, were actually deployed as workers officially classified as "prisoner-of-war." Out of the rest, $25 \%$ died and the others were deemed racially or physically unfit. ${ }^{146}$ By the end of the war, two million or $45-55 \%$ of the 5.1 million captured Soviet prisoners-of-war perished. ${ }^{147}$ It is not clear precisely how many ethnic Ukrainians perished in prisoner-of-war camps, or later entered the Reich classified as Soviet prisoners-of-war, as an ethnic breakdown of Soviet POWs is not available. However, this author believes that the number is not high. In November 1941, five months after the commencement of aggression against the Soviet Union, Reichsmarschall Göring issued a decree calling for the release of all ethnic Byelorussian and Ukrainian

\footnotetext{
${ }^{144}$ Memo by Göring on how many POWs were to be deployed, 11 November 1941, IMT 1206PS p.64, vol. XXVII; Herbert 145-6

${ }^{145}$ Herbert, Hitler's Foreign Workers, 149.

${ }^{146}$ Commissioner for the Four-Year-Plan Business Group Labour Deployment to Reichsmarschall of the Great German Reich, 10 February 1942, BArch R 3901/20281, fol.270.

${ }^{147}$ Theo J. Schulte, The German Army and Nazi Policies in Occupied Russia (Oxford: Berg Publishers, 1989), 181.
} 
Red Army prisoners-of-war. ${ }^{148}$ Although the decree was curiously revoked for Ukrainians five months later, it had already made an impact. Malnourished and ill-treated Soviet Ukrainian POWs had already been released to return to their hometown or closest relatives, and in cases where this was not possible, were some of the first volunteers to work in Germany. The mass starvation of Soviet prisoners of war at the hands of the Wehrmacht, while motivated by Nazi ideology and war aims, also reflected the Nazi confidence in their Eastern campaign. The Wehrmacht saw no use for the thousands of prisoners of war, foreseeing an easy victory in Russia, and a quick reordering of Europe.

The first few months of German rule in Soviet Ukraine also saw little movement of civilian workers to the Reich, as it was assumed an endless supply of prisoners-of-war would be able to satiate labour demands. There also existed a fear in the Wehrmacht that recruiting civilians would lead to wide scale growth of the partisan movement, and furthermore, that a sufficient bureaucracy to racially and politically screen Soviet citizens could not be established. ${ }^{149}$ The approval to use Soviet civilians was issued 7 November, and was initially restricted to mine-workers, who "would work in large, self-contained work gangs, be housed in special camps, be kept segregated from the other workers and given pocket money instead of regular wages," much like POWs. ${ }^{150}$ The first reported transfer of Soviet Ukrainians to Germany took place one month later, when two groups of workers boarded westward-bound trains from the industrial centres of eastern Ukraine. Seven hundred and sixty miners departed from Kryvy Rih, and 6,400 unemployed metal

\footnotetext{
${ }^{148}$ Commissioner for the Four-Year-Plan to the Reich Minister for the Occupied East, 4 April 1942, BArch R 3901/20170, fol.135.

${ }^{149}$ Herbert, Hitler's Foreign Workers, 152.

${ }^{150} 7$ March 1941, IMT 1193-PS, vol. XXVII, p.56.
} 
workers left from Zaporizhzhia to work in the factories and plants of the Ruhr Valley. ${ }^{151}$ Although the number was relatively small, the initial use of miners and metal workers set a precedent for the future use of Soviet Ukrainian civilians. These initial workers also experienced some of the harshest treatment amongst foreign labourers, a result of German confidence in their goals in the Soviet Union, and virulent racist ideology being spread on the home front, manifested physically in the previously discussed brochure Der Untermensch.

\section{II: 20 February 1942: "The General Conditions"}

The February 1942 death of Fritz Todt, Reich Minister for Armaments and Munitions (and the Leader of Organisation Todt, a paramilitary civil and military engineering corps,) became an opportunity for a Nazi personnel and organizational shuffle. Organisation Todt combined with the Ministry for Armaments and Munitions, oversaw government and industry employment of the vast majority of non-agricultural foreign labourers. The most significant appointment for Ukrainian workers was that of the party loyalist Fritz Sauckel to the newly formed position "Plenipotentiary General for Labour Deployment" (Generalbevollmächtiger für Arbeitseinsatz). Sauckel was appointed to guarantee the importation of hundreds of thousands of Soviet labourers, and arrange their maximum exploitation, political repression and racial classification through an "appropriate" form of treatment. ${ }^{152}$ The ramifications of Sauckel's decisions and directives would impact directly on the lives of all Ukrainians deployed in the Reich.

Before Sauckel assumed his position in March 1942, one of the most influential and comprehensive set of regulations to date concerning the recruitment and deployment

\footnotetext{
${ }^{151}$ Berkhoff, Harvest of Despair, 253.

${ }^{152}$ Responsibilities of the new Plenipotentiary General for Labour Deployment, 21 March 1942 and 27 March 1942, IMT 1666-PS vol. XXVII, p.432
} 
of civilian East Europeans was released on 20 February by Reinhard Heydrich's Reich Main Security Office. ${ }^{153}$ The regulations, which superseded Sauckel's 7 May 1942 "Fourth Decree" concerning both Eastern and Western labourers, dealt with recruitment, medical examinations, racial-political screening procedures, accommodation, free time activities, surveillance, and the use of identifying badges for Eastern Europeans. ${ }^{154}$ Regarding Polish Ukrainians, the regulations resulted in a degradation of their status, from almost en par with Western and Northern European workers to essentially the same level as Baltic citizens, just above the status of ethnic Poles. The populations of East Europe were roughly broken up into four civilian groups: citizens from the former Soviet Union, who were referred to as Ostarbeiter (excluding the former Lithuania, Latvia and Estonia, Białystok County and the District of L'viv); citizens from the Baltic States, who were also sometimes referred to as Ostarbeiter (Lithuania, Latvia and Estonia); ethnic Polish citizens from the Generalgouvernement and other parts of the Polish Republic, and lastly non-ethnic Polish civilians from the same geographic areas; including PolishUkrainians, -Byelorussians, -Russians, and such minority groups from Prussia as the Kashubians and Mazurians. In dealing with ethnic Poles, the regulations simply referred to the Polererlasse of 8 March 1940 and subsequent appendices, and therefore did not bring about any changes of significance. The regulations dealing with Soviet Ukrainians and other Soviet citizens were based on previous experiences with ethnic Poles, and modelled after the largely efficient Polererlasse. The regulations of February 1942 were amended for the first time two months later, and resulted in a slightly less severe

\footnotetext{
${ }^{153}$ Decree, Reichsführer of the SS and Chief of the German Police, 20 February 1942, BArch R 3901/20481, fol.58-70

${ }^{154}$ Decree \#4, Plenipotentiary General for Labour Deployment, 7 May 1942, BArch R 3901/20471, fol.516
} 
treatment of Soviet labourers. The changes did not come about in any way from a change in racial policy, but rather from slumping recruitment numbers in the newly formed Reichskommissariat Ukraine, where word was flowing back of the inhumane treatment Ukrainians were receiving in the Reich. ${ }^{155}$

In general terms, the regulations of February 1942 called for a strict differentiation between Soviet and Polish Ukrainians. In handling the Soviet Ukrainians, the preamble of section A concerning workers from the "Old Soviet Realm," reminded government officials that, "these workers have lived for decades under Bolshevik command, and have been systematically trained to be enemies of National Socialist Germany and European culture." ${ }^{\text {156 }}$ The regulations spelled out for Soviet Ukrainians and other Soviet citizens were consequently severe and punishing, at least in the initial stages of deployment. They were forced, for example, to wear an identifying badge (modelled after the 'P' badge of March 1940), to live in barbed-wire surrounded barracks, and had no freedom to leave their camps. The handling of Polish Ukrainians, conversely, was more of a balancing act. On one hand, Polish Ukrainians and other non-ethnic Polish citizens of the Generalgouvernement were "to be positioned...opposing ethnic Poles and placed more liberally than them in the German Reich." On the other hand, "living standards, character and political instructions of these workers cannot be brought in unison with the German living standard." ${ }^{157}$ This differentiation between the two "types' of Ukrainians is in keeping with the previously described Nazi racial-political hierarchy, in which Soviet Ukrainians were classified with other Soviet citizens as one of the most

\footnotetext{
${ }^{155}$ Decree, Reichsfïhrer SS and Chief of the German Police, 9 April 1942, BArch NS 3/512, fol.282-3.

${ }^{156}$ Decree, Reichsführer of the SS and Chief of the German Police, 20 February 1942, BArch R 3901/20481, fol.58-70.

${ }^{157}$ Ibid.
} 
stigmatised groups in status, only one step higher than the Jews, Roma and Sinti, and Polish Ukrainians were ranked higher than Poles, but not as privileged as Dutch, French and Swedish labourers. ${ }^{158}$ One significant change for Polish-Ukrainians during this phase of Ukrainian deployment, which was met with an outcry from the Ukrainischer Hauptausschuss, was a change in their labour-law status, from being nearly on the same level as ethnic Germans, to the same level as ethnic Poles. This change, in effect from February 1942 but reversed by early 1943, was made for seemingly unknown reasons, but could have simply coincided with a sharpened anti-Eastern European sentiment with the ongoing attack on the Soviet Union. ${ }^{159}$ The division of Ukrainians in general serves as an interesting example where political history was more important than race alone. This is in keeping with Nazi policy in general, as an evolving set of imperatives linked to the changing course of Germany's war.

The February 1942 "General Conditions" were further expanded upon by secret detailed regulations from the Reich Main Security Office in July 1942, at which time the Plenipotentiary General for Labour Deployment also published a series of leaflets regarding the massive deployment of Ostarbeiter, one for plant managers and one for the Ostarbeiter themselves. ${ }^{160}$ The leaflets became a concise reference of the various decrees and regulations guiding the deployment of Soviet workers, to complement Sauckel's "Fourth Decree" of May 1942 that in principle covered all foreign workers, but in reality,

\footnotetext{
${ }^{158}$ Spoerer, Zwangsarbeit unter dem Hakenkreuz, 91-92.

${ }^{159}$ Ibid, 156-157; "Behandlung der Ukrainer aus dem Generalgouvernment im Deutschen Reiche," June 1942, Ukrainian Central Committee, p.392-3; "Behandlung der Ukrainer aus dem Generalgouvernement im Reich,” June 1942, Ukrainian Central Committee, p.394.

${ }^{160}$ Circular, Reichsfuihrer of the SS and Chief of the German Police, 18 July 1942, BArch R 58/1030, fol.180-6; Leaflet for Plant Managers, Plenipotentiary General for Labour Deployment, 17 July 1942, BArch R 3901/20288a, fol.40-51 also BArch NS 3/512, fol.328-337; Leaflet for Ostarbeiter, Plenipotentiary General for Labour Deployment, 17 July 1942, BArch NS 3/512, fol.341-3.
} 
had little to do with the actual deployment of ethnic Poles and Soviet citizens. Regulations specifically covering the deployment of Polish Ukrainians were non-existent, making their deployment trickier to track. Their regulations were based rather on the regulations for other foreign labourers as was the case before February 1942, with a few exceptions in regards to deployment in groups and their labour-law status.

Another significant 1942 program that brought thousands of Ukrainians to the Reich was the "Deployment of female labourers from the Old Soviet Realm."161 The program, which brought mostly Soviet Ukrainians to work as maids in German households, was an effort to impress on the population the advantages of winning in the East. It was also an attempt to relieve the burden of women, who had to deal with food shortages, their closest male family members fighting afar, and the prospect of compulsory service in industry. In another sign of the flexibility of race in Nazi Germany, Hitler summarily dismissed party objections to having female Untermenschen working in the homes of the Reich, stating that "we would have to revise our school knowledge about the great migration of peoples" because there were so many blond, blue-eyed Ukrainians who "might be the peasant descendants of Germanic tribes which had never migrated." ${ }^{162}$ The program contradicted Nazi racial ideology, and failed to solve any pressing need in the war economy or the domestic kitchens of the Reich. As Herbert explains, the program "was part of a political principle that, as far as foreigners were concerned, often appears more like a chain of contradictions and mistaken decisions than

\footnotetext{
${ }^{161}$ Decree, Reichsfïhrer of the SS and Chief of the German Police, 10 September 1942, BArch R 58/1030, fol.194-6.

${ }^{162}$ Memo on meeting at Plenipotentiary General for Labour Deployment, 3 September 1942, Doc. 25PS IMT vol. 25, p.84.
} 
a calculated political strategy." 163 In September 1942 it was decided to award party-loyal and child-rich families with their own maid, which soon became an upper-middle-class status symbol at an affordable price, and furthermore, the expression of a "quasi-colonial social order."164 Soviet Ukrainian and other Soviet females, seen as a subservient, subaltern population, were slotted for use by the "master race" to tend the sacred heart of the German nation, the home. Although the program had high recruitment goals, by the middle of August 1944 only 77,000 foreign maids had been assigned to German households, comprised equally of Soviet citizens and ethnic Poles. ${ }^{165}$ The unique deployment of Eastern Europeans in German households, as previously discussed, has been poorly examined in contemporary historiography, and therefore deserves special attention in the next chapter of this paper. The program is also notable as it marks a shift in the Nazi attitude toward Soviet Ukrainian and other Soviet labourers. Soviet citizens went from life behind barbed wire in factory camps, to a special deployment for some as maids in the homes of Nazi party elite. As the Wehrmacht fortunes in the Soviet East deteriorated, National Socialists began to change and liberalise their approach to the Untermenschen in the Reich.

\section{III: From 'Prisoners-of-Work' to fellow Fighters of Bolshevism}

The third and final phase of Ukrainian deployment in Nazi Germany can be described as one of contrasts. With the Wehrmacht defeat in February 1943 at Stalingrad, Nazi officials were forced to rely even more on Ukrainians, as the largest contingent of foreign labourers in the Reich. In a bid to improve productivity and gain their allegiance,

\footnotetext{
${ }^{163}$ Herbert, Hitler's Foreign Workers, 188.

164 Ibid.

${ }^{165}$ Spoerer, Zwangsarbeit unter dem Hakenkreuz, 120.
} 
the regulations guiding the day-to-day lives of Ukrainian labourers from both jurisdictions were overhauled drastically to meet the level of Western workers. The Plenipotentiary General for Labour Deployment together with the Reich Propaganda Ministry (Reichspropagandaministerium) banned the racist treatment of workers from the East and emphasised performance-based treatment. However, such changes took place in the face of ever-persistent allied bombing raids on the industrial centres of the Reich. Rather than being able to enjoy walking in the city centre without a German escort after one's shift, Soviet Ukrainians deployed to factories, for example, spent their evenings lying in hastily dug ditches, avoiding shrapnel and debris as their workplaces and barracks were targeted by air raids. Although the new regulations moved away from racial classifications, treatment based on race increased, with the Gestapo (secret police) taking complete control of policing Soviet and Polish labourers, and increased anger from the German populace aimed at foreign labourers in general as bombing raids destroyed urban infrastructure, law and order across the Reich. This final section focuses on these contradictions in racial ideology.

On 13 January 1943, with prospects for Wehrmacht victory in European Russian slimmer and slimmer, Hitler issued a secret Führer decree, declaring an official shift in Nazi state planning to a 'total war.' ${ }^{166}$ In order to further rally allied and neutral states, and further awaken support amongst Western powers, the National Socialists made a significant shift in their public justifications for the war, which would have some important implications in the treatment of Ukrainian labourers throughout the Reich. Ideas of Lebensraum and Untermenschen were officially wiped from government

\footnotetext{
${ }^{166}$ Willi A. Boelcke, ed., Wollt ihr den totalen Krieg? Die geheimen Goebbels-Konferenzen 1939-1943 (Stuttgart: Deutsche Verlags-Anstalt, 1967), 416.
} 
propaganda, with the war now justified as a German-led, but European-wide battle against Bolshevism. This major shift in state propaganda was announced 21 January 1943 by Goebbels in minutes of the "ministerial conference" for the German press held that day. In clarifying the new approach to the war in the East, Goebbels announced, "there is only one slogan that must be repeatedly proclaimed: our struggle against Bolshevism. Today, Russia is conducting its battle under the banner of nationalism, and so can rely on all parts of the nation for support. For that reason, our propaganda slogan in the East can only be that we are engaged in a struggle against Bolshevism, not Russian nationalism." 167 Coinciding with the change in official outlook of the war was a shift in the attitude toward Ukrainians and other Eastern Europeans. Harnessing the energy of a 30 January speech by Hitler emphasising the leading role of Germany in the protection of Europe against the Bolshevik danger, on 31 January the leader of the Propaganda Ministry's Eastern Department issued a statement outlining the new political line toward Eastern Europeans. The draft statement proclaimed that the Reich needed Eastern peoples as "important auxiliary labour." But in order for them to be won over to German interests, they would have to be correctly and decently treated. Taubert therefore proposed, that "the Führer's remarks on Europe's struggle against Bolshevism, the rescue of the continent by the German Wehrmacht, and the New Europe" should be put into an illustrated brochure. "The argument of this brochure should be that the European peoples must not forget everything that divides them. Family feuds must be deferred until after the war. Now the imperative is to keep the fire from consuming their common house."168 A further press conference on 12 February by Goebbels emphasised the difference

\footnotetext{
${ }^{167}$ Boelcke, Wollt ihr den totalen Krieg?, 424.

${ }^{168}$ Herbert, Hitler's Foreign Workers, 260.
} 
between 'Russians' and 'Bolsheviks.' There should be no talk of "a struggle against the Slavs or the Russian people," he wrote. ${ }^{169}$ Goebbel's 15 February 1943 decree finally spelled out the fundamental propaganda guidelines for the attitude to be taken vis-à-vis the peoples of the East:

All forces on the European continent, and thus especially of the Eastern peoples, must be mobilized for the struggle against Jewish Bolshevism. It is incompatible with this approach to denigrate these peoples, in particular members of the Eastern peoples, directly or indirectly, or to attack their self-image, especially in public speeches or published articles. These men and women from the East, who look to us for their liberation, cannot be termed beasts, barbarians, etc., and then be expected to have an interest in German victory. ${ }^{170}$

Such a drastic change in official state communication was a significant development in the attitude toward Ukrainian and other Eastern European labourers. Ukrainians, especially those from the Soviet Union, went from being one of the most maltreated nations to being part of a European-wide, common battle against Bolshevism. Using such terms as "colonies" or "colonial policy," or discussing plans about large-scale settlement and land expropriation in the East was prohibited. ${ }^{171}$ Instead, in a shift of policy intended to win the workers over to the German cause, officials began to speak out against the maltreatment of Eastern workers. In a 5 March statement, Goebbels decried the "poor treatment of workers from the East, male and female, in the Reich," an indication of changes to come. ${ }^{172}$

A month later, the Reich Main Security Office together with the Reich Propaganda Ministry compiled a leaflet regarding the "General Principles for the

\footnotetext{
${ }^{169}$ Boelcke, Wollt ihr den totalen Krieg?, 441-2.

${ }^{170}$ Secret Decree, 15 February 1943, BA R 58/459, fol.278.

${ }^{171}$ Ibid.

${ }^{172}$ Boelcke, Wollt ihr den totalen Krieg?, 451.
} 
Handling of Foreign Labourers in the Reich," which set the tone for treatment to the end of $1944 .{ }^{173}$ The leaflet, released 5 May 1943 internally by the Party Chancellery, was widely circulated, and had a broad impact. Created through cooperation between the Reich Main Security Office and the Reich Propaganda Ministry, the document balanced the Reich Main Security Office's ideologically-grounded demands for continued raciallybased treatment of Eastern European labourers and the Propaganda Ministry's desire to increase productivity and the fighting spirit of the entire resident population of the Reich. The preamble of the leaflet states, "[t]he top priority is the security of the Reich," reaffirming the role of the Reich Main Security Office in policing Eastern Europeans, but goes on to explain that, "[e]verything must be subordinated to the aim of final victory in the war." 174

One of the highlights of the official regulatory changes, which will be discussed more in depth in the next chapter of this study, was the statement that "each foreign labourer, where possible, will be placed in a position that makes the best use of his education and previous responsibilities." This was a shift from the previous policy that saw Ostarbeiter de-individualised and deployed mostly en masse, regardless of the particular skills and training they brought from the Soviet Union. ${ }^{175}$ Further statements called for "orderly, clean and hygienic" accommodations, with "barriers and barbed wire" forbidden. Food rations were to be brought up to the level of Germans, a right to "effective healthcare" was announced, and Ostarbeiter were finally permitted to leave their camps during their free time. Ukrainians and other foreign workers were therefore more free, at least on paper, than at any time during their stay in the Reich. The defeat at

${ }^{173}$ Circular letter from Party Chancellery, 5 May 1943, Doc 205PS IMT Vol.25, pp.298.

${ }^{174}$ See Circular letter from Party Chancellery, 5 May 1943, Doc 205PS IMT Vol.25, pp.298.

${ }^{175}$ Ibid. 
Stalingrad, marking a broader change in Wehrmacht war fortunes, meant that Nazi racialpolitical ideology was officially relaxed by labour officials, as German business and agriculture tried to win their Ukrainian and other foreign labourers over to the struggle against Bolshevism.

\section{III: Soaring Recruitment, the Vlasov Amendments and Air Raids}

The third phase of Ukrainian labourer deployment in Nazi Germany not only saw a significant easing in restrictions, aimed at increasing the productivity of Ostarbeiter, it also saw the largest recruitment of Ukrainian workers. With the defeat at Stalingrad, the Wehrmacht turned all scruples to the wind and increased the level of terror on the native population in its Occupied Eastern Territories. Recruitment therefore became more and more severe. Despite the changing tide of war and the inability to meet ambitious goals set by Sauckel, Nazi labour officials still managed to recruit a stunning 2.5 million new workers; so many that half the Soviet labourers in the Reich at the end of the War arrived after Stalingrad. ${ }^{176}$

In order to increase war production, and freed by the 15 April 1943 regulation changes from employing Soviet Ukrainians without regard to skills and training, this final phase of the Ukrainian labourer deployment also saw a move toward productivity. In spring 1943, the DAF and Plenipotentiary General for Labour Deployment collaborated on a project to increase performance by more effectively deploying labourers in lines with their training and experience, and ensuring workers were properly treated. ${ }^{177} \mathrm{~A}$

\footnotetext{
${ }^{176}$ Herbert, Hitler's Foreign Workers, 281, 286.

${ }^{177}$ Decree, Plenipotentiary General for Labour Deployment to Labour Offices, 1 April 1943, BArch R 58/1030, fol.205.
} 
result of these endeavours was a more concerted effort to increase the level of on-site training, and increase the level of skilled deployment of Ostarbeiter and Poles.

Decreasing war fortunes created even further demand to ameliorate the treatment of Eastern European workers. In June 1943, the Reich Main Security Office changed regulations regarding the identifying badges for Ostarbeiter and Poles based on performance, which were changed one year later to finally allow for badges identifying Soviet labourers based on their ethnic identity, rather than the more generalised "OST" badge, which will be explored more thoroughly in chapter three. Nineteen Forty-Four saw the further lifting of restrictions, with the equalisation of Polish and Ostarbeiter wages on 14 February. The final lifting of discriminatory restrictions regulating the lives of Ukrainians took place in December, on the request of General Andriy Vlasov, a Red Army Officer defector who the Nazis permitted to form the Russian Liberation Army in their battle against the Soviet Union. Vlasov demanded full equality with the other foreigners with respect to food, housing, wages, taxes and clothing, and a "prohibition on violence and humiliating punishment" for his fellow countrymen and -women. ${ }^{178}$ Soviet Ukrainians were subsequently given the same rights and responsibilities as their fellow nationals from Occupied Poland, and other labourers from across Europe, the last such policy move before discussions surrounding the treatment of Eastern Europeans ended in January 1945 with the commencement of the Soviet Vistula-Oder offensive. However, the full status of a Western European labourer was never fully achieved. The only significant change in practice to be fully implemented was the move toward deployment based on one's skills and education. As will be discussed in the third chapter when

\footnotetext{
${ }^{178}$ Herbert, Hitler's Foreign Workers, 294.
} 
exploring the actual day-to-day life of Ukrainian labourers in the Reich, racial motivations still guided treatment, as fought for by the Reich Main Security Office. "To abandon 'racially' underpinned differences in treatment," Herbert writes, "would have entailed a wholesale loss of ideological-philosophical identity, and a forfeiture of key elements in the Nazi political program."179 The ideological foundation of the Nazi regime, developed, moulded and sold to the population over a period of ten years, would be incredibly difficult to abandon. The situation on the ground for Ukrainian labourers was different than the situation dictated in government decrees and regulations, marking a failure of Nazi officials to understand the social realities of a country under constant attack.

The final phase of the war, as previously mentioned, was also marked by the destruction of Germany's urban centres, leaving many Ukrainians homeless. With the deterioration of supply chains to feed damaged factory assembly lines, as well as the mouths of the factory line workers, many Ukrainians and other foreign workers were forced to feed themselves through looting and stealing. Denied room in public air raid shelters, actual air raids provided opportune times to obtain food for a meal, with apartments and houses emptied of their inhabitants. Ukrainian and other foreign labourers therefore quickly became scapegoats for the decrease in urban order that the bombing raids caused. The creation of gangs of foreigners, reported already in July 1944, was met with heavy reprisals. ${ }^{180}$ One month later, an SS leader responsible for Western Germany

\footnotetext{
${ }^{179}$ Herbert, Hitler's Foreign Workers, 295.

${ }^{180} \mathrm{Ibid}, 364$.
} 
proclaimed that firearms were to be ruthlessly used on looters, workplace deserters, and saboteurs. ${ }^{181}$

The final months of war were an apocalyptic end to the Reichseinsatz. Remaining SS personnel massacred Ostarbeiter gangs en masse in March and April 1945, as the Ruhr Valley was encircled by American and British troops. ${ }^{182}$ The situation in the countryside was similarly chaotic, with highways and country roads full of Ukrainian and other foreign labourers forced to flee to the centre of the country. In one case, in the hamlet of Warstein, half-way between Düsseldorf and Kassel, the local SS General became annoyed with foreign workers causing traffic jams by clogging the roads, and felt threatened by Soviet workers who he thought would need to prove their anti-fascist credentials in order to return the Union after the war. During the last week of March 1945, SS General Kammler had a group of soldiers enter the local shooting hall, which had been converted into an emergency foreign labour reception camp, and asked for volunteers to change camps. All of those who came forward to transfer were Ostarbeiter, in total, 56 women, 14 men and one six-year-old child. They were loaded onto a truck, taken to a nearby valley, executed, and buried in a mass grave. The process was repeated two more times in the following days, and a total of at least 208 persons from the Soviet Union were slaughtered. The following week, on 7 April 1945, Warstein was liberated by American troops. ${ }^{183}$ Such an incident shows the chaos that reigned in the Reich during the final weeks of the war. It also proves that despite the numerous statements on the importance of all foreign workers in the "struggle against Bolshevism," and the change in

\footnotetext{
${ }^{181}$ Adelheid L. Rüter-Ehlermann and C.F. Rüter, eds., Justiz und NS-Verbrechen, IX, No.301 (Amsterdam: Amsterdam University Press, 1968-), 301-2.

${ }^{182}$ Rüter-Ehlermann and Rüter, Justiz und NS-Verbrechen, XV, No.474; Ibid, XV, No.474 Burgholz Case II, 272.

${ }_{183}$ Ibid XVI, No.486; Ibid XVII, No.508: Ibid XVIII, No.530.
} 
regulations making Soviet Ukrainians and other Soviet workers equal to Polish Ukrainians and other European labourers, the situation on the ground was much different. Years of anti-Soviet propaganda had made an impact on Nazi officials and the German population. in spite of the ban on referring to "colonial" goals in Eastern Europe, many still believed that the lands of Poland and the Soviet Union would one day form German Lebensraum. Combined with war exigencies that made the implementation of such policy reversal increasingly difficult, Ukrainian labourers, especially industrial, did not benefit a great deal by the changes in regulations and official relaxation of Nazi ideology in the last phase of deployment.

Throughout the different phases of Ukrainian deployment a few trends can be identified. The first Ukrainian labourers to enter the Reich from both Occupied Poland and the Occupied Soviet Union were not civilians, but rather prisoners-of-war, who in both cases were released directly before or directly after entering the Reich, owing to their ethnicity vis-à-vis the larger, more stigmatised groups Poles and Soviet Russians. Nazi labour officials used their initial experiences with the of Poles as a blueprint when deciding how to regulate the deployment of Soviet citizens. Both ethnic Poles and Soviet citizens experienced blatant racism and general subjugation to other national groups in Germany. Polish Ukrainians, however, were always considered distinct in the eyes of labour officials and Nazi ideologues, due to their historical ties with the AustroHungarian Empire, and were always placed higher in the racial-political hierarchy. Furthermore, in both jurisdictions, reports from Ukrainians already in Germany combined with the violent and terrorising recruitment techniques caused voluntary recruitment 
levels to evaporate, necessitating even more extreme tactics, and further complicating the administration of the occupied areas. While National Socialist racial-political ideology was gradually applied more liberally to Ukrainian and other foreign labourers as Germany's war fortunes changed, Ukrainians on the ground saw few changes. The postStalingrad policy changes of 1943 to the official Nazi approach to the war had little impact, both in the Occupied East where recruitment techniques became only more brutal, and within the boundaries of the Reich, which was being increasingly weakened by allied bombing raids. The racist and colonial Nazi ideology that was used by the upper echelons of the German state to justify the war was relaxed, but not fully forgotten. Rather than a fundamental re-writing of anti-Slavic racial policy, Nazi officials simply changed the tone, and the way in which it was applied. 


\section{Chapter 3 - The Ukrainian Everyday in Nazi Germany}

We were divided up and sent to various camps. There are 31 persons in the barracks. We girls go to work in a closed group...The German soldiers were full of praise for how beautiful it was in Germany. But there's nothing more beautiful than life back home... it's so beautiful that we cry every day, every hour, just thinking of home. At home all there was was soup and bread, but we're no better off here than pigs. Give everyone our best regards. We get a daily ration of soup, 300 grams of bread and 15 grams of butter, and tea twice a day. But it's only a ladleful of soup...So we're suffering. It rains every day...We were thinking about death and don't think we'll ever see you again. Back home, we were scared of the artillery shells. Here people are going hungry and it's worse than it was at home. Dear relatives, we live in barracks, each one surrounded by a fence, it's like being in jail, and the gate is shut...We're not allowed to go out anywhere...We get up at 5 a.m. and go to work at seven. We finish 5 p.m. ${ }^{184}$

This letter, written by two female Ostarbeiter deployed to a factory in Berlin in

1942 , is telling, and hints of the everyday life that Ukrainian labourers, especially Soviet Ukrainians, led during their time in the Reich. The treatment and everyday experience of Ukrainian labourers in the Reich, the topic of this chapter, was influenced by a number of variables. As discussed in chapter one, through a higher status in the Nazi racial-political hierarchy, Polish Ukrainians in the Reich received favourable treatment compared to their fellow nationals from the Soviet Union, labelled Untermenschen, or 'subhumans,' and treated as such. Treatment also varied depending on the nature of deployment. Those deployed to industry and large farms often worked in large groups with fellow citizens from their home countries, and were subject to somewhat harsher, de-individualised treatment. Those deployed to private farmsteads and households were generally treated better, receiving at the bare minimum a more steady supply of food than those in industry, particularly in the third phase of Ukrainian labourer deployment (1943-1945),

\footnotetext{
${ }^{184}$ Translated letter intercepted by Post Censorship Bureau, 10 August 1942, BArch R 3901/20269, fol.176.
} 
as cities and supply chains crippled from allied air raids. As explored in chapter two, the regulations and decrees guiding the everyday lives of Ukrainian labourers evolved closely following the Wehrmacht performance on the front. The defeat at Stalingrad, in particular, led to a reversal in the official tone toward Soviet Ukrainian and other foreign labourers, away from notions of Untermenschen, toward a common European fight against Bolshevism. Despite such policy changes in Nazi officialdom, and despite the vast array of deployments, from mines in the Ruhr valley to villas in the suburbs of Berlin, the situation on the ground saw a continued treatment based on race and history prevail. The racist and colonial ideologies and policies that justified German expansion into Eastern Europe were not modified or adjusted. Rather their tone changed. Ukrainians, regardless of whether they originated from Poland or the Soviet Union, were a subjugated people during their stay in Germany. They were consistently looked down upon as inferior residents of the Reich, and viewed as part of a massive labour population, in place to serve the needs of the German people.

The experience of Ukrainian labourers in the Reich started with their recruitment in the villages and cities of occupied Poland and Soviet Ukraine, and ended with the end of the war. This chapter is broken up into four sections to capture different aspects of the everyday experience of Ukrainian labourers in Nazi Germany. The first section deals with the recruitment process in the Generalgouvernement and Reichskommissariat Ukraine, as well as the journey to the Reich. It includes a discussion of the racial screening that took place for some recruits, the role of the Ukrainischer Hauptausschuss (UHA, Ukrainian Central Committee, Ukraïns'kyi Tsentral'nyi Komitet), and refers to some rich documents from the UHA that shed light on the inhumane return journey of 
sick or injured workers, emphasising the racial-political treatment of Ukrainians. As the scope and geographical breadth of the war expanded, and Nazi labour needs continued to grow, German labour officials were forced to re-examine their recruitment techniques and shipment of 'recruits' to the Reich, and in some cases, take a step back from the harsh racial ideology that guided the initial advances into the Soviet Union.

The second section addresses the everyday living conditions of Ukrainian labourers in Nazi Germany, and includes discussions of conditions guiding deployment, accommodation/food/clothing, surveillance, and wages/pay. The derogatory badge system for Ostarbeiter, adding to the discussion of badges for ethnic Polish workers in chapter two, will be explained in this section, as will a special skills training program for Polish-Ukrainians. The third section deals with the nuances to life in Germany. Centred on the general topic of free time, it touches on recreational activities, and includes some novel findings on the celebration of holidays, and popular religion. The deteriorating fortunes of the Wehrmacht on the Eastern front, and the ever-increasing importance of Ukrainian labourers to German industry, meant that their treatment officially improved, and Nazi racial ideology emphasised less. The fourth and final section is a case study of one kind of deployment in Germany, and captures the unique but often forgotten use of Soviet females as maids in German households. The case study shows the contradictions in Nazi racial policy, exploring a program that saw members of one of Germany's most hated 'races' tending the hearths and baby cradles for the most loyal of Nazi party members. Each section tracks major policy and regulation changes, and uses first-hand accounts to determine what sort of impact, if any, such changes had. 
The framework for discussions of everyday life in Germany are the specific decrees and regulations released by the Reich Main Security Office (Reichssicherheitshauptamt), the Plenipotentiary General for Labour Deployment (Generalbevollmächtigter für den Arbeitseinsatz) and the Reich Propaganda Ministry (Reichspropagandaministerium), as introduced in chapter two, including the Polererlasse (Decrees for Poles) of 8 March 1940, the "General Conditions" of 20 February 1942, and as a result of the defeat at Stalingrad, the 5 May 1943 "General Principles" leaflet. Documents of the Ukrainischer Hauptausschuss serve as a particularly rich source of information on the actual conditions in the Reich, a source that is seldom cited in contemporary historiography. First hand accounts, in the form of memoirs and interviews, also play a significant role in this chapter. Together, these sources paint the picture of a flexible and limited Nazi racial policy, which was changed and adapted by Nazi officials given the realities of waging a war and sustaining the war effort.

\section{I: Recruitment}

Acquiring sufficient manpower to fuel the German economy was a goal that stretched beyond the establishment of the National Socialist state. As discussed in the first chapter, Germany, and its predecessor Prussia, had dealt with labour shortages since the latter nineteenth-century. This first section addresses how Nazi officials recruited Ukrainians from both Occupied Poland and Soviet Ukraine, including how they processed and shipped them to the Reich. The first part explains the recruitment process, including the intensive quotas, while the second deals with racial screening and their animal-like treatment during their journey to Germany. A discussion of the recruitment 
and transportation methods reveals a dirty cycle in this first step of the labour experience. The racially-driven form of transportation and treatment along the way, combined with even worse conditions for those recruits and labourers forced to return home, opened the eyes of ethnic Ukrainians to what they could expect from deployment in the Reich. This caused volunteer numbers to dry up, necessitating harsher recruitment methods and further impressing on the Ukrainian population their subordinate status vis-à-vis the Germans.

While the invasions of Poland, and later Western and Northern Europe, strained the German labour market, as conscripted German men were taken from factories and farms across the Reich and sent to the German front lines, it was the 1941 invasion of the Soviet Union that caused the most critical labour situation. The dramatic Battle of Stalingrad, from July 1942 to February 1943, and a pressing need to increase armaments and ammunitions output, created the conditions for the most intense labour recruitment effort conducted by Germany during the war. Fritz Sauckel, Plenipotentiary General for Labour Deployment (Generalbevollmächtigter für den Arbeitseinsatz), set his targets in Reichskommissariat Ukraine, German-occupied Soviet Ukraine, quite high: 225,000 workers in the last three months of 1942, and another 225,000 in the first four months of 1943. Furthermore, from 15 March 1943 Sauckel demanded that three thousand workers be recruited daily, a number later doubled to six thousand per day. ${ }^{185}$ Quotas for Polish Ukrainians in the Generalgouvernement were similarly high, with 200,000 in the first three months of $1943 .^{186}$

\footnotetext{
${ }^{185}$ Berkhoff, Harvest of Despair, 259.

${ }^{186}$ Note for Files, Meeting between Generalgouvernement Department of Labour leader and Ukrainischer Hauptauschuss, 7 May 1943, Ukrainian Central Committee, p.546-9.
} 
Attempts to recruit Ukrainian labourers were further hampered by the already low number of men remaining in the territories. Most able-bodied men had already been recruited elsewhere, most into either the Red or Polish armies. In the case of captured Ukrainians in the Polish army, the Wehrmacht shipped them to the Reich, where they were reclassified as 'civilian' labourers, as was touched upon in chapter two. Other males were recruited to the native Order Police, an SS-led police force found in both the Generalgouvernement and Reichskommissariat Ukraine, responsible for assisting the occupation authorities in keeping peace and fighting partisans. Still others served as administrators, or fled eastward, both voluntarily and forcibly, with the fleeing Red Army in 1941. Generally, labour officials recruited any able-bodied person they could apprehend, but a lack of available men meant that the minimum age for recruitment was ever falling. In 1943 in the Generalgouvernement, all those 24 to 26 years-of-age were obligated to work in the Reich. ${ }^{187}$ Already in $1942,49 \%$ of workers from the Soviet territories in Germany were under the age of $18 .{ }^{188}$ The only recruitment program to indicate a specific age-range was the deployment of Soviet citizens to German households as maids, which stipulated that recruits could only be between 15 and 35 years of age. ${ }^{189}$

In order to attract Ukrainians from the towns and villages of occupied Poland and Soviet Ukraine to the farms and factories of the Reich, German labour officials utilised widespread recruitment campaigns. The recruitment of civilian Ukrainians in the former Soviet territories, including Białystok County and the District of L'viv, was performed by

\footnotetext{
${ }^{187}$ Notes for Files, Meeting between Generalgouvernement Department of Labour leader and Ukrainischer Hauptauschuss, 7 May 1943, Ukrainian Central Committee, p.546-9.

${ }_{188}^{10}$ August 1942, BArch R 3901/20270, fol.4.

${ }^{189}$ Decree, Reichsfiuhrer of the SS and Chief of the German Police, 10 September 1942, BArch R 58/1030, fol.194-6.
} 
Recruitment Commissions of the Reich Labour Ministry, while in the Generalgouvernement, Labour Deployment Posts (usually the local Labour Office) were used. ${ }^{190}$ The labour authorities in occupied Soviet Ukraine modelled their recruitment procedure on experiences in occupied Poland. Labour authorities set quotas for each county, which were then divided up amongst the towns and villages. The municipal administration was then responsible for deciding who would be conscripted, sending out deployment notices in the post. ${ }^{191}$ The recruitment campaign that began in 1942 in Reichskommissariat Ukraine included the publication of information in newspapers, leaflets, brochures, brightly-coloured posters, and an itinerant exhibition. The campaign stressed numerous benefits of working in the Reich, including the development of skills, the possibility of saving money, the promise of receiving land in Ukraine once the war was won, and access to free housing and medical care. The underlying message of the materials was optimism and opportunism. One poster stressed the experience as an escape from life under Stalin, and a chance to open one's eyes to what had happened in Europe since Stalin had consumed much of Ukraine. "Who of us, Ukrainians," it asked, "would have thought that we would be asked whether we would like to work in Germany? Only now do we, who accepted that offer and are living in Germany, understand why Stalin erected a wall around us and why he did everything to prevent us from finding out what was happening over the last ten years in Germany, the land of true socialism." 192 One recruit from southern Ukraine recalled posters promising, "the volunteer workers were to receive the same salary, the same food rations, the same

\footnotetext{
${ }^{190}$ Decree, Reichsfithrer of the SS and Chief of the German Police, 20 February 1942, BArch R 3901/20481, fol.58-70.

${ }_{191}^{191}$ Herbert, Hitler's Foreign Workers, 81, 83.

${ }^{192}$ Berkhoff, Harvest of Despair, 254.
} 
accommodations as German citizens," and would "be free to return after the war's end," or, if they chose, "they could remain in Europe." 193 But as was hinted to at the start of this chapter, and as will be discussed in the coming pages, the actual conditions that Ukrainian labourers faced were much different than what was presented, especially for Soviet Ukrainians.

Nonetheless, the propaganda campaign initially met with success. In Kiev, for example, thousands signed up for work in January, leaving on a train to the sound of a brass band. ${ }^{194}$ Despite the extent and all-pervasiveness of the German propaganda, however, few Ukrainians bought into it, and by mid-1942, volunteer numbers dried up. ${ }^{195}$ One reason was the humiliation they suffered during the recruitment process, and the stories they heard from returning recruits. ${ }^{196}$ According to a September 1942 report of the Central Office for Members of the Eastern Peoples (Zentralstelle für Angehörige der Ostvölker or ZAO), habitually five percent of the eastern workers arriving in Germany during the preceding six months were pregnant, sick, too old or crippled that they had to go to a 'Return Camp' in Berlin, from which they were shipped back East as unfit. ${ }^{197}$ This number was particularly high, considering that only able-bodied Ukrainians were to be recruited, and pass a medical examination before entering the Reich borders, and hints toward the ruthlessness with which recruitment took place. Ukrainians who had fallen ill, had had an accident, or had become disabled during Allied bombardments were also put on eastbound cargo trains without any food or medical assistance. Many died, and those

\footnotetext{
193 Nina Markovna, Nina's Journey (Washington: Regnery Gateway, 1989), 245.

${ }^{194}$ Berkhoff, Harvest of Despair, 255.

195 Ibid, 256.

${ }^{196}$ Berkhoff, Harvest of Despair, 256; Dallin, German Policy in Russia, 430.

${ }^{197}$ Reitlinger, The House Built on Sand: The Conflicts of German Policy in Russia 1939-1945 (London: Widenfeld and Nicolson, 1960), 268-9.
} 
remaining spread the word. Ukrainians quickly associated deployment in the Reich with maltreatment, sickness, lies and terror, and sought to avoid it at all costs. ${ }^{198}$

With falling volunteer rates, conflicts arose between Sauckel, who faced increased demands from Nazi officials and German big business to get thousands of new workers into armament and munitions factories, and Wehrmacht leadership, who saw the effects of forced recruitment on the front lines, namely in the rise of partisan activity. Internal Wehrmacht memos from 1942 emphasise the importance of recruiting labourers voluntarily, "to avoid adverse consequences on the attitude of the population living on the front lines." ${ }^{199}$ In August 1942, the Plenipotentiary General for Labour Deployment, along with the Wehrmacht and Reichsminister für den besetzten Ostgebiete (Reich Minister for occupied East) approved the use of force, but only "in specific exceptional cases. ${ }^{200}$ Recruitment officials, often Ukrainians recruited to the local Order Police, were only permitted to use force when volunteer recruitment was not successful, with the exact kind of force to be determined through the Plenipotentiary General for Labour Deployment and the Wehrmacht leadership.

However, with such extreme recruitment quotas, the use of force became inevitable. In a January 1943 'note for the files,' Ukrainischer Hauptausschuss leader Volodymyr Kubijovyč reported that while in some counties of Galicia, recruitment was taking place in an orderly fashion with few complaints, in many others, the process had turned into a mass manhunt. ${ }^{201}$ Cases were reported, "in which the police appear in villages at night, and anyone who falls in their hands is taken...Mothers and fathers are

\footnotetext{
${ }_{198}^{198}$ Berkhoff, Harvest of Despair, 258-9; Dallin, German Policy in Russia, 175.

${ }^{199}$ Memo, Wehrmacht Oberleutnant Pillhausen, 5 June 1942, BArch R 3901/20269, fol.171.

${ }^{200}$ Memo, Reichsminister for the Occupied East to Reichskommissaren for Ukraine and Ostland, 12 October 1942, BArch R 3901/20270, fol.24.

${ }^{201}$ Note for the Archives, Kubijovyč, 13 January 1943, Ukrainian Central Committee, p.479.
} 
regularly taken away from their children, while sick and invalid people are sent away."202 One Soviet Ukrainian labourer commented that, "young women like me are just picked off the street or out of their homes and shipped to Germany," proving that Ukrainians in both jurisdictions were regularly and indiscriminately apprehended in towns from public places. ${ }^{203}$ The UHA report further cites a case in Biała Podlaska in which Labour Office employees went to a Ukrainian Business School to capture students, causing them to flee through windows from the blockaded lecture halls. Round-ups of Ukrainian students from high schools and institutes were reported by the Hauptauschuss throughout the Generalgouvernement, a procedure that was not possible in occupied Soviet Ukraine, due to the closure of most educational facilities beyond primary school. ${ }^{204}$ One labourer recalled being rounded up with other young Ukrainians while attending Sunday mass. ${ }^{205}$

And in an interesting official change in approach in the treatment of Ukrainian labourers, as pronouncements in the Reich were extolling the common struggle against Bolshevism, and raising Ukrainians' rights and privileges to the level of Western labourers, the recruitment policy in the Occupied East became even more brutal. In April 1943 , the shift to and reliance on forced recruitment was finally acknowledged, and even encouraged by the central authorities. ${ }^{206}$ Responding to complaints from the Ostministerium (Eastern Ministry) that houses were being burned in connection with the recruitment of labourers, a regional commissioner replied, "referring to the special urgency of recruitment for the Reich, a decree of the Commissioner-General in Luzk,

\footnotetext{
${ }^{202}$ Note for the Archives, Kubijovyč, 13 January 1943, Ukrainian Central Committee, p.479.

${ }^{203}$ George and Janssen, Goodbye is not forever, 77-8; Note for the Archives, Kubijovyč, 13 January 1943, Ukrainian Central Committee, p.479.

${ }^{204}$ Note for the Archives, Kubijovyč, 13 January 1943, Ukrainian Central Committee, p.479-81.

${ }^{205}$ Makuch, "My Life," 2.

${ }^{206}$ Meldungen aus dem Reich, Reich Security Police, 19 April 1943, BArch R 58/182, fol.120-2.
} 
dated 31 September 1942, specifically states that 'the farms of persons who refuse to work should be burned down, their relatives taken hostage and placed in forced labour camps. "207 The treatment of Ukrainians during the recruitment process, despite the changes in policy in Berlin, was still marked by violent, heavy-handed overtones. The more severe the losses on the front lines were, the more severe the recruitment process became.

One of the most significant transfers of people in 1943 took place on the heels of the approaching Red Army as part the forced evacuation from the Left Bank of the Dnieper River. Along with livestock and machinery, the retreating Wehrmacht took all able-bodied civilians, while anything remaining was to be destroyed as part of a "scorched earth" policy of Erich Koch, Reichskommissar for Ukraine. ${ }^{208}$ The evacuation had limited success. While the Wehrmacht reported the evacuation of ten percent of the population, or some 600,000 people, guards at the Dnieper bridges counted only $375,000 .^{209}$ Nonetheless, a sizable group of Ukrainians fled the advancing Soviet forces, and later joined fellow nationals in Germany. These labourers, together with other Soviet Ukrainians 'recruited' by ever-more terrorising methods after the defeat at Stalingrad, made the final phase of the war the largest input period of Soviet labour, as discussed in chapter two. A remarkable $50 \%$ of the Soviet workers present in Germany at the end of the war arrived after February 1943. ${ }^{210}$

\section{I: Journey to the Reich}

\footnotetext{
${ }^{207}$ Herbert, Hitler's Foreign Workers, 280.

${ }^{208}$ Report by District Commissioner Steudel on German Retreat from District of Kasatin between 8 November and 28 December 1943, IMT 1702-PS, Vol. XXVII, p.463; Berkhoff, Harvest of Despair, 300. ${ }^{209}$ Berkhoff, Harvest of Despair, 300.

${ }^{210}$ Herbert, Hitler's Foreign Workers, 281.
} 
The journey to the Reich started in the towns, villages and cities of the Occupied East. New recruits first reported to local labour officials, where they could be assembled in smaller groups and sent to a larger regional reception camps. Those recruits taken against their will began their journey in local community centres or schools, in which they were held until transport to the reception camps. ${ }^{211}$ As one labourer from the Reichskommissariat Ukraine region of Khmelnytskyi recalled, after being shipped by horse carriage from her hometown, she and fellow recruits, "were locked there [in the town of Starokonstantinov] in the barracks, and the young people were brought there from the whole area. This was not long, about a week. The young people were brought there, all of us were then forced to go to the train station., ${ }^{, 212}$ The erection of such larger regional reception camps was the responsibility of the Reich Ministry of Labour Recruitment Commissions, which they sometimes delegated to the Ukrainian Work Service. ${ }^{213}$ Here recruits underwent a medical examination by Reichsdeutsche and their first in a series of delousing treatments. ${ }^{214}$ Special racial inspections were only conducted for recruits targeted for the housemaid program, which will be explored further below.

The SS and labour officials did not otherwise conduct racial screening for citizens from within the pre-September 1939 Soviet boundaries, who were seen by Nazi ideologues as a mass of oppressed Bolshevik enemies. However, in the former Soviet territories, including Białystok County and the District of L'viv, special commandos of the Security Police and Sicherheitsdienst (Security Service) were responsible for political

\footnotetext{
${ }^{211}$ Makuch, "My Life," 2.

212 Billstein, Working for the Enemy, 169.

${ }^{213}$ Note, Head of Armaments Delivery Office to Ministerial Advisor Dr. Letsch, 8 December 1942, BArch R 3901/20270, fol.129

${ }^{214}$ Decree, Reichsfiihrer of the SS and Chief of the German Police, 20 February 1942, BArch R $3901 / 20481$, fol.58-70
} 
screening, to weed out "particularly dangerous elements," which presumably refers to communist organisers and other former Soviet officials who had aided in bringing Soviet rule to Western Galicia and Białystok County. ${ }^{215}$ As had been the case since 1939, ethnic Ukrainian and other ethnic minority workers from the Generalgouvernement would continue to be marked as such in their papers with the new regulations of February 1942, introduced with the deployment of Soviet citizens to the Reich.

While the regulations called for the elimination of the role of the Byelorussian, Russian and Ukrainian Vertrauensstellen (Trust Authorities) in the caring for their ethnic nationals from the Generalgouvernement in the Reich, this practice clearly continued, as evidenced in the intervention of the Ukrainische Vertrauensstelle in reclassifying one labourer as "Ukrainian" from ethnic Polish. ${ }^{216}$ The continued functioning of the Vertrauenstellen was a curious situation, a likely result of the recognition by Nazi officials of their role in continually splintering the population of the Generalgouvernement, since Poles were not permitted to form such organs.

Racial undertones guided the behaviour of Nazi officials, and also influenced behaviour between groups of Eastern Europeans, especially in the Generalgouvernement, rich with ethnic tensions. The surveillance of the reception camps was to be arranged by the Commander of the local native Order Police in cooperation with the Recruitment Commission. Archival evidence shows that the ethnic Polish members of the Order Police in reception camps were sometimes excessively harsh in treating freshly recruited Ukrainian labourers. In a meeting between the Ukrainischer Hauptauschuss (UHA) and the Leader of the Generalgouvernement Labour Department, UHA leader Kubijovyč

${ }^{215}$ Decree, Reichsfiihrer of the SS and Chief of the German Police, 20 February 1942, BArch R 3901/20481, fol.58-70

${ }^{216}$ Makuch, "My Life," 3. 
apparently raised the issue of mistreatment at the hands of the predominantly Polish Order Police. ${ }^{217}$ A ministerial aide replied that it would be possible to replace the ethnic Polish camp personnel with Ukrainians appointed by the UHA, especially in camps for women, which indicates that men and women were held in different reception camps. There also appear attempts by both parties to make the temporary residency in the reception camps more comfortable; the UHA reported that concerts and lectures were given from time to time, and that it was preparing to release a brochure with instructions for labourers heading to the Reich. The occupation administration also planned to show the Wochenschau, a weekly propaganda news reel. ${ }^{218}$ Whether such attempts to improve the stay in the reception camps ever materialised is unknown.

According to the regulations of February 1942, both Polish and Soviet Ukrainians were to be sent to the Reich in "enclosed transports," which in reality, meant railroad freight and cattle cars. Whereas transports of Polish Ukrainians, usually mixed with other Polish citizens, were not to be guarded, Soviet Ukrainians were to have guards organised by the native Order Police. ${ }^{219}$ The use of such inhumane means to transport labourers was remembered by many as shocking and demoralising, with many making allusions to their treatment as animals. In some ways, such treatment was only a hint of the treatment Ukrainian labourers could expect in the Reich, and the low value placed on their lives. The train journey became a foundational memory, as one of the initial steps of the labour experience and their wartime existence in Germany. One labourer described the cramming of sixty or more girls into each wagon, commenting, "we were transported not

\footnotetext{
${ }^{217}$ Notes for Files, Meeting between Generalgouvernement Department of Labour leader and Ukrainischer Hauptauschuss, 7 May 1943, Ukrainian Central Committee, p.546-9.

${ }^{218}$ Ibid.

${ }^{219}$ Decree, Reichsfïhrer of the SS and Chief of the German Police, 20 February 1942, BArch R 3901/20481, fol.58-70
} 
like working hands but rather like goods or cattle." 220 Another labourer recalled being packed with fifty Ukrainians into one car, and having to sleep on the floor. ${ }^{221}$ A labourer from southern Ukraine described his first glimpse of the family's transportation to the Reich: "a string of cattle cars too long to count. The shock of the sight hit all of us like a physical blow, as if to emphasize it, the Germans were now herding us along, cramming as many as possible into each car, then closing the door and bolting it shut from the outside, and moving us on to the next." 222 Conditions in the trains were made worse by meagre food rations, lack of sanitary facilities, sweltering heat in the summer, blistering cold in the winter, and often a lack of personal provisions, due to the hastiness of many labourers deployment.

Ostensibly in order to maintain German standards of hygiene and cleanliness, and avoid the spread of disease from East to West, every Ukrainian labourer was given a cursory medical inspection and deloused at least twice; Soviet Ukrainians were inspected upon entering the Generalgouvernement at one of sixteen reception camps, while Polish Ukrainians were inspected upon leaving it (usually at the same reception camps that 'welcomed' Soviet citizens to the Großdeutsches Reich), while all labourers from Eastern Europe were inspected at one of twenty-eight transit camps upon reaching the Reich proper. $^{223}$ The repeated inspections and delousing procedures only added to the sadness and humiliation that hung over the labourers as they were transported further and further from their homelands. One labourer from southern Ukraine recalled that the various delousing stations along the way caused a "gloomy, dark mood" to settle over many who

${ }^{220}$ Khelemendyk, Kolkohz Childhood and German Slavery, 102.

${ }^{221}$ Fedir Telka, Interview by Stephen C. Telka (April 11 2005).

${ }^{222}$ Basansky, Escape from Terror, 153.

${ }^{223}$ Memo, Reich Security Office to Security Police Inspectors, State Police Offices, Reich Labour Ministry, 6 February 1942, BArch R 581030, fol.161-6. 
had been excited about working in Germany. "Our reception in Przemsyl," he wrote, "somehow did not correspond to the rosy promises in Feodosia's [recruitment] posters."224 Those who were deemed healthy were deployed; Polish Ukrainians were picked up by company or farm personnel, while Soviet Ukrainians were picked up by armed guards. ${ }^{225}$ One Polish-Ukrainian labourer deployed to a farm in Württemberg recalled feeling further humiliated upon being deployed, writing, "[a] farmer picked me up from the main office-working bureau. The Nazi had a bike and I walked behind himonly eight kilometres like a calf after his mama cow."226

Those deemed at the medical inspection centres as unfit to work in Germany upon entering the Reich, for example due to pregnancy, injury, illness, or old age, were sent home, at least until late 1942. Return transports, as discussed below, had a negative impact on recruitment in the Occupied East. The conditions of such return transports was even more appalling than the initial journey to the Reich, the result of Germany being stretched thin, and seeing little value in caring for such groups of people. In a June 1942 letter from the Przeworsk Committee of the Ukrainischer Hauptausschuss to the central office in Krakow, the case of 200 returnees is detailed. Travelling for three days and nights in locked freight cars, with wire mesh over the windows, the sick labourers lacked "any kind of care, and were without water and bread." Those who died were carried out wherever. "Many went unconscious due to exhaustion and hunger," while "a few stronger ones escaped through a window." All of the labourers were ill, "their feet swollen as a

\footnotetext{
${ }^{224}$ Markovna, Nina's Journey, 262.

${ }^{225}$ Decree, Reichsführer of the SS and Chief of the German Police, 20 February 1942, BArch R 3901/20481, fol.58-70.

${ }^{226}$ Makuch, "My Life," 3.
} 
result of hunger and dehydration, and could barely crawl around., ${ }^{227}$ The labourers explained to the UHA official that they had gone "singing to Germany," healthy and happy that they had been freed from the Soviets, and had mournfully returned due to starvation, not sure if they would survive the journey to Brest-Litovsk, let alone to their native Kharkiv. As previously mentioned, such stories of outright maltreatment caused voluntary recruitment numbers to plummet, and in an attempt to continue voluntary recruitment where possible, the regulations were altered in July $1943 .{ }^{228}$ Sauckel's office soon permitted the erection of special "sick assembly camps" in cities with large concentrations of Soviet workers. Workers would then only be permitted to travel home if deemed fit by medical personnel. ${ }^{229}$ Soviet Ukrainian recruits would be then sent with chronically ill and injured labourers to special intake camps in Brest-Litovsk and Minsk, from where they would be sent back to their hometowns. Polish Ukrainians, on the other hand, were simply sent in small groups back to the Generalgouvernement as soon as they were fit to travel. ${ }^{230}$

The recruitment process and journey to the Reich show contradictions in German policy vis-à-vis their Ukrainian and Eastern European workforce, and occupation policy in the East. Plummeting voluntary recruitment in the Generalgouvernement and Reichskommissariat Ukraine, combined with increased production needs in the Reich warranted a softer approach to recruitment. But actual conditions in the Reich,

\footnotetext{
${ }^{227}$ Letter to Ukrainischer Hauptauschuss Social Services Committee, 3 June 1942, Ukrainian Central Committee, p.379-80.

${ }^{228}$ Memo, Plenipotentiary General for Labour Deployment to Heads of Labour Offices, 3 July 1942, BArch R 3901/20481, fol.223-4.

${ }^{229}$ Memo, Plenipotentiary General for Labour Deployment to Heads of Labour Offices, 16 October 1942, BArch R 3901/20289, fol.85-6.

${ }^{230}$ Memo, Plenipotentiary General for Labour Deployment to Heads of Labour Offices, 3 July 1942, BArch R 3901/20481, fol.223-4.
} 
transmitted back to occupied Ukraine with sick and injured Ukrainians in return transports, would compound any attempts to move away from forced recruitment. In an attempt to make deployment in the Reich more attractive, and marking a shift in the war to a common struggle against the Bolshevik enemy, Nazi racial ideology was temporarily put aside, and regulations on the treatment of those deployed to the Reich were relaxed in May 1943. By this time, though, the damage had already been done. While Nazi officials in the Reich were praising the efforts of the workers from the East, surviving Ukrainians in the occupied territories had seen with their own eyes what came of their fellow nationals while deployed in the Reich, and only a shift to forced recruitment could then move Ukrainians out.

\section{II: Deployment}

After an increasingly more dramatic recruitment process, and a treacherous journey to the Reich in freight cars, fresh Ukrainian labourers from across the Occupied East arrived in the Reich to begin their service. How Ukrainians were deployed, what they earned, what their accommodations were like and how their stay in Germany was regulated is the focus of this next section, more generally summarised as the everyday living conditions of Ukrainian labourers in Nazi Germany. This section includes some novel findings on a training program for Polish Ukrainians, and shows further gaps in treatment of Polish- versus Soviet Ukrainians, attributed to malleable Nazi racialhistorical thinking that saw the two groups of Ukrainians placed on different levels.

From the transit camps, Ukrainians were deployed to their new workplaces throughout the Reich. The regulations concerning the deployment of Soviet citizens were 
much more severe versus those for Polish Ukrainians. The February 1942 instructions clearly stated that during their stay in the Reich, Soviet citizens were to be kept strictly apart from the German population. In factories, Soviet labourers could only be deployed in "enclosed columns" or Soviet-only work gangs. ${ }^{231}$ The same deployment was also ordered for Polish Ukrainians, a change with common practice since 1939 that saw them assigned according to industrial need and the workers' skill set. This slight change in the treatment of Polish Ukrainians, corresponding with a decrease in their labour rights to the level of Poles, could be explained by the triumphant Nazi mood after the rapid 1941 gains of Soviet territory. An increased sense of confidence in their goals in the East meant that Nazi officials in the Reich could closely adhere to their racial policy vis-à-vis foreign labourers, and even alter (albeit slightly) their stance toward the favoured PolishUkrainians. The new regulations allowed for individual deployment only in essential cases, with approval granted from the Reich Labour Administration. In agriculture, both Polish and Soviet Ukrainians were permitted to work individually. However Soviet Ukrainian men were to be housed in enclosed accommodations, and where possible, receive a common, impersonal treatment, with tasks assigned regardless of strengths and training. $^{232}$ The 1942 regulations similarly deprived Soviet Ukrainian men of individuality, while trying to avoid German-Soviet Ukrainian camaraderie. "It is therefore essential to set apart the German worker in his position," read the Reich Main Security Office instructions, "so that despite his cooperation, he gives the appearance of a supervisor and overseer, and a feeling of solidarity with these workers does not come into

${ }^{231}$ Decree, Reichsführer of the SS and Chief of the German Police, 20 February 1942, BArch R $3901 / 20481$, fol.58-70

${ }^{232}$ It is unclear how strict farmers and Nazi officials in the Reich countryside adhered to these orders. 
being." 233 In industry, the ideal deployment of Soviet Ukrainians was not merely a Soviet-only work gang, but a Soviet-only facility or "Russian Plant," in which Soviets would work under German overseers. ${ }^{234}$ To ensure this, "the responsible offices, Reich Labour Administration, German Labour Front [DAF, Deutsche Arbeitsfront] and Reich Nourishment Office [Reichsnährstand] will be in touch with the plant management to teach about the importance of and the various ways to increase the status of German people." 235 The April revisions implicitly acknowledged the difficulties of creating Soviet-only plants by permitting the use of smaller groups of Soviet labourers, while ruling that these smaller groups were not to be deployed amongst German or other foreign labourers. $^{236}$

In stipulating that Soviet Ukrainians throughout their stay in the Reich, and that Polish Ukrainians from January 1942 to January 1943, could only be deployed in enclosed groups, disregarding individual training and skills, one can note certain similarities with Himmler's "Thoughts on the Handling of the Foreign Peoples in the East," issued two years earlier on 28 May 1940. His memo, discussed in the first chapter, called for racially unreliable Eastern Europeans to be turned into a leaderless working people, dedicated to working en masse on labour-intensive building products in the

\footnotetext{
${ }^{233}$ Decree, Reichsführer of the SS and Chief of the German Police, 20 February 1942, BArch R 3901/20481, fol.58-70

${ }^{234}$ Memo, Plenipotentiary General for Labour Deployment to Heads of Labour Offices, 3 July 1942, BArch R 3901/20481, fol.223-4.

${ }^{235}$ The Deutsche Arbeitsfront was created in 1933 when Hitler outlawed independent trade unions, and therefore served as an amalgamated National Socialist trade union, looking after the interests of German workers while ensuring their loyalty to the state. The Reichsnährstand was founded in 1933, bringing together volunteer agricultural organisations, the Reich Land Federation and Agricultural chambers, and concerned itself with racial purity in agriculture, farming techniques (including use of foreign labourers), and commodity pricing.

${ }^{236}$ Decree, Reichsfiihrer of the SS and Chief of German Police, 9 April 1942, BArch NS 3/512, fol.282-3.
} 
Reich. ${ }^{237}$ The shift to individual deployment for Soviet Ukrainians took place beginning May 1943, in the wake of the post-Stalingrad foreign labour policy changes. The joint Reich Main Security Office and Reich Propaganda Ministry leaflet announced that "each foreign labourer, where possible, will be placed in a position that makes the best use of his education and previous responsibilities."238 This change was one of the only 1943 changes that actually came into effect, and made an influence on the lives of Soviet Ukrainians in the Reich.

A unique aspect of the deployment of Polish Ukrainians, and a novel discovery of this study, was the ability of some to choose between factory or farm deployment. As early as 1940, the German Labour Front, in cooperation with the German Steel and Metal Union, established a special training program into which Polish-Ukrainians were recruited. The program was an attempt to deploy more recruits from the overwhelmingly agricultural Generalgouvernement to industry, where out of a pre-war population of 750,000 ethnic Ukrainians, only 9,500 Polish-Ukrainians with skills training were counted, including 8,000 "intellectuals" and 1,500 craftpersons. ${ }^{239}$ In one case, a labourer from the Carpathian Mountains elected to work in a factory and was enlisted for the skills program. Over a period of six weeks, he received practical training as a locksmith, and was afterward deployed to a Berlin ammunitions factory. ${ }^{240}$ Skills training was not extended to Soviet Ukrainians until the post-Stalingrad changes of 1943 made individualised placements possible. Even then, training programs across the Reich varied,

\footnotetext{
237 "Denkschrift Himmlers über die Behandlung der Fremdvölkischen im Osten,” 28 May 1940, BArch NS $19 / 1737$.

${ }^{238}$ Circular letter from Party Chancellery, 5 May 1943, Doc 205PS IMT Vol.25, pp.298.

${ }^{239}$ Note, Kubijovyč, 13 December 1940, Ukrainian Central Committee, p.174-5; Letter, Kubijovyč to Deutsche Arbeitsfront Training Camp Department, 20 January 1941, Ukrainian Central Committee, p.184. ${ }^{240}$ Fedir Telka, Interview by Stephen C. Telka (April 112005 ).
} 
from quick one-day orientations on the basics of a machine, to fourteen-day training sessions for more complicated positions. ${ }^{241}$ The changing terms of deployment of Polish and Soviet Ukrainians in the Reich was therefore just one of many features of the forced labour experience that followed the course of war, causing racial concepts to be put aside for the greater goal of German victory.

\section{II: Pay \& Labour Rights}

Another field that marked by an ideological treatment of Ukrainian labourers, especially those from the Soviet Union, was the wage system, and the granting of labour rights. It was also an aspect of deployment that considerably differentiated Polish Ukrainians from Soviet Ukrainian Ostarbeiter. Polish Ukrainians, by and large, had the same pay and labour rights as Western workers, owing to their privileged status in the racial-political hierarchy. The only temporal exception was between February 1942 and January 1943, when their labour rights and taxation categories were temporarily dropped to the level of Poles. This was met with indignation from the Ukrainischer Hauptauschuss and its constituent Polish Ukrainians across the Reich. ${ }^{242}$ Figure two, taken from a wage document of the Ruhr District Committee for Rock Coal Mines, clearly shows the pay and taxation difference between the groups of Ukrainian labourers and their German foremen and colleagues. Although the table uses data from 1944, after

\footnotetext{
${ }^{241}$ Herbert, Hitler's Foreign Workers, 300-304.

${ }^{242}$ Spoerer, Zwangsarbeit unter dem Hakenkreuz, 156-7; "Behandlung der Ukrainer aus dem Generalgouvernment im Deutschen Reiche," June 1942, Ukrainian Central Committee, p.392-3; "Behandlung der Ukrainer aus dem Generalgouvernement im Reich," June 1942, Ukrainian Central Committee, p.394.
} 
a few small pay increases for Ostarbeiter had been implemented, it is still indicative of the wage differentials between the various groups of labourers.

Fig. 2: Ruhr Valley mine salary costs, per worker, per day (Feb. 1944, in Reichsmarks) ${ }^{243}$

\begin{tabular}{|r|c|c|c|c|c|c|}
\hline & Taxes & $\begin{array}{c}\text { Mandatory State } \\
\text { Deductions }\end{array}$ & $\begin{array}{c}\text { Severance } \\
\text { Pay }\end{array}$ & $\begin{array}{c}\text { Room \& } \\
\text { Board }\end{array}$ & $\begin{array}{c}\text { Net } \\
\text { Pay }\end{array}$ & $\begin{array}{c}\text { Labour Costs } \\
\text { (\% of German } \\
\text { labour cost })\end{array}$ \\
\hline Germans & 0.33 & 2.26 & 0.00 & 1.22 & 8.72 & $12.53(100)$ \\
\hline Western workers & 0.33 & 2.26 & 0.91 & 3.33 & 6.60 & $13.44(107)$ \\
\hline $\begin{array}{r}\text { Polish Ukrainians \& } \\
\text { Byelorussians }\end{array}$ & $\mathbf{0 . 3 3}$ & $\mathbf{1 . 9 0}$ & $\mathbf{0 . 9 1}$ & $\mathbf{3 . 3 3}$ & $\mathbf{6 . 6 0}$ & $\mathbf{1 3 . 0 7 ( 1 0 4 )}$ \\
\hline Poles & 1.37 & 1.86 & 0.61 & 3.33 & 5.36 & $12.53(100)$ \\
\hline Ostarbeiter & $\mathbf{1 . 3 8}$ & $\mathbf{0 . 4 8}$ & $\mathbf{0 . 0 0}$ & $\mathbf{3 . 3 0}$ & $\mathbf{1 . 8 6}$ & $\mathbf{7 . 0 2}(\mathbf{5 6})$ \\
\hline Western P.O.W.s & 1.26 & 0.31 & 0.00 & 3.32 & 1.68 & $6.57(52)$ \\
\hline Soviet P.O.W.s & 1.30 & 0.16 & 0.00 & 3.33 & 0.40 & $5.19(41)$ \\
\hline
\end{tabular}

The employment of Ostarbeiter was particularly cost-efficient, only $56 \%$ the cost of regular German labour in 1944 as shown in figure two. This had its roots in the substandard light in which Soviet Ukrainians were held. Further disadvantaging Soviet Ukrainians in the workplace was a lack of access to typical bonuses or sick pay, for example, that were granted to other German and higher-ranking foreign labourers, such as Polish Ukrainians. According to pay regulations for Ostarbeiter released 30 June 1942 by the Council of Ministers for Reich Defence (Ministerrats für die Reichsverteidigung) and the Commissioner for the Four-Year-Plan (Beauftragte für den Vierjahresplan), Soviet Ukrainians had no claim to regular surcharges and allowances for overtime, night shifts, and Sunday and holiday pay. Severance pay and apprentice pay were similarly not

${ }^{243}$ Spoerer, Zwangsarbeit unter dem Hakenkreuz, 185. 
paid out. ${ }^{244}$ Soviet Ukrainians were also responsible for paying for clothing, footwear, and transportation to and from their workplace, if the employer chose to charge for such services. In cases of sickness, sick pay was not given, and instead, Soviet Ukrainian and other Soviet labourers were not charged for room and board. They were not required to pay income nor municipal taxes, but industrial employers were forced to pay a special "Ostarbeiter tax," with agricultural employers paying half, an effort to ensure that Ostarbeiter labour did not become so inexpensive that they replaced German workers. Despite the dizzying amount of surcharges and deductions, Soviet Ukrainians did not receive pay stubs, as per the June 1942 regulations, which made it difficult to track charges and sort pay discrepancies. Holidays and trips home to see one's family were not granted to Soviet Ukrainians, as per the June 1942 regulations, which matched the March 1941 general ban on foreign labourer holidays and "family visits" 245 Ostarbeiter did, however, have the opportunity to save what was left of their weekly pay, which would then be sent back to a bank or family member in one's home region.

Even with the changes of February 1942 that brought Polish-Ukrainian workers' rights into line with those of ethnic Poles, Polish Ukrainians were still better treated than their fellow nationals from the Soviet Union. However, their drop in legal status in the workplace was still felt. From having the same working, income and tax rights as Germans from the start of their deployment in 1939, Polish-Ukrainians were relegated to the status of Poles on unknown grounds with an article in the 21 February 1942 edition of the Reich Labour Gazette (Reichsarbeitsblatt). ${ }^{246}$ Ukrainians from occupied Poland were

\footnotetext{
${ }^{244}$ Decree, Reich Defence Council, 30 June 1942, BArch NS 3/512, fol.284-276.

${ }^{245}$ Ibid; Regulations, General Administration, Dortmund, 23 February 1942, BArch R 3901/20288b, fol.810 .

${ }^{246}$ Spoerer, Zwangsarbeit unter dem Hakenkreuz, 156-7.
} 
no longer entitled to full vacation pay, but rather fifty percent, and only if the holiday fell on a Sunday. ${ }^{247}$ All previous entitlements to birthday, wedding, Christmas, and anniversary bonuses were removed. They were also required to pay the same fifteen percent "social services balancing surcharge" that ethnic Poles were already paying.

With the variety of deductions and taxes, what was the buying power of Ukrainians at the end of the day? One Polish Ukrainian remembers that he did indeed have money to spend, but "there was nothing to buy. Because everything was on ration cards. And we didn't have ration cards. That's only for German people... There was nothing in the market for foreigners or Ausländer to get something to buy." ${ }^{248}$ Soviet Ukrainian labourers similarly remember having spending money: "We also bought things, we had money. We got some money, a few marks. We bought ourselves something. One time we found a baker in the city who sold us something."249 Another labourer remembered that the Soviet boys from her factory, "would go and get a loaf from a German for five marks. They bring it into the camp, and take fifteen from us., 250 It can be concluded then, that although both Polish and Soviet Ukrainian labourers had some amount of spending money, due to general wartime shortages, and a lack of access to consumer goods, their Reichsmarks did not go very far. The money they did have, particularly in the case of Soviet Ukrainians, was spent to meet their basic needs, chiefly the purchasing of food stuffs, that were not only obtained on the open market, but also within the camps on the black market. The provision of pay and labour rights to ethnic Ukrainians thus shows the flexibility of Nazi racial policy in the face of war demands.

\footnotetext{
${ }^{247}$ Regulations, General Administration, Dortmund, 23 February 1942, BArch R 3901/20288b, fol.8-10.

${ }^{248}$ Fedir Telka, Interview by Stephen C. Telka (April 112005 ).

${ }^{249}$ Billstein, Working for the Enemy, 188.

${ }^{250}$ Ibid.
} 
The case of the usually favoured Polish Ukrainians makes this particularly clear, as their pay and benefits were decreased from February 1942 to January 1943, in an apparent act of Nazi confidence with their plans in the East. The issue of pay also highlights an everyday example of the malleability of Nazi racial policy, which resulted in Polish Ukrainians receiving much higher pay than their Soviet counterparts.

\section{II: Accommodation, Food \& Clothing}

Upon deployment, Ukrainian labourers in the Reich were quickly forced to become accustomed to their new surroundings and daily provisions. Despite various changes in policy and attempts to improve conditions, war exigencies meant that Ukrainians saw little change in their status and treatment. In terms of accommodation, the February 1942 regulations stipulated that both Polish and Soviet Ukrainians deployed to large factories and agricultural enterprises were to be housed apart from Germans in closed barracks. ${ }^{251}$ They were further split by Nazi regulations, between Polish- and Soviet Ukrainians. ${ }^{252}$ As one labourer recalls, each nation was housed separately, either together in one room or an entire barrack, with only occasional instances of mixing in cases of space shortages. ${ }^{253}$ Another labourer from Khmelnytsky, in Soviet Ukraine, described how the camps at the Fordwerk in Cologne were arranged, a setup typical for large industrial enterprises:

There was a barracks for men, a barracks for women, and another one for families. There were many barracks, because there were about 1,500 people there. There were about 350 to 400 to a barrack. These had three-

\footnotetext{
${ }^{251}$ Decree, Reichsführer of the SS and Chief of the German Police, 20 February 1942, BArch R 3901/20481, fol.58-70

${ }^{252}$ Decree \#4, Plenipotentiary General for Labour Deployment, 7 May 1942, BArch R 3901/20471, fol.516.

${ }^{253}$ Fedir Telka, Interview by Stephen C. Telka (April 112005 ).
} 
level platform beds, with an aisle along the middle, and there would be two or three ovens. In the winter these were heated with briquettes. There was nothing else. You could sit on the beds. There were about two stools per compartment [for six people]. There was nothing else, just the ovens. There was no washroom in the barracks, there was one on the camp grounds. The toilets were on the street. In the barracks there was no water. ${ }^{254}$

Furthermore, the initial regulations of February 1942 instructed that barracks housing Soviet Ukrainians were to be surrounded by barbed wire, to impress on both the German and labourer populations the danger of the Untermenschen. ${ }^{255}$ This echoed the treatment of Soviet prisoners of war, who were kept behind barbed-wire in open-air pens in the occupied East. ${ }^{256}$ "The first impression [was] very unfavourable," wrote one labourer from Soviet Ukraine, upon her arrival at her new workplace. "We were placed in poor wooden barracks fenced with barbed wire. We were ordered to get accustomed to it. ${ }^{, 257}$ In cases where barbed-wire enclosed barracks were not possible, such as on smaller family farms, the accommodation of Soviet men had to be lockable and kept easily under surveillance. The use of barbed wire was later banned by labour officials in April 1942. The removal of existing barbed-wire, however, was not at the top of plant managers' lists, as they were also dealing with persistent raw material shortages and increasingly devastating allied bombing raids, meaning that the barbed-wire enclosures sometimes remained in place well into 1943. The conditions in the camps, according to Sauckel's 7 May 1942 "Fourth Decree on the Recruitment, Care, Accommodation, Nourishment and Treatment of Foreign Labourers," were to be "exemplary, in regards to order, cleanliness

\footnotetext{
${ }^{254}$ Billstein, Working for the Enemy, 168.

${ }^{255}$ Decree, Reichsfiihrer of the SS and Chief of the German Police, 20 February 1942, BArch R 3901/20481, fol.58-70

${ }^{256}$ Spoerer, Zwangsarbeit unter dem Hakenkreuz, 71.

${ }^{257}$ Khelemendyk, Kolkohz Childhood and German Slavery, 107.
} 
and hygiene, and fitted out with all necessities," in an effort to highlight German civilisation, and prove "German supremacy, German mastery and German organisation."258 Agricultural workers were to be "accommodated using the same principles, but taking into account the special conditions of German agriculture." However, such "order, cleanliness and hygiene" was rarely reported in Ukrainian labour camps, particularly those for Soviet Ukrainians. The Central Office for Members of the Eastern Peoples reported in September 1942 that of nine kinds of complaints registered by Ostarbeiter, housing was the fourth most common. ${ }^{259}$ The 5 May 1943 "PostStalingrad" leaflet re-emphasised the ban on "prison-like barriers and barbed-wire," hinting towards its continued use, and a lack of sincere effort on the part of employers to move away from an ideological-oriented treatment. ${ }^{260}$

A general disregard for the conditions in camps for Soviet Ukrainians can be attributed to their low status as Untermenschen in the Nazi racial-political hierarchy. Attempts were made to monitor the condition of camps, including the barracks, food and heating, as evidenced with Sauckel's 15 July 1942 "Decree Number Nine," detailing a program in which Reich-wide Labour Offices would inspect all camps over the period of a month, to ensure standards were being met. ${ }^{261} \mathrm{~A}$ similar program was unveiled in January 1943 to specifically target Ostarbeiter camps and the general deployment of Soviet citizens. The end goal was to increase recruitment in the Occupied East, by ensuring a minimum standard of living, and avoiding further negative 'press' in the form

\footnotetext{
${ }^{258}$ Decree \#4, Plenipotentiary General for Labour Deployment, 7 May 1942, BArch R 3901/20471, fol.516

${ }^{259}$ Herbert, Hitler's Foreign Workers, 173.

${ }^{260}$ Circular letter from Party Chancellery, 5 May 1943, Doc 205PS IMT Vol.25, pp.298.

${ }^{261}$ Decree \#9, Plenipotentiary General for Labour Deployment, 15 July 1942, BArch R 3901/20288a, fol.53.
} 
of return transports and postcards sent home to relatives. ${ }^{262}$ Nazi efforts to ensure hygiene and order in the camps fit into German self-images of a wise and cultured nation spreading civilisation to the peoples of Europe. Their provision of housing in the Reich was to be an example of German modernity and civilisation, but was in reality often quite backward. The results of inspections of 1942 and 1943 are unfortunately unknown, with no archival documents found to follow up on the programs. Based on the consistent reports of unsanitary conditions in the camps by workers themselves, and the knowledge of further deteriorating internal supply lines within the Reich, it can be assumed that the programs did not effect a massive change in conditions in Polish and Soviet Ukrainian labour camps. The conditions in the countryside can be assumed to be even more variable, with accommodation dependant on the whims of individual families, but at least more stable than urban accommodation during the final eighteen months of the war. This urban-rural divide in the conditions of Ukrainian labourers that developed in the final months of the war hints toward the difficulty that Nazi officials faced in adhering to antiSlavic ideology as the frontlines gradually approached the Reich.

Even if attempts were made to improve the Ukrainian labourers' camps, improvements would have been quickly negated by the previously discussed bombing raids, which took attention away from the already neglected plight of workers' living conditions. In one account, a Polish Ukrainian deployed in Berlin recalled his barrack being damaged not by a direct bomb hit or flying shrapnel, but rather from the air pressure of bombs being released, which shifted the hastily built building off level. ${ }^{263}$ As a result, the labourer and his fellow inhabitants could not fully close the windows and ${ }^{262}$ Circular Letter, Plenipotentiary General for Labour Deployment to Reich Labour Trustees, 26 February 1943, BArch R 3901/21507,fol.222-6.

${ }^{263}$ Fedir Telka, Interview by Stephen C. Telka (April 11 2005). 
doors, thereby letting in cool weather, not to mention insects and rodents. The camp physician of the Krupp steel works in Essen described the deteriorating conditions in his company's camps:

With the onset of the heavy air-raids, conditions in the camps deteriorated progressively. The problem of housing, food and medical care became more acute than ever before. The workers were living in the ruins of their former barracks...After the air attacks of March 1943, we housed many Eastern workers directly in the Krupp plant buildings. A corner of the factory where they were working was boarded off. The workers on dayshift slept there at night, and those on night-shift slept there during the day, despite the constant noise reverberating through the factory halls. ${ }^{264}$

The same difficulties that sideswiped any possible attempts to improve the camp accommodations also affected the provisioning of food rations, particularly for Soviet Ukrainians in large industrial enterprises. Polish Ukrainians, while on the whole much better off than those from the Soviet Union, still experienced difficulties in obtaining food, especially so for urban industrial labourers in the final eighteen months of the war. According to the July 1942 "Ostarbeiter Leaflet," Soviet Ukrainians were to receive a predetermined food ration from the Reich Minister for Food and Agriculture, "based on the rates of the German civilian population" (my emphasis), but notably not equal. ${ }^{265}$ The rations were simply not adequate, and as one Ostarbeiter recalled, "We were always hungry. There was only soup in a little bowl. We called it balanda. It was water and cabbage." ${ }^{266}$ The inadequacy of food rations for industrially-deployed Ostarbeiter was a widely reported phenomenon throughout the first year of deployment. But despite the almost daily reports about the critical physical condition of the Ostarbeiter, the hungry

\footnotetext{
${ }^{264}$ Herbert, Hitler's Foreign Workers, 319.

${ }^{265}$ Leaflet for Plant Managers, Plenipotentiary General for Labour Deployment, 17 July 1942, BArch R 3901/20288a, fol.40-51 also BArch NS 3/512, fol.328-337.

${ }^{266}$ Billstein, Working for the Enemy, 178.
} 
public's criticism about the foreigners' allegedly excessive food rations continued. Consequently, with the 6 April 1942 reduction in rations for Germans, the Food Ministry announced eleven days later the already low rations for Ostarbeiter and prisoners-of-war would fall as well. ${ }^{267}$ Soviet Ukrainians across the Reich continued to hunger. The Mitteldeutsche Motorenwerke plant in Leipzig, for example, reported a daily absenteeism rate among Ostarbeiter of at least twelve percent, largely due to malnutrition. At a Nuremberg screw factory, the manager reported: "In the morning of March $12 \ldots$ all the Russian female labourers were sitting in the workrooms crying, complaining that they were in no condition to work due to the totally inadequate meal they had been given that morning." In Sterkrade, near Düsseldorf, at the Gutehoffnungshütte (GHH) iron and steel plant, an official wrote that the female Ostarbeiter were getting a daily ration of only three to four slices of dry bread plus some watery soup made from carrots and sauerkraut or turnips. "The GHH takes the view that because of such rations, the women are neither willing to work nor fit for the heavy physical labour. ${ }^{268}$ In a July 1942 weekly report by the Sicherheitspolizei, it was explained that due to physical weakness caused by malnourishment, "many workers simply cannot stand on their legs any more, let alone perform the smallest amount of work," a condition affecting twenty to twenty-five percent of the workforce. ${ }^{269}$ A consistently lower food ration for Soviet Ukrainian and other Soviet labourers had such negative impacts as illness, bad 'press' in the Occupied East through letters and postcards home to family, and a subsequent drop in voluntary recruitment. ${ }^{270}$ Moves to reduce the rations even further in April 1942 show the regime's

\footnotetext{
${ }^{267}$ Herbert, Hitler's Foreign Workers, 173.

${ }^{268} \mathrm{Ibid}, 172$.

${ }^{269}$ Meldungen aus dem Reich \#301, Reich Security Police, 26 July 1942, BArch R 58/173.

${ }^{270}$ Berkhoff, Harvest of Despair, 257-258.
} 
commitment to an ideological-based treatment of its workers from the East, even in the face of negative impacts on productivity and further recruitment. In an attempt to alleviate the Ostarbeiter food shortage, the Plenipotentiary General for Labour Deployment ordered the Labour personnel in the Occupied Soviet Union to encourage recruits to bring food supplies with them, such as flour, oil and sunflower seeds, which would be confiscated upon boarding the train to the Reich, and delivered to the camp kitchen. ${ }^{271}$ It is unlikely that many labourers actually brought such quantities of food supplies with them, as the food supply was already low in Occupied Poland and the Soviet Union, and most assumed, as was also the case with clothing below, that they would be well provided for, or at least better, in Germany.

Polish Ukrainians were generally better-off in terms of food. The regulations regarding their rations were worded similar to that for Soviet Ukrainians, stating that labourers were to receive "rations based on the normal rations of the German civilian population., ${ }^{, 272}$ Their post-war accounts of life in Germany rarely mention the issue of food, hinting toward a more consistent treatment. Furthermore, Polish and Soviet Ukrainians deployed in agriculture had a relatively secure food supply, and even if they did not receive the same amount as their employers, still had enough to sustain themselves, due to their proximity to food supplies.

In addition to problems in ensuring adequate housing and food, Nazi officials also experienced problems in the provisioning of clothing. According to the February 1942 "General Regulations" for Soviet Ukrainians and the May 1942 "Fourth Decree" for

\footnotetext{
${ }^{271}$ In-house Memo, Plenipotentiary General for Labour Deployment to War Administration Chief and Reichminister for the Occupied East, 9 July 1942, BArch R 3901/20481.

${ }^{272}$ Decree \#4, Plenipotentiary General for Labour Deployment, 7 May 1942, BArch R 3901/20471, fol.516
} 
Polish Ukrainians, it was stated that Ukrainian labourers should bring their own clothing and footwear, due to the "war circumstances" in the Reich. ${ }^{273}$ Nevertheless, the vast majority of Ukrainians who came to the Reich from both jurisdictions brought few personal belongings, assuming a short stay in the Reich, or that appropriate clothing would be provided. "We were not told that we were going to a factory," explained one labourer from Khmelnytskyi. "It was said, to the farmers, for a half-year, for the harvest." 274 Another remembered, "They had said, for six months. 'Then,' it was said, 'you will come back and others will be sent."' Consequently, each labourer in her transport had just one small bag. ${ }^{275}$ Nazi officials blamed the lack of adequate winter clothing on a number of other factors: the speed at which the labour recruitment program was initiated, the warm weather during major recruitment drives in the spring of 1942 , false information from native municipal officials, and enemy propaganda. ${ }^{276}$ Already in April, the Plenipotentiary General for Labour Deployment feared the effects that cold weather would have on increasingly important workers from the Occupied East. ${ }^{277}$ After an August 1942 appeal to recruitment officials instructing Ukrainian recruits to bring appropriate clothing with them, thousands of labourers still entered the Reich improperly provisioned. ${ }^{278}$ Already in October, incidents of illness due to inadequate clothing were being reported. From a foodstuff company in Frankfurt (Oder), the Sicherheitspolizei

\footnotetext{
${ }^{273}$ Decree, Reichsführer of the SS and Chief of the German Police, 20 February 1942, BArch R 3901/20481, fol.58-70; Decree \#4, Plenipotentiary General for Labour Deployment, 7 May 1942, BArch R 3901/20471, fol.5-16

${ }^{274}$ Billstein, Working for the Enemy, 168.

${ }^{275}$ Ibid, 174.

${ }^{276}$ Meldungen aus dem Reich, Reich Security Police, 15 June 1942, BArch R 58/172, fol.265-6; In-house Memo, Plenipotentiary General for Labour Deployment to War Administration Chief and Reichsminister for Occupied East, 15 August 1942, BArch R3901/20288a.

${ }_{277}$ Meldungen aus dem Reich, Reich Security Police, 15 June 1942, BArch R 58/172, fol.265-6.

${ }^{278}$ In-house Memo, Plenipotentiary General for Labour Deployment to War Administration Chief and Reichsminister for Occupied East, 15 August 1942, BArch R3901/20288a.
} 
reported that of the 115 female Ostarbeiter, within three days twenty-one were unable to work due to colds and abdominal illnesses. "The workers are poorly clothed, with each lacking even underwear, and the dresses that were brought are no longer usable." From a chemical factory in Ludwigshafen (possibly BASF), a plant official wrote:

The clothing that Ostarbeiter brought with them is in many cases inadequate and extremely poor. The Ostarbeiter usually possesses only one piece of clothing, that one can barely even consider clothing. Of 85 women, only 15 have one or two dresses, and the rest simply wear factorysupplied work clothing. At night, the work clothing is changed for their own clothing, which can only be defined as rags. In regards to underwear the situation is even worse. A shirt is a rarity, and it's a similar situation with shoes and socks. ${ }^{279}$

The provisioning of shoes was also a constant concern, with some reports from Kiel of workers walking barefoot or wrapping their feet with rags. ${ }^{280}$ Some attempts were made to solve the clothing and shoe situation. In an August 1942 notice, the DAF ordered camp directors to ensure that already distributed work clothing was handled carefully and properly cleaned, and that in particularly urgent cases, the directors could apply for work clothing from the local Economic Offices. ${ }^{281}$ Although the treatment of Ukrainian labourers was to be grounded in racial ideology, Nazi policy made provisions to ensure the basic needs of the labourers was met if wartime production was threatened. To further ensure that their labourers could work, the Plenipotentiary General for Labour Deployment also commissioned the manufacturing of wooden shoes, the cost of which would be deducted from labourer wages. ${ }^{282}$ Additionally, in September 1942 it released

\footnotetext{
${ }^{279}$ Meldungen aus dem Reich \#325, Reich Security Police, 12 October 1942, BArch R 58/176, fol. 107-12. ${ }^{280}$ Ibid.

${ }^{281}$ Memo, Thüringen Deutsche Arbeitsfront to Camp Leaders in Gau Thüringen, 17 August 1942, Barch NS $3 / 512$, fol.277.

${ }^{282}$ Memo, Plenipotentiary General for Labour Deployment to Leaders of Labour Offices, 28 September 1942, BArch R 3901/20289, fol.57; Memo, Plenipotentiary General for Labour Deployment to Reich Labour Trustees, 8 June 1943, BArch R 3901/21507, fol.38.
} 
details of a program in which family members in Reichskommissariat Ukraine could send their Ostarbeiter relatives winter clothing free-of-charge. ${ }^{283}$ Soviet Ukrainian and other Soviet labourers were given a pre-written letter to send to their families, explaining "winter is also coming soon in Germany, but as you know, I didn't bring my winter clothing," and detailing how the family member could receive up to 250 Rubles (25 Reich Marks) for sending clothing on a prescribed list, depending on the weight and the number of articles. It is unclear precisely how successful these initiatives were, with little mention of clothing within the collection of memoirs. One Soviet Ukrainian labourer, though, did recall finding "jackets and skirts" during her free time in a nearby village that Germans would put out for the workers. ${ }^{284}$ She further describes her ingenuity in recycling cloths from vehicle seats at the Fordwerk into material with which to make other clothing:

We made towels out of the oil cloths from the car seats. The seats were covered with an oil cloth. And this oil cloth we would attach to the assembly line...And once the line had turned around once...A nice material came out, it was orange coloured. And we would dye it black. Oil cloths in the cars. We secretly attached it on there, and then it came back out. We sewed something out of that. After all you have to cover yourself with something.

The clothing and footwear situation of Ukrainian labourers, especially those from the Soviet Union, shows how Nazi labour officials and employers deemed them an important but expendable resource. It was often through creativity and craftiness on the part of the labourer that sufficient clothing was acquired.

\footnotetext{
${ }^{283}$ Brochure for Factory Managers from Plenipotentiary General for Labour Deployment, 29 September 1942, BArch NS 3/512, fol.315; Memo, Plenipotentiary General for Labour Deployment to Labour Offices Heads, 15 October 1942, BArch R 3901/20289, fol.83.

${ }^{284}$ Billstein, Working for the Enemy, 178.
} 


\section{II: Surveillance \& Badges}

Also influencing the everyday existence of Ukrainian labourers in the Reich was a system of supervision, surveillance and identifying badges, which restricted their movements and freedoms. Further emphasising the treatment of Soviet Ukrainians as 'prisoners-of-work,' the February 1942 regulations stipulated that they were to be under constant supervision during their stay in the Reich. ${ }^{285}$ Guards would supervise the workers at their barracks, and special plant security forces, usually foremen, assistant foremen and German workers with Werkschutz (Plant security)-inscribed armbands would supervise them while on the job. In agriculture, the farm manager and German workers would take on such responsibilities. A ratio of 20-30 Soviet labourers to one security guard was declared, with the further instruction that security guards were not to work alone. Costs for employing security guards, as well as expenses related to their onsite accommodation, were to be borne by the enterprise. Polish Ukrainians were exempt from such constant supervision.

In a state where political and ethnic identity was ever-important, ethnic Ukrainians from both jurisdictions were obliged to carry identification with them around the clock. ${ }^{286}$ However, one's passport would not become the most prominent feature of one's identity. For Soviet Ukrainians, including those deployed as maids, the wearing of a badge became one of the most visible signs of his or her status as a worker from Eastern Europe. It also became a way by which Polish and Soviet Ukrainians were differentiated. From their entry into the Reich in 1939, and throughout the course of the war, Polish-

\footnotetext{
${ }^{285}$ Decree, Reichsführer of the SS and Chief of the German Police, 20 February 1942, BArch R 3901/20481, fol.58-70.

${ }^{286}$ Ibid.
} 
Ukrainians did not have to wear identifying badges, a recognition of their privileged position versus ethnic Polish and Soviet workers. "At a time when all Jews and inmates of Nazi concentration camps

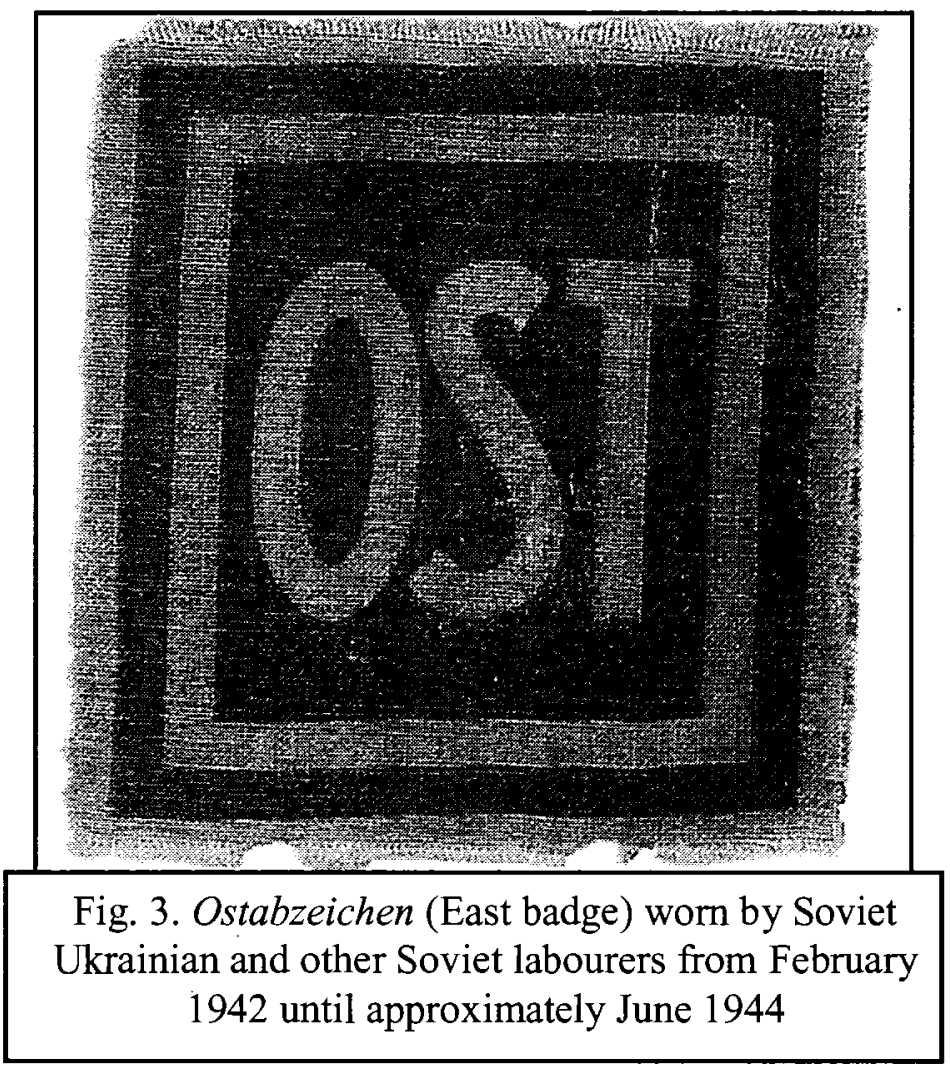
were likewise compelled to wear degrading insignia," explains Alexander Dallin, "it was bound to be considered, by Germans and Easterners alike, as an odious symbol of its wearer's inferior status. ${ }^{, 287}$

The Ostabzeichen, or Eastern badge, appeared first in a November 1941 SS directive, and was modelled after the system developed for Polish workers in March $1940 .{ }^{288}$ Soviet Ukrainians, along with fellow Byelorussians and Russians from the Union, were forced to wear the $70 \mathrm{~mm}$ by $77 \mathrm{~mm}$ badge on the right breast of each piece of clothing, bearing the white letters 'OST' on a blue background (Fig. 3.) ${ }^{289}$ Latvians, Estonians and Lithuanians, like Polish Ukrainians, were exempt from the badge obligation. Responsibility for the implementation of the badge regulation fell to the district police. Reich Main Security Office regulations made it clear that the badge was not to mark Ostarbeiter for

\footnotetext{
${ }^{287}$ Dallin, German Rule in Russia, 445.

${ }^{288}$ Herbert, Hitler's Foreign Workers, 70.

${ }^{289}$ Decree, Reichsfïhrer of the SS and Chief of the German Police, 20 February 1942, BArch R 3901/20481, fol.58-70.
} 
discrimination, but was rather simply, "a security-based necessity, due to the millions of deployed Ostarbeiter.,290

Most memoirs of Soviet Ukrainian labourers make mention of the badge and the restrictions that it placed on what they could and could not do with their free time. One labourer deployed to a Bavarian factory described how the factory owner "took out of one large envelope a bundle of small cloth badges, where on light background in dark blue ink were printed three letters - OST. 'There,"” the factory owner directed, “'Put it on the left side of your chest. Wear it always. What? You think it's degrading? Nonsense! All foreign workers wear badges. Poles wear a letter 'P.' You'll wear 'OST.", ${ }^{291}$ Another labourer describes herself and fellow labourers as being less disappointed with the idea behind the badges than the fact that Soviet Ukrainians were classified as Ostarbeiter, and referred to as Russians. "We disliked the idea that Germans considered us Russian," she recalled. "It insulted us. ${ }^{, 292}$ Upon handing in their foreign worker passes, and demanding to be classified as Ukrainians, their passes were returned, unchanged. "It turned out," she explained, "our plant police did not know how to define us for they thought Ukrainians were those who lived in Galytchyna [Galicia], the rest of us were 'Russ' for them." ${ }^{, 293}$ As a worker from Zaporizhzhia in eastern Ukraine, there was no recourse to shed her badge, as was the case with Polish Ukrainians mistakenly given 'P' badges, who could apply to the Ukrainische Vertrauenstelle in Berlin, demonstrated in the case in chapter two. The labourer bemoaned her situation which caused the effects of Stalin's totalitarian regime to continue to play an influence in their lives under another totalitarian regime. "The fact

\footnotetext{
${ }^{290}$ Circular, Reich SS Leader and Chief of the German Police, 18 July 1942, BArch R 58/1030, fol.179-86

${ }^{291}$ Markovna, Nina's Journey, 271-272.

${ }^{292}$ Khelemendyk, Kolkohz Childhood and German Slavery, 113.

${ }^{293}$ Ibid, 114.
} 
that we lived under Stalin's regime," she explained, "could not cancel out our nationality." She finally resigned herself to the situation and inability to do anything about it, stating, "We could do nothing about it, such was our fate." ${ }^{, 294}$ In addition to the typical labelling of Soviet Ukrainians as Ostarbeiter and the common initial labelling of Polish Ukrainians as Poles, it also appears that Polish Ukrainians were occasionally given the inferior Ostarbeiter label. Through a letter to the Ukrainischer Hauptausschuss, a group of Polish-Ukrainian ironworkers deployed to Trofaiach (modern central Austria) complained of their misidentification as Ostarbeiter, and their difficulties in living and working amongst a "fully foreign" group, with fewer liberties and privileges than other nationalities. ${ }^{295}$ The frequent confusion by Nazi officials in identifying ethnic Ukrainians shows the difficulties their status posed, and the problems caused by the flexibility of the Nazi racial-political hierarchy.

Discontent by Soviet Ukrainian labourers being labelled by the Nazi state as Ostarbeiter, which was interchangeable with the term 'Russian' for most Germans, was registered by various government bodies involved with Ostarbeiter, and the idea of developing badges for Ukrainians and the largest Soviet nationalities was discussed already in September $1942 .{ }^{296}$ However, labour officials quickly dismissed the idea, based primarily on the practical difficulties of implementing a new badge for Ukrainians, as hundreds of thousands of Ukrainians from the Generalgouvernement were already in the Reich and did not have to wear badges. Adding to the confusion of dealing with ethnic Ukrainians with two different sets of regulations, would be the added confusion of

\footnotetext{
${ }^{294}$ Khelemendyk, Kolkohz Childhood and German Slavery, 113.

${ }^{295}$ Kubijovyč , Note for the Records and letter from Polish Ukrainians in Iron Works camp in Trofaiach, Ostmark, 15 May 1942, Ukrainian Central Committee, p.414-7.

${ }^{296}$ Memo, Plenipotentiary General for Labour Deployment to Labour Office Heads, 25 September 1942, BArch R 3901/20290, fol.138.
} 
dealing with Russians and Byelorussians, from whom the Ukrainians would demand differential treatment. The issue again came up in March 1943 as labour officials attempted to announce measures that would increase productivity. While a distinct ' $U$ ' badge was not issued, Ostarbeiter were graded based on work performance, with poor performers wearing the 'OST' badge on his or her breast as the original regulations

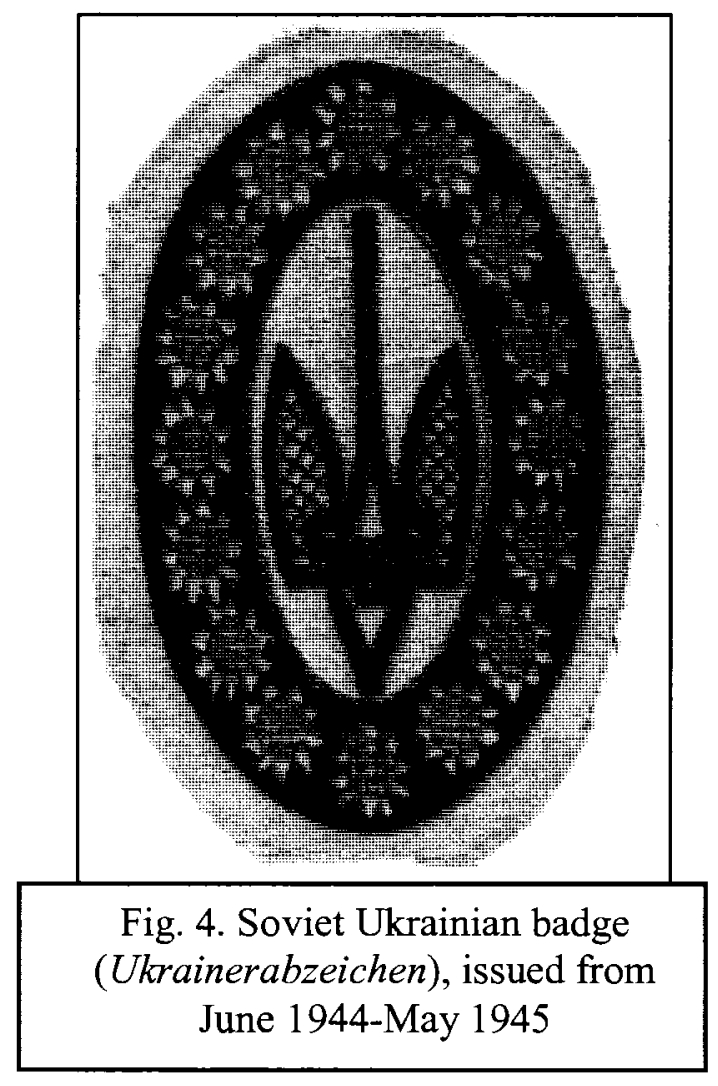
decreed, and high performers wearing the 'OST' badge on his or her left arm. ${ }^{297}$

The final change on the issue of badges came in June 1944, as the Wehrmacht was continually pushed back on both its western and eastern fronts, and the SS organised contingents of Soviet citizens to bolster the German fighting capacity. Recognising that "through their behaviour and performance, the Ostarbeiter have proven their willingness to cooperate in the battle against the Jewish-Bolshevik world danger," the Plenipotentiary General for Labour Deployment, together with the Reich Main Security Office announced a new set of badges that distinguished the main Soviet national groups. All badges would be surrounded by a border of sunflowers, with the Byelorussians' featuring a sheaf of wheat and a cog, the Russians' the cross of St.

\footnotetext{
${ }^{297}$ Herbert, Hitler's Foreign Workers, 290.
} 
Andrew, and the Ukrainians' the national trident (Fig. 4.) ${ }^{298}$ Rather than worn on the left breast, the new badges were to be worn on the upper-left arm, a practice that began with the 'productivity' badges of March 1943. Despite an energetic rally for Soviet workers in Berlin organised by the DAF and Plenipotentiary General for Labour Deployment to unveil the badges to the Ostarbeiter, the secondary literature, as well as the collection of Ukrainian labourer memoirs, is silent on whether the national Ostarbeiter badges were fully rolled out across the Reich. ${ }^{299}$ What is telling of the ideological undertones that served as the foundation of the new badges was the continued use of the badges themselves, as opposed to an outright elimination of the practice. Even with the 1943 post-Stalingrad changes to foreign labour policy, that officially removed most restrictions on Ostarbeiter, bringing them practically to the level of western labourers, the strict system of badges was kept in force up until the end of the war. ${ }^{300}$ The demands of the ideological bulwark of the party, the Reich Main Security Office, that Ostarbeiter and ethnic Polish workers in the Reich continue to be policed and monitored under strict rules, won the day.

In exploring how Ukrainians were deployed, what they were paid comparatively with other foreign groups, how they were housed, clothed and fed, and the badge regulations, one can identify a few trends. Owing to their close historical connection with the Austro-Hungarian Empire and Nazi weight placed on history, Polish Ukrainians, as can be seen, had a markedly better existence in the Reich. They were paid, housed and led a more liberal life than Soviet Ukrainians during their time in the Reich. Treated

\footnotetext{
${ }^{298}$ Memo and Decree, Plenipotentiary General for Labour Deployment to Gau Trustees for Labour, Labour Office heads, 25 August 1944, BArch R 3901/20467, fol. 145-151.

${ }^{299}$ Herbert, Hitler's Foreign Workers, 291.

${ }^{300}$ Circular letter from Party Chancellery, 5 May 1943, Doc 205PS IMT Vol.25, 298.
} 
almost as well as Western Europeans, Polish Ukrainians had such privileges as choosing a type of deployment and enrolling in a training program, a sort of treatment that Soviet Ukrainians did not see until after 1943. The racial and colonial ideology of the Nazi state can also be identified here as the foundation of Nazi treatment of Soviet labourers. However, as this section shows, pragmatism often held the day. The use of barbed wire and the provision of clothing, for example, show how the Nazis were forced to place less emphasis on ideology at times in order to ensure wartime production.

\section{III: Free time}

Although Ukrainians spent most of their waking hours on production lines and farm fields, they still had a modicum of free time. This next section deals with how Ukrainians spent their non-working hours, a topic mostly unexplored by current forced labour scholars, and touches on government-provided entertainment, the celebration of holidays, popular religion, and discusses briefly sexual relations. As with many aspects of Ukrainian labourers' life in Nazi Germany, free time was much more regimented for Ukrainians from the Soviet Union versus the Generalgouvernement. The initial regulations of February 1942 permitted labourers to leave the camp grounds only to go to work, meaning that free time was spent strictly at the camp. ${ }^{301}$ Labour officials loosened this slightly in April, and as a reward for good behaviour and productivity, Soviet Ukrainians were permitted to leave the camp, but only in closed groups with sufficient German supervision. Flight or any disturbances while on 'leave' would be punished by

${ }^{301}$ Decree, Reichsfïhrer of the SS and Chief of the German Police, 20 February 1942, BArch R 3901/20481, fol.58-70. 
the Reich Main Security Office with the suspension of the privilege. ${ }^{302}$ Underlining RSHA decisions on the matter was a widely-held fear amongst Nazi officials of the barbarian qualities of Soviet citizens. In an October 1942 memo to the Southwest Germany Labour Office, the Abwehr (Wehrmacht intelligence organisation) warned against giving Ostarbeiter unlimited freedom of movement, "as these primitive people would turn into unrestrained thieves. ${ }^{, 303}$ It was not until the 1943 post-Stalingrad shift in policy toward foreign labourers that the Plenipotentiary General for Labour Deployment granted Soviet Ukrainians full freedom of movement, an attempt to increase worker productivity by decreasing their racially-based discrimination vis-à-vis other workers. ${ }^{304}$ Polish Ukrainians, on the other hand, were free to leave the camp at their desire, except in cases of air bombings. One labourer from Soviet Ukraine reflected on the differential regulations guiding the lives of those from occupied Poland versus those from the East. "Ukrainian girls from West Ukraine had...a separate barrack, they were allowed to walk freely outside the camp, so they often went to the city" she wrote. "We, 'OST-girls," on the other hand, "were forbidden to go to the city, except on Sundays till 8 o'clock in the evening, but later we were also allowed to go out on Saturdays." She went on to comment that, "The rest of the girls went out every evening." 305

\section{III: Organised Activities, Radio, Newspapers and Film}

According to Fritz Sauckel's May 1942 "Fourth Decree," the planning for and execution of the intellectual and cultural treatment of foreign labourers was to take place

\footnotetext{
${ }^{302}$ Decree, Reichsfiihrer SS and Chief of the German Police, 9 April 1942, BArch NS 3/512, fol.282-3.

${ }^{303}$ Notes, Abwehrstelle Wehrkreis V to Plenipotentiary General for Labour Deployment, 6 October 1942, BArch R 3901/20270, fol.12.

${ }_{304}^{304}$ Circular letter from Party Chancellery, 5 May 1943, Doc 205PS IMT Vol.25, pp.298.

${ }^{305}$ Khelemendyk, Kolkohz Childhood and German Slavery, 115.
} 
in agriculture by the Reichsnährstand (Reich Nourishment Office), and everywhere else by the DAF. ${ }^{306}$ In the case of Soviet Ukrainian labourers deployed to industry, these tasks were delegated to the factory-appointed, but DAF- and State Police-approved Camp Directors. In a 1942 Directive to Ostarbeiter Camp Directors, the DAF emphasised the importance of organising free time activities for Ostarbeiter, who spent their nonworking hours "exclusively in the camp." 307 The Camp Director was therefore tasked, through cooperation with camp translators, senior labourers and Ostarbeiter order guards, to initiate free time activities, such as musical performances, folk dancing and handicrafts. The labourers themselves were to provide musical instruments, and labour officials in the Occupied East were to encourage new recruits to bring such equipment. Yet considering the often hasty nature of recruitment, and the shift to forced recruitment by the end of 1942 as explained in the second chapter, it is unlikely that many Ukrainian labourers, either Polish or Soviet, were able to bring such equipment. The DAF left the actual form of free time activities like concerts and handicraft sessions up to the Camp Director him/herself, due to the "various camp situations" found from factory to factory. ${ }^{308}$

Polish Ukrainians, unsurprisingly, had much more liberty in their free time activities. According to a July 1943 DAF memo that explicitly excluded ethnic Poles and Ostarbeiter, the DAF announced that "in all cities with a large amount of deployed

\footnotetext{
${ }^{306}$ Decree \#4, Plenipotentiary General for Labour Deployment, 7 May 1942, BArch R 3901/20471, fol.516

${ }^{307}$ Directive \#1 for Camp Leaders of Ostarbeiter Camps, German Labour Front, 1942, BArch NS 3/512, 268-274 (proceeded Decree \#4, Plenipotentiary General for Labour Deployment, 7 May 1942, BArch R 3901/20471, fol.5-16). ${ }^{308}$ Ibid.
} 
foreigners, a meeting place for the individual nations will be established." ${ }^{309}$ Where possible, such meeting houses for Polish Ukrainian were to be housed in rooms of existing pubs and taverns, where Ukrainians from the Generalgouvernement could hold "speeches, gatherings and events." The DAF instructed that each foreign labourer meeting house was to be marked with a bilingual external sign, featuring the DAF logo and "where permitted by the police, the coat of arms or the colours of the relevant nation," which could also be used to decorate the interior meeting rooms. It is unknown which symbol was used for the Ukrainians. Costs for the establishment of Polish Ukrainian and other foreign labourer meeting places were to be covered by the DAF, with maintenance and programming fees covered by the labourers through entrance fees and donations. The DAF also permitted foreign labourers to organise recreational groups, including sport, music, choral, theatre, games and language unions through the national meeting houses, and advertise their activities in factories, camps and through the press, in cooperation with the DAF.

The archival record, as well as the available collection of memoirs, is unfortunately silent on whether such meetings houses and recreational groups were indeed established by the DAF for Polish Ukrainians. It does appear that such recreational groups were established for Soviet Ukrainian and other Soviet labourers. A January 1943 document from the Office of the Plenipotentiary General for Labour Deployment to heads of the State Labour Offices, reports that "in several Ostarbeiter camps, choirs and music groups have been established." ${ }^{310}$ The document goes on to ask

\footnotetext{
${ }^{309}$ Decree, German Labour Front Office for Labour Deployment, 6 July 1943, BArch R 58/1030, fol.235237.

${ }^{310}$ Memo, Plenipotentiary General for Labour Deployment to Labour Office heads, 4 January 1943, BArch R 3901/20482, fol. 243.
} 
labour officials to further promote the creation of such groups, in order to spread the reach of already travelling music troupes, including a bandura band and a Cossack orchestra. $^{311}$

In addition to recreational groups, travelling musical troupes and Polish Ukrainian meeting houses, labour officials also produced Ukrainian- and Russian-language newspapers and radio programs for Ukrainian labourers, and translated German-made films into Russian. Newspapers for Soviet Ukrainians, firstly, were produced through cooperation between the DAF, the Reich Propaganda Ministry and the Reich Ministry for the Occupied East (Reichsministerium für die besetzten Ostgebiete.) Three newspapers appeared for those from the Soviet Union: Ukrainian-speakers could read the "Ukrainez" (the Ukrainian), Russian-speakers "Trud" (Work), and Byelorussian-speakers "Bielarusky Rebotnyk" (Byelorussian worker). ${ }^{312}$ And in a new finding, preened from the documents of the Ukrainischer Hauptauschuss, Polish Ukrainians deployed in the Reich had access to their own daily and weekly newspapers from Galicia. ${ }^{313}$ It is unclear, however, who produced them, and how widespread they were. Newspapers generally seem to have been quite popular, particularly for Ostarbeiter, according to December 1942 reports from the Reich Main Security Office:

The inhabitants of a local camp, housing female workers, ceremonially pounce upon several copies of each edition. Each woman wants to have the paper first, until finally one of them reads the contents of the newspaper out loud to the others, who listen devoutly. The newspaper finds satisfactory acceptance, and during free time that same evening, is

\footnotetext{
${ }^{311}$ The bandura is a Ukrainian plucked-string folk instrument.

${ }^{312}$ Directive \#1 for Camp Leaders of Ostarbeiter Camps, German Labour Front, 1942, BArch NS 3/512, 268-274.

${ }^{313}$ Kubijovyč , Note for the Records and letter from Polish Ukrainians in Iron Works camp in Trofaiach, Ostmark, 15 May 1942, Ukrainian Central Committee, p.414-7.
} 
passed around from hand to hand. The newspaper generates a visible level of outer satisfaction amongst the workers. ${ }^{314}$

Another company reported:

As long as the newspapers are delivered promptly to the factory, one can observe a particularly beneficial impact on the part of Ostarbeiter. One usually ascertains this is linked to the workers snatching up the newest edition. They are delighted to finally hear news from their homeland. Commonly, the pages are read to the others by someone who can read, before they are passed from hand to hand to look at the pictures. ${ }^{315}$

While newspapers were evidently well-accepted, the wide-spread popularity of radio programs is assumed to be lower. According to the $1942 \mathrm{DAF}$ directives for camp directors, the Reich Ministry for the Occupied East produced a one to two hour news program for Ostarbeiter each afternoon in Russian or Ukrainian, which could be played in the barracks. Since Ostarbeiter themselves could not own radios, they relied on camp directors who did not always have the best interests of the camp inhabitants in mind, to provide them. Furthermore, if Soviet Ukrainians had day-shifts, they were prevented from hearing the news, further reducing the audience of such programs. Less clear is the widespread viewing of films by Ukrainian labourers. The 1942 DAF directives for Ostarbeiter camp directors stated simply that the DAF had "no objections to the viewing of films for Ostarbeiter in camps and factories. ${ }^{316}$ Further regulations from the DAF permitted camp directors during December 1942 to rent a limited selection of films with Russian subtitles. Viewings were to take place in the Ostarbeiter camps or the union rooms at larger factories, and as a last resort, at private screenings in cinemas, "without upholstered seats," highlighting the racial undertones that guided Nazi labour policy

\footnotetext{
${ }^{314}$ Reich Security Police, Meldungen von dem Reich \#346, 29 December 1942, BArch R 58/178, fol. 145147.

${ }^{315}$ Ibid.

${ }^{316}$ Directive \#1 for Camp Leaders of Ostarbeiter Camps, German Labour Front, 1942, BArch NS 3/512, 268-274.
} 
toward Ostarbeiter. ${ }^{317}$ Altogether, it is evident that the Reich Nutrition Office and DAF, together with camp directors in urban centres, made an attempt to provide ways to keep labourers occupied during their nonworking hours, with some efforts like newspapers receiving more resonance among Ukrainians than other efforts. The very existence of such features as Nazi-produced newspapers and musical troupes appears to contradict earlier Nazi ideology, which portrayed Soviet Ukrainian and other Soviet labourers as cultureless, barbaric Untermenschen. In providing such leisure activities, labour officials hoped to "generate a visible level of outer satisfaction" amongst workers, which they hoped would then turn into productivity and higher output.

\section{III: Popular Religion \& Holidays}

Another way in which labour officials hoped to keep workers content and productive, but at the same time not stray too far from Nazi ideology, was through the provision of religion. The 18 July 1942 Reich Main Security Office guidelines for the handling of Ostarbeiter stated that "pastoral care for Ostarbeiter is not desired.", 18 Ostarbeiter were forbidden from leaving camp grounds to attend church services, including under German supervision. ${ }^{319}$ Priests, whether German or Ukrainian, were on the other hand forbidden by the State Police to enter the camp grounds for any reason. Church services were nonetheless permitted for Soviet Ukrainians, as long as they were

\footnotetext{
${ }^{317}$ Memo, Plenipotentiary General for Labour Deployment to Labour Office heads, 4 January 1943, BArch R 3901/20482, fol. 243.

${ }^{318}$ Circular, Reichsfïhrer of the SS and Chief of the German Police, 18 July 1942, BArch R 58/1030, fol.180-6.

${ }^{319}$ Leaflet for Plant Managers, Plenipotentiary General for Labour Deployment, 17 July 1942, BArch R 3901/20288a, fol.40-51 also BArch NS 3/512, fol.328-337.
} 
led by lay priests, and did not cause disruptions in the camp. ${ }^{320}$ A July 1943 Reichssicherheitspolizei report paints a clear picture of the religiosity of Soviet citizens deployed to the Reich, and their views on the Nazi regulations regarding religion. The State Police reported that amongst the population of Ostarbeiter, Ukrainians were the most religious. "For them," the report reads, "participation in church activities is a need of the heart. ${ }^{, 321}$ In a camp in Cottbus (100km south of Berlin), factory officials reported:

In the "New Holland" camp, only women and families are housed. Here, the desire for pastoral care is great. The longing to visit a church is expressed particularly on Sundays and holidays. In many cases, one can see the mood. If for whatever reason a strain or stress enters their spirit bad news from the home front, and such - they search out the little space where the icons stand, and pray. That is the only comfort that they have. With men in the same camp, religious activities are not as important as forth, but they still hold a great veneration for the icons.

Officials in Esslingen (near Stuttgart) reported similar experiences with Ostarbeiter religiosity:

The realisation of orthodox Easter shows clearly that the ceremonies of Orthodox Church survive through a great proportion of Ostarbeiter, mostly women from Ukrainian villages, then male Ostarbeiter of agricultural background, and above all those over forty-eight years old. On Easter morning, in a camp near Esslingen, a group of Ostarbeiter held a procession from barrack to barrack, singing liturgical hymns to start the Easter festivities with the barrack residents. In the evening, they repeated the ceremony. The numerical participation and inner sympathy was huge. It could generally be seen that the Ostarbeiter preparations for Easter were done with great devotion and love, and the festival itself was celebrated with inner participation. ${ }^{322}$

The persistent religiosity of women, especially those from Soviet Ukraine, shows the survival of religion amongst some sectors of the Soviet population. While young Ostarbeiter and those from Soviet Russia scoffed at the idea of participating in religious

\footnotetext{
${ }^{320}$ Circular, Reichsführer of the SS and Chief of the German Police, 18 July 1942, BArch R 58/1030, fol.180-6.

${ }^{321}$ Security Service, SD-Berichte zu Inlandsfragen, 15 July 1943, BArch R 58/186, fol.85-89.

${ }^{322}$ Ibid.
} 
activities, with such remarks as "No priest, more food!," ethnic Ukrainian men and women embraced the religious freedom that their residence in the Reich entailed. ${ }^{323}$ Still religious freedom for Soviet Ukrainians was not complete. Ostarbeiter were particularly irked by the Reich Main Security Office ban on priests of any denomination serving their pastoral needs. State police officials in the region of Anhalt (near Magdeburg) reported on the difficulties with lay priests:

At a religious event, the designated lay priest was very unsure, and did not know how to properly fulfil his duties. He eventually pulled out a number of crumpled notes from his jacket pocket, and tried to read them. Because he continued to show great insecurity while reading them, a large portion of the Ostarbeiter left the room. A few expressed that they would not participate again in such events. In another situation, the mere emergence of the allotted lay priest caused unruliness in the assembled crowd. The unruliness became particularly great when the lay priest explained that he was not a priest, but rather an assistant. He wanted to read his sermon, but could not even start. After some difficulties, and some long persuasion, he determinedly began to read. The festive disposition of the crowd, which at the start was described as good, was by this time completely gone. One can describe this mass as a one of the many in a long row of failures. ${ }^{324}$

Recognising the positive impact that religion had on the mood of Ostarbeiter and their workplace performance, the considerable discontent that the ban on priests was having, and taking into account the post-Stalingrad change in approach to Ostarbeiter deployment, the Reich Main Security Office permitted the pastoral care of Ostarbeiter in June 1944. The new regulations called for German officials fleeing Red Army advances in the East to bring Orthodox priests with them to the Reich to serve the pastoral needs of the Ukrainian, Russian and Byelorussian labourers. ${ }^{325}$ The presence of Orthodox priests was to be a low-key affair, with entrance to camps only by invitation, simple masses held outside the camp ("as not to disturb the running of the factory,") and no advertising of

\footnotetext{
${ }^{323}$ Security Service, SD-Berichte zu Inlandsfragen, 15 July 1943, BArch R 58/186, fol.85-89.

324 Ibid.

${ }^{325}$ Memo, Reich Security Police to Police Departments, 1 June 1944, BArch R 58/1030, fol. 285-289.
} 
services. ${ }^{326}$ It is unclear how widely Orthodox priests were spread across Ostarbeiter camps in the final year of the war. The change in policy toward the pastoral care of Soviet Ukrainian and other Soviet labourers is another example of the late-war shifts in policy regulating Ostarbeiter that attempted to increase their productivity by improving their treatment.

The archival record, as well as the collection of memoirs, is unfortunately silent on the pastoral care of Ukrainians from the Generalgouvernement. The Plenipotentiary General for Labour Deployment's May 1942 "Fourth Decree," as well as the updated post-Stalingrad "General Conditions" from May 1943 do not mention religious freedoms available for foreign labourers. ${ }^{327}$ Lacking specific regulations in an otherwise tightly controlled state, and with the knowledge that in most other regards, Polish Ukrainians were better treated than their Soviet counterparts, it can be assumed Ukrainians from Occupied Poland had a much higher level of religious freedom during their residence in the Reich.

Nazi labour officials aimed to use not only regular religious care to increase productivity, they also intended to use religious holidays like Christmas, New Year and Easter to showcase the positive treatment of Ostarbeiter in the Reich, with the further goal of increasing recruitment results in the Occupied East. During the holiday season of 1942-1943, in addition to celebrating German Christmas, the Plenipotentiary General for Labour Deployment also declared that Orthodox Christmas and New Year (7-8 and 14 January respectively) would also be celebrated. Ostarbeiter were to have an afternoon

\footnotetext{
${ }^{326}$ Only Orthodox priests were to be recruited, to the exclusion of such groups as Catholics and Evangelicals, due to "security concerns."

${ }^{327}$ Decree \#4, Plenipotentiary General for Labour Deployment, 7 May 1942, BArch R 3901/20471, fol.516; Circular letter from Party Chancellery, 5 May 1943, Doc 205PS IMT Vol.25, pp.298.
} 
break from work, during which special events could take place. Lost working hours and output were to be made up by increased working hours surrounding the holidays. ${ }^{328}$ Furthermore, each Soviet Ukrainian and Soviet labourer was to receive a pound of sunflower seeds from the Plenipotentiary General to celebrate the Orthodox holidays, in addition to 'extra' rations that were to be saved from reduced rations in the preceding days. ${ }^{329}$

Polish Ukrainians, on the other hand, were evidently only permitted to celebrate Christmas on 24-5 December, although many were members of the Uniate (Greek Catholic) Church and followed the Julian (Orthodox) calendar. The Ukrainischer Hauptausschuss, however, ensured that they had a Christmas feast above and beyond their daily rations. Just as the governments and representative bodies of the Czechs, Slovaks and French did, in December 1943 the UHA arranged with the German Labour Front and the Reich Nutrition Office to provide Polish Ukrainians in the Reich, particularly those deployed to industry, with a Christmas dinner. ${ }^{330}$ The UHA ordered flour, fat, meat, honey, marmalade and sugar, and had it distributed to camps housing Ukrainians from the Generalgouvernement. Although the Christmas dinner is not mentioned in memoirs by Polish Ukrainians, the food was indeed delivered, evidenced by

\footnotetext{
${ }^{328}$ Memo, Plenipotentiary General for Labour Deployment to Labour Offices, 30 December 1942, BArch R 3901/20482; Reich Security Police, Meldungen aus dem Reich \#353, 25 January 1943, BArch R 58/179, 221-224.

${ }^{329}$ Memo, Plenipotentiary General for Labour Deployment to Labour Offices, 5 January 1943, BArch R $3901 / 20482$, fol.245.

${ }^{330}$ Kubijovyč to Generalgouvernement Department of Nutrition and Agriculture, 13 December 1943, Ukrainian Central Committee, p.643; O.Kotyk-Stepanowytsch, Hauptauschuss Representative in Berlin to German Labour Front, 21 January 1944, Ukrainian Central Committee, p.670-671.
} 
an invoice from the government of the Generalgouvernment to the UHA for one hundred thousand Reichsmark. ${ }^{331}$

The situation of popular religion amongst ethnic Ukrainians, along with the celebration of holidays, once again shows how Nazi labour officials carefully balanced racial principles and war aims with labour demands and greater wartime exigencies. The initial restrictions on Orthodox priests providing pastoral care to Ukrainian and other Soviet labourers reflected the strict strain of racism that justified the initial German advance into the Soviet Union. As industry and government figures increasingly recognised the importance of foreign workers from Eastern Europe to the German war effort, restrictions were loosened, with the hope of increasing production and gaining support for the 'struggle against Bolshevism.' The decision of the Plenipotentiary General to grant time off for Orthodox holidays followed the same logic; a pure propagandist measure to increase workplace production and meet wartime needs.

\section{III: Sexual Relations}

Sexual relations, between Ukrainians, Germans and other foreign labourers, both voluntary and involuntary, is an aspect of the Ukrainian labour experience demanding indepth research that is unfortunately beyond the scope of this study. A few words on the topic will therefore have to suffice. In accordance with Reich Main Security Office regulations, sexual relations between Ukrainians and Germans were strictly prohibited, and regardless of the territory of origin, were punishable by public hanging, just as was

\footnotetext{
${ }^{331}$ Generalgouvernement Interior Administration to Hauptauschuss Representative in Berlin, 4 February 1944, Ukrainian Central Committee, p.683.
} 
the case with ethnic Poles. ${ }^{332}$ However, the rules were frequently broken, and camp commanders and guards often viewed female Ostarbeiter as fair game, using threats and rape or presents of money and privileges to obtain what they wanted. Nazi authorities further encouraged the commoditisation of sex amongst foreign workers by establishing 60 bordellos with 600 prostitutes by 1943 , with another 50 under construction. ${ }^{333}$ Illegal prostitution, according to Herbert, was far more widespread, and could be found in almost every larger camp. ${ }^{334}$ Sexual violence, evident in many accounts of the Holocaust, is also assumed to have taken place during the Ukrainian forced labour experience. ${ }^{335}$ According to Doris L. Bergen, "[i]t seems reasonable to conclude that rape and sexual slavery by Germans were more common among women from those groups targeted for enslavement - above all, Slavs - that from those slated for destruction: Jews, Gypsies, and people deemed handicapped. ${ }^{336}$ It is unknown, however, how many Ukrainians were employed as prostitutes, legally let alone illegally, and the extent of their sexual victimisation. Despite the differing conditions found in concentration camps, certain similarities with prostitution in forced labour camps can be drawn. As Christa Schikorra writes in her study on prostitution in the Ravensbrück concentration camp, although some women volunteered to work as prostitutes while others were 'recruited' involuntarily, the

\footnotetext{
${ }^{332}$ Decree, Reichsfiihrer of the SS and Chief of the German Police, 20 February 1942, BArch R 3901/20481, fol.58-70; BA-R58-1030 8 March 1940

${ }^{333}$ Herbert, Hitler's Foreign Workers, 219-220.

${ }^{334}$ Ibid.

${ }^{335}$ Doris L. Bergen, "Sexual Violence in the Holocaust: Unique and Typical?" in Lessons and Legacies Volume VII: The Holocaust in International Perspective, edited by Dagmar Herzog, (Evanston: Northwestern University Press, 2006), 179-200.

${ }^{336}$ Doris L. Bergen, "Sex, Blood, and Vulnerability: Women Outsiders in German-Occupied Europe," in Social Outsiders in Nazi Germany, edited by Robert Gellately and Nathan Stoltzfus, (Princeton: Princeton University Press, 2001), 277.
} 
work was undoubtedly merely another form of forced labour. ${ }^{337}$ Given what we know of the forced nature of recruitment that brought ethnic Ukrainians to the Reich for other types of employment, it can be assumed that those girls and women deployed to brothels did not have a great influence on their deployment and their treatment therein.

\section{IV: Case Study - Eastern Maids}

One unique program that brought thousands of Ukrainians to the Reich was the "Deployment of female labourers from the Old Soviet Realm," which has otherwise received little attention in current scholarship, and therefore will receive special attention here. ${ }^{338}$ The program, which brought Soviet Ukrainians as well as Polish citizens to work as maids in German households, was an effort to impress on the population the advantages of winning in the East. It was also an attempt to relieve the burden of women, who had to deal with food shortages, their closest male family members fighting afar, and the prospect of compulsory service in industry. In another sign of the flexibility of race in Nazi Germany, Hitler summarily dismissed party objections to having female Untermenschen working in the homes of the Reich, stating that "we would have to revise our school knowledge about the great migration of peoples" because there were so many blond, blue-eyed Ukrainians who "might be the peasant descendants of Germanic tribes which had never migrated." ${ }^{\text {339 }}$ The program contradicted Nazi racial ideology, failing to solve any pressing need in the war economy or the domestic kitchens of the Reich. As

\footnotetext{
${ }^{337}$ Christa Schikorra, "Forced Prostitution in the Nazi Concentration Camps," in Lessons and Legacies Volume VII: The Holocaust in International Perspective, edited by Dagmar Herzog, (Evanston: Northwestern University Press, 2006), 170.

${ }^{338}$ Decree, Reichsführer SS and Chief of German Police, 10 September 1942, BArch R 58/1030, fol.194196.

${ }^{339}$ Memo on meeting at Plenipotentiary General for Labour Deployment, 3 September 1942, Doc. 25PS IMT vol. 25 , p. 84 .
} 
Herbert explains, the program "was part of a political principle that, as far as foreigners were concerned, often appears more like a chain of contradictions and mistaken decisions than a calculated political strategy." ${ }^{340}$ Soviet Ukrainian and other Soviet females, seen as a subservient, subaltern population, were slotted for use by the "master race" to tend the sacred heart of the German nation, the home. The program also seemed to operate in contradiction to the efforts of Reichsdeutsche women sent to the Occupied East to Germanise the resident Volksdeutsche population, in the face of so-called "Polish management" (Polnische Wirtschaft, a byword for disorder and inefficiency that could be used to describe a home, business or farm. $)^{341}$ Through the deployment of Soviet and Polish maids, the sacred role of maintaining some of the defining characteristics of German civilisation, including cleanliness, order and hygiene in the German home, was left in the hands of people traditionally regarded as dirty and disorderly. ${ }^{342}$ As the fortunes of the German war changed, so did the tone of Nazi ideology. Although the program had high recruitment goals, by the middle of August 1944 only 77,000 foreign maids had been assigned to German households, comprised equally of Soviet citizens and Poles. ${ }^{343}$ The precise number of ethnic Ukrainians is unfortunately unknown.

One of the first stages in the experience of Soviet women and girls deployed to the Reich as maids was a racial screening, in the form of a "rough selection" to screen out

\footnotetext{
${ }^{340}$ Herbert, Hitler's Foreign Workers, 188.

${ }^{341}$ For more on the role of Reichsdeutsche women in Germanising the Occupied East, see Nancy R. Reagin, Sweeping the German Nation: Domesticity and National Identity in Germany, 1870-1945, (Cambridge: Cambridge University Press, 2007) and Elizabeth Harvey, Women and the Nazi East: Agents and Witnesses of Germanization, (New Haven: Yale University Press, 2003).

${ }^{342}$ The prime example of German efforts to juxtapose German civilisation, order and cleanliness with the situation in Eastern Europe is the Nazi comparison with the Soviet Union in the propagandistic publication Der Untermensch, as explored in chapter one of this study. Poles were seen in the same light in popular and scientific literature before and during the war, as evidenced in Reagin, Sweeping the German Nation, 184191.

${ }^{343}$ Spoerer, Zwangsarbeit unter dem Hakenkreuz, 12.0
} 
"foreign-raced, primitively eastern and east Baltic-natured people," carried out by representatives of the SS and Labour Administration. The regulations stated that it was not the goal necessarily to seek out "Germanisable" women, but rather females who looked German. ${ }^{344}$ This is an interesting example of the flexibility of the Nazi racialpolitical hierarchy. With the onset of Operation Barbarossa and the invasion of the Soviet Union, all Soviet citizens were labelled Untermenschen, with no exceptions to the rule. However, just over a year later, Nazi officials permitted 'subhumans' to enter the sacred heart of the Reich, the homestead, where they worked in kitchens and nurseries, prepared the sustaining meals of the German nation, and cared for the future leaders of German-led Europe. As long as the women did not have "Asiatic" features, and generally resembled Germans, they were deemed racially acceptable for deployment as maids.

Female Soviet Ukrainians designated for use as maids were then transported in special train cars, and on the transport list noted as "Unobjectionably appropriate for use in households," indicating their racial-political reliability. ${ }^{345}$ They were welcomed to the Reich with another racial screening by representatives of the SS and Labour Administration. Those deemed to appear too "un-German" were deployed to industry and agriculture. It was also possible for officials to put particularly "German-looking" recruits targeted for industry and agriculture through the racial screening process, and deploy them as maids. ${ }^{346}$ There were not only special conditions to become a maid; there were also special conditions to be able to employ one. Employing a Soviet maid in 1940s Germany was an upper-middle-class status symbol at an affordable price, at a time when

\footnotetext{
344 Decree, Reichsfiihrer SS and Chief of German Police, 10 September 1942, BArch R 58/1030, fol.194196.

${ }^{345}$ Ibid.

${ }^{346}$ Ibid.
} 
most families were focused on being prudent due to food and commodity rationing. The September 1942 legislation restricted the deployment of Soviet females as maids only to "politically reliable families," who would agree to follow the regulations. The selection of families was delegated on the local level to National Socialist public authorities, with "child-rich" and so-called "model families" specifically targeted. A maid would have been a significant perk for such large families, at a time when most household duties were still not mechanised. Soviet Byelorussians, Russians and Ukrainians deployed as maids in cities were to be strictly engaged in household duties, staying away from the operation of homerun businesses. Those on family farms were only to be involved with the operation of farms as much as "normal" farm maids. In cases where German maids were already employed, precautions were to be taken to avoid any feelings of solidarity.

Soviet maids were also to be housed apart from Germans, and would not be deployed to families lacking such facilities, based on Reich Main Security Office fears of miscegenation. ${ }^{347}$ Their food situation was significantly better than their fellow Soviet labourers in industry and agriculture, as those deployed as maids received the same rations as the German civilian population. ${ }^{348}$ In terms of free time, Soviet housemaids had even less than typical Soviet labourers; officially the regulations stated that they had "no claim to free time," and that they were only to leave the house to carry out housekeeping duties. It was possible, though, for maids to receive three hours each week without responsibilities, during which they would be permitted to leave the household. Such outings were to end by sunset, or 8:00pm at the latest, and visiting bars, light shows, and theatres for Germans or other foreign labourers was forbidden. Attending church services

\footnotetext{
${ }^{347}$ Decree, Reichsfïhrer SS and Chief of German Police, 10 September 1942, BArch R 58/1030, fol.194196. ${ }^{348}$ Ibid.
} 
was similarly forbidden. The regulations also stated that the DAF would make possible arrangements for free time activities. ${ }^{349}$ The deployment of 77,000 foreign maids to German households serves as a microcosm for the greater foreign labour program, which brought 2.4 million Ukrainians to Germany. The foundational racist ideology of the National Socialists that initially resulted in Soviet citizens enclosed behind barbed wire in factory camps was gradually relaxed as the course of the war changed. Seeking a way to give everyday meaning in the Reich to the 1941-2 territorial gains in the East, Nazi labour officials brought thousands of Soviet and Polish females to work in German households. The dirty, disorderly and unhygienic characteristics formerly applied to Poles and Soviet citizens were seemingly forgotten, as newly 'recruited' maids busied themselves with cleaning and tending the kitchens and nurseries of the Reich.

Altogether this chapter paints a comprehensive picture of the everyday experience of Ukrainian labourers in Nazi Germany, while highlighting various instances when Nazi ideology was put aside in order to sustain the war effort. Race was not the only determinant in shaping the fate and experience of Ukrainians. Contradictions and an often liberal application of Nazi racial policy existed from the recruitment and shipment to the Reich, and throughout the Ukrainian labourer everyday. While Nazi officials in the Reich were praising the efforts of the workers from the East in an effort to boost worker productivity and recruitment, the Wehrmacht and local officials in the Occupied East resorted to ever harsher techniques to meet their quotas. Terms of deployment were changed as production needs expanded, allowing plant managers to deploy Ukrainians

\footnotetext{
${ }^{349}$ Decree, Reichsführer SS and Chief of German Police, 10 September 1942, BArch R 58/1030, fol.194-
} 196. 
individually rather than in groups. Labour officials soon banned the use of barbed wire from Ostarbeiter camps, due to its negative impact on worker morale and further recruitment. And the Plenipotentiary General for Labour Deployment soon developed programs to address the substandard housing and clothing situations of Eastern labourers (albeit with unknown results.) The provision of free time activities by labour officials further shows a clear balancing act between Nazi racial principles and greater wartime exigencies. Lastly, the case-study on the deployment of Soviet females as maids serves as a microcosm of the entire foreign labour program, with a significant softening of racial policy. Additionally, Polish Ukrainians in the Reich were consistently given an upper hand over Soviet Ukrainians, showing the practical outcome of the malleable Nazi racial hierarchy. Wartime pragmatism, as argued in this chapter, was often more important than Nazi ideology. 


\section{Conclusion}

The Ukrainian war experience was one of change, turmoil and destruction. Trapped between two ideologically opposed regimes, ethnic Ukrainians were forced to navigate a confusing sea of allegiances and concerns, balancing loyalties to family, nation and political system, in a bid for mere survival. Those who stayed faced occupation, upheaval and war firsthand. Those sent to Germany found only a modicum of comfort in their exile. Ukrainians from both the Generalgouvernement and Reichskommissariat Ukraine were 'recruited' from the Occupied East to the Reich by often violent means, transported inhumanely in cattle cars, compelled to carry out physically demanding work under harsh conditions for little pay and soon forced to live in a Germany under attack. The way in which Ukrainians were treated in the face of the changing course of war has been the focus of this paper. As the war progressed, and Nazi officials realised the importance of 'their' Eastern workforce, the harsh racist ideology that motivated the German spread eastward was put on hold. The Ukrainian case, as this paper has argued, speaks to the flexibility and limits of Nazi racial policy, given the realities of waging war and sustaining the war effort. Race was not the final determinant in shaping the fate and experience of Ukrainian labourers. My goal has been to demonstrate the unique situation of Ukrainians, and attempt to untangle the confusing regulations and statuses of an ethnic group who found their treatment in the Reich not based on ethnicity like most other groups, but rather on their citizenship, largely Polish and Soviet.

The first chapter provided a comprehensive overview of the background of foreign labourers in Germany and the ideological underpinnings of the labour program. As seen, the German experience during the First World War is of importance in 
understanding the program that unfolded during the Second. Labour shortages during the Second World War were nothing new to Germany. Nor was the use of Eastern European labourers without precedent. Underlying the treatment and philosophy towards the millions of Ukrainians and other Eastern Europeans deployed by occupation officials to the Reich was hostile Nazi ideology, similarly rooted in the German Great War experience. Through changes in German anthropology, and the rise of the National Socialist party, Eastern Europe was increasingly viewed by Germans as the future of their nation. Despite Nazi plans to subjugate, assimilate and eliminate the sea of nations to its East, war exigencies simply 'got in the way.' Nazi wartime production officials saw the pragmatism in bringing Ukrainian and other Eastern Europeans to the Reich en masse as labourers, rather than Germanic-looking individuals for assimilation. While ideological restrictions were relaxed with the deployment of two million ethnic Ukrainians to the German heartland, they were not fully forgotten. The Nazi ideology that drove plans to colonise the vast steppes of the East still informed decisions on how Ukrainian and other foreign labourers were treated, and certainly had an impact on the day-to-day lives of labourers. The division of Polish and Soviet Ukrainians, furthermore, along lines of citizenship proved to be an interesting example of the malleability of the racial Nazi hierarchy, which had consequences on the treatment of Soviet Ukrainians over their favoured Polish Ukrainian fellow nationals.

In discussing the different phases of Ukrainian deployment in chapter two, a few trends were identified. The first Ukrainian labourers to enter the Reich from both Occupied Poland and the Occupied Soviet Union were not civilians, but rather prisonersof-war, who in both cases were released directly before or directly after entering the 
Reich, owing to their ethnicity vis-à-vis the larger, more stigmatised groups Poles and Soviet Russians. Nazi labour officials used their initial experiences with the Poles as a blueprint when deciding how to regulate the deployment of Soviet citizens. Both ethnic Poles and Soviet citizens experienced blatant racism and general subjugation to other national groups in Germany. Polish Ukrainians, however, were considered distinct in the eyes of labour officials and Nazi ideologues, due to their historical ties with the AustroHungarian Empire, and were always placed higher in the racial-political hierarchy. Furthermore, in both jurisdictions, reports from Ukrainians already in Germany combined with violent and terrorising recruitment techniques caused voluntary recruitment levels to evaporate, necessitating even more extreme tactics and further complicating the administration of the occupied areas. While National Socialist racial-political ideology was gradually applied more liberally to Ukrainian and other foreign labourers as Germany's war fortunes changed, Ukrainians on the ground saw few changes. The postStalingrad policy shift of 1943 to the official Nazi approach to the war had little impact, both in the Occupied East where recruitment techniques became only more brutal, and within the boundaries of the Reich, which was being increasingly weakened by allied bombing raids. The racist and colonial Nazi ideology that was used by the upper echelons of the German state to justify the war was relaxed, but not fully forgotten. Rather than a fundamental re-writing of anti-Slavic racial policy, Nazi officials simply changed the tone, and the way in which it was applied.

The third chapter, lastly, provided insight into the everyday experience of Ukrainian labourers in Nazi Germany, while highlighting various instances when Nazi ideology was put aside in order to sustain the war effort. As was argued, contradictions 
and an often liberal application of Nazi racial policy existed from the recruitment and shipment to the Reich, and throughout the Ukrainian labourer everyday. While Nazi officials in the Reich were praising the efforts of the workers from the East in an effort to boost productivity and recruitment, the Wehrmacht and local officials in the Occupied East resorted to ever harsher techniques to meet their quotas. Terms of deployment were changed as production needs expanded, allowing plant managers to deploy Ukrainians individually rather than in groups. Labour officials ordered barbed wire-surrounded camps for Soviet Ukrainians, and a few months later banned its use. The provision of free time activities by labour officials showed further a clear balancing act between Nazi racial principles and greater wartime exigencies. The final case study on the deployment of Soviet females as maids served as a microcosm of the entire foreign labour program, which saw a significant softening of racial policy. Wartime pragmatism was frequently more important than Nazi ideology.

While this study has shed some much-needed light and insight into the deployment of ethnic Ukrainians to the Reich, it is by no means exhaustive, and calls for further research into a few areas. The parallels with the Ukrainian forced labour experience and that of Eastern European Jewry as part of the Holocaust deserves particular attention. The precise influence and interaction of the Ukrainian Vertrauensstelle, Ukrainischer Hauptausschuss, forced labourers and the Nazi regime also warrants consideration. The topic of sexual relations amongst Ukrainians, foreign labourers, and Germans currently suffers from a paucity of research. The Soviet maid program could benefit from a study of its own. And lastly, the experience of Ukrainians deployed to agriculture requires a more thorough, in-depth investigation. 
The collapse of the Soviet Union and the end of the Civil War has radically transformed the geopolitical landscape of Eastern Europe. The Ukrainian nation is for the first time truly independent, and as part of its state-building process, Ukrainians are reexamining their history, and attempting to fill in previous blanks. This study, therefore, permits a broader understanding of this period in the history of Ukrainians, and can be considered a contribution to both Ukrainian and Second World War studies. It further hints toward the difficulties the newly formed post-war Ukrainian state faced in bringing together at least two different groups of Ukrainians, and challenges the assumptions of the unity based solely on ethnicity. 


\section{Bibliography}

\section{$\underline{\text { Archival Sources }}$}

Bundesarchiv, Berlin

NS 3 SS-Wirtschafts-Verwaltungshauptamt

NS 19 Persönlicher Stab Reichsführer-SS

NS 43 Außenpolitisches Amt der NSDAP

R 58 Reichssichertheitshauptamt

R 3901 Reichsarbeitsministerium

\section{Interviews - Oral Histories}

Anonymous. 2005. Inteviewed by Stephen C. Telka. Tape recording. April 11. Private Residence, Kington.

Telka, Fedir. 2005. Interview by Stephen C. Telka. Tape recording. April 11. On telephone from private residence, Kingston.

\section{Primary Sources}

Basansky, Bill. Escape from Terror. Plainfield: Logos International, 1976.

Boelcke, Willi A., ed. Wollt Ihr den totalen Krieg? Die geheimen Goebbels-Konferenzen 1939-1943. Stuttgart: Deutsche Verlags-Anstalt, 1967.

George, Amy and Al Janssen. Goodbye is Not Forever. Eugene: Harvest House Publishers, 1994.

Hitler, Adolf. Hitler's Table Talk, 1941-1944. Translated by Norman Cameron and R.H. Stevens, edited by Hugh Tervor-Roper. Oxford: Oxford University Press, 1988.

---- Mein Kampf, Hurst and Blackett Ltd, 1939, http://gutenberg.net.au/ebooks02/0200601.txt . Also available in print form.

Internationaler Militärgerichtshof Nürnberg. Der Prozeß gegen die Hauptkriegsverbrecher vor dem Internationalen Militärgerichtshof Nürnberg 14. November 1945 - 1. Oktober 1946. Official text, German edn., 42 volumes, Nürnberg, 1947.

Khelemendik-Kokot, Antonina. Kolkohz Childhood and German Slavery. Ukraine: n.p., 1993. 
Luczak, Czeslaw, ed. Polozenie polskich robotników przymusowych w Rzeszy, 19391945, Documenta Occupationis, vol. IX. Poznan: Instytut Zachodni, 1975.

Makuch, Elias. "My Life Story" (unpublished personal memoir, held by Stephen C. Telka, 1997).

Markovna, Nina. Nina's Journey. Washington: Regnery Gateway, 1989

Rachner. "Arbeitseinsatz und Arbeitsverwaltung in den besetzten Gebieten." Reichsarbeitsblatt 19/2 (1939): 370-2.

Reichsführer-SS, Nationalsozialistische Deutsche Arbeiter-Partei. Der Untermensch. Berlin: Vertrieb Nordland Verlag, 1942.

Rüter-Ehlermann, Adelheid L. and C.F. Rüter. Justiz und NS-Verbrechen. Sammlung deutscher Strafurteile wegen nationalsozialistischer Tötungsverbrechen 1945-1966, ed., 22 vols, Amsterdam: Amsterdam University Press, 1968-.

Siegmund, Vera Tkatschenko. My Ukrainian Footprints. United States: s.n., c.1994.

Veryha, Wasyl. The Correspondence of the Ukrainian Central Committee in Cracow and Lviv with the German Authorities, 1939-1944. Edmonton: Canadian Institute of Ukrainian Studies Press, 2000.

\section{$\underline{\text { Secondary Sources }}$}

Alakus, Baris, Katharina Kniefacz and Robert Vorberg, eds. Sex-Zwangsarbeit in nationalsozialistchen Konzentrationslagern. Wien: Mandelbaum Verlag, 2006.

Allen, Michael Thad. The Business of Genocide: The SS, Slave Labor, and the Concentration Camps. Chapel Hill: University of North Carolina Press, 2002.

Bergen, Doris L. "Sex, Blood, and Vulnerability: Women Outsiders in German-Occupied Europe." In Social Outsiders in Nazi Germany, edited by Robert Gellately and Nathan Stoltzfus, 273-293. Princeton: Princeton University Press, 2001.

---_-“Sexual Violence in the Holocaust: Unique and Typical?" In Lessons and Legacies Volume VII: The Holocaust in International Perspective, edited by Dagmar Herzog, 179-200. Evanston: Northwestern University Press, 2006.

Berkhoff, Karel C. Harvest of Despair: Life and Death in Ukraine under Nazi Rule. Cambridge: Belknap Press of Harvard University Press, 2004.

Betz, Frank-Uwe. Zwangsarbeit in Schwetzingen: Lager für ausländische Arbeiter zur Zeit des NS-Regimes. Pfaffenweiler: Centaurus-Verlagsgesellschaft, 1998. 
Billstein, Reinhold, Karola Fings, et. al. Working for the Enemy: Ford, General Motors and Forced Labor in Germany during the Second World War. New York: Berghahn Books, 2000.

Brandes, Karin, et.al. Zwangsarbeit in Marburg 1939-1945: Geschichte, Entschädigung, Begegnung. Marburg: Rathaus-Verlag der Stadt Marburg, 2005.

Brown, Kate. A Biography of No Place: From Ethnic Borderland to Soviet Heartland. Cambridge: Harvard University Press, 2004.

Chodakiewicz, Marek Jan. Between Nazis and Soviets: Occupation Politics in Poland, 1939-1947. Lanham: Lexington Books, 2004.

Ĉistova, Bella E. And Kirill V. Cistov, eds. “Fliege, mein Briefchen, von Westen nach Osten... “: Studien zur Volksliedforschung \#18. Bern: Peter Lang, 1998.

Dallin, Alexander. German Rule in Russia, 1941-1945: A Study of Occupation Policies. London: MacMillan \& Co, Ltd., 1957.

Dyczok, Marta. The Grand Alliance and Ukrainian Refugees. Houndmills: Macmillan Press Ltd, 2000.

Evans, Andrew D. "Anthropology at War: Racial Studies of POWs during World War I." In Worldly Provincialism: German Anthropology in the Age of the Empire, edited by H. Glenn Penny and Matti Bunzi, 198-229. Ann Arbor: University of Michigan Press, 2003.

Feichtlbauer, Hubert. Zwangsarbeit in Österreich. Wien: Braintrust, 2005.

Freund, Florian, Bertrand Perz and Mark Spoerer. Zwangsarbeiter und Zwangsarbeiterinnen auf dem Gebiet der Republik Österreich 1939-1945. Wien: Oldenbourg Verlag, 2004.

Frings, Bernhard and Peter Sieve. Zwangsarbeiter im Bistum Münster: Kirchliches Handeln im Spannungsfeld von Arbeitseinsatz, Seelsorge und Krankenpflege. Münster: dialogverlag, 2003.

Gewald, Jan-Bart. "Kolonisierung, Völkermord und Wiederkehr. Die Herero von Namibia 1890-1923." In Völkermord in Deutsch-Südwestafrika. Der Kolonialkrieg (1904-1908) in Namibia und seine Folgen, edited by Jürgen Zimmerer und Joachim Zeller, 105-120. Berlin: Links, 2003.

Giurescu, Dinu C. Romania in the Second World War. Boulder: East European Monographs, 2000. 
Grinchenko, Gelinada. Nevygadane: Usni istorï octarbayteriv / Avtor-uporyad., red., vstup. St. X: Vydavnychiy Dim 'Rayder,' 2004.

---- 2007. The shaping of remembrance: individual, group and collective patterns of memory of former Ukrainian Ostarbeiters. Beyond Camps and Forced Labour. Current International Research on Survivors of Nazi Persecution. Proceedings of the International Conference London, 11-13 January 2006, eds Johannes-Dieter Steinert and Inge Weber-Newth. Osnabrück: Secolo Verlag, 2007 (Forthcoming).

---- 2008. Oral Histories of Former Ukrainian 'Ostarbeiter': Preliminary Results of Analysis. Toiling for the Reich: Life Stories of Former Forced and Slave Laborers under Nazi Rule, 1939-1945, 2008 (Forthcoming).

Hagen Hennies, Jörg. Entschädigung für NS-Zwangsarbeit vor und unter der Geltung des Stiftungsgesetzes vom 2.8.2000. Saarbrücken: Nomos, 2006.

Haller, Christian. Der „Ausländereinsatz “ in Pforzheim während des Zweiten Weltkrieges. Heidelberg: verlag regionalkultur, 2004.

Harvey, Elizabeth. Women and the Nazi East: Agents and Witnesses of Germanization. New Haven: Yale University Press, 2003.

Held, Steffen and Thomas Fickenwirth. Fremd- und Zwangsarbeit im Raum Leipzig 1939-1945: Archivalisches Spezialinventar und historische Einblicke. Leipzig: Leipziger Universitätsverlag, 2001.

Herbert, Ulrich. Fremdarbeiter: Politik und Praxis des "Ausländer-Einsatzes" in der Kriegswirtschaft des Dritten Reiches. Berlin: Verlag J.H.W. Dietz Nach GmbH, 1985.

---- Hitler's Foreign Workers: Enforced Foreign Labor in Germany under the Third Reich. Cambridge: Cambridge University Press, 1997.

Hillmann, Barbara, Volrad Kluge and Erdwig Kramer. Lw. 2/XI - Muna Lübberstedt Zwangsarbeit für den Krieg. Bremen: Edition Temmen, 1996.

Hopmann, Barbara, et. al. Zwangsarbeit bei Daimler-Benz. Stuttgart: Franz Steiner Verlag, 1994.

Homze, Edward L. Foreign Labor in Nazi Germany. Princeton, New Jersey: Princeton University Press, 1967.

IG Farben: Von Anilin bis Zwangsarbeit. Stuttgart: Schmetterling Verlag, 1995.

Jacobmeyer, Wolfgang. Vom Zwangsarbeiter zum Heimatlosen Ausländer. Göttingen: Vandenhoeck \& Ruprecht, 1985. 
Kamenetsky, Ihor. "German Colonization Plans in Ukraine during World Wars I and II." In German-Ukrainian Relations in Historical Perspective, edited by Hans-Joachim Torke and John-Paul Himka, 95-109. Edmonton: Canadian Institute of Ukrainian Studies Press, 1994.

Keller, Michael. "Das mit den Russenweibern ist erledigt" Rüstungsproduktion, Zwangsarbeit, Massenmord und Bewältigung der Vergangenhei in Hirzenhain 1943-1991. Friedberg (Hessen): Verlag der Bindernagelschen Buchhandlung, 1991.

Littmann, Friederike. Ausländische Zwangsarbeiter in der Hamburger Kriegswirtschaft 1939-1945. München: Dölling und Galitz Verlag GmbH, 2006.

Liulevicius, Vejas Gabriel. War Land on the Eastern Front: Culture, National Identity, and German Occupation in World War I. Cambridge: Cambridge UP, 2001.

Losurdo, Domenico. "Toward a Critique of the Category of Totalitarianism." Historical Materialism, 12.2 (April 2004): 25-55.

Lower, Wendy. "A New Ordering of Space and Race: Nazi Colonial Dreams in Zhytomyr, Ukraine, 1941-1944." German Studies Review 25-2 (May 2002): 227254.

----Nazi Empire-Building and the Holocaust in Ukraine. Chapel Hill: University of North Carolina Press, 2005.

Magosci, Paul Robert. Ukraine: An Illustrated History. Toronto: University of Toronto Press, 2007.

Mason, Timothy W. Sozialpolitik im Dritten Reich. Arbeiterklasse und Volksgemeinschaft. Westdeutscher Verlag: Opladen, 1977.

McMahon, Maureen. "Manpower Aspects of the German Economic Exploitation of the Ukraine: 1941-1944.” M.A. diss., University of Wisconsin, 1966.

Mendel, Annekatrein. Zwangsarbeit im Kinderzimmer: „Ostarbeiterinnen “ in deutschen Familien von 1939 bis 1945. Frankfurt am Main: dipa-Verlag, 1994.

Meyer, Winfried and Klaus Neitmann, eds. Zwangsarbeit während der NS-Zeit in Berlin und Brandenburg: Formen, Funktion und Rezeption. Potsdam: Verlag für BerlinBrandenburg, 2001.

Moczarski, Norbert, Bernhard Post and Katrin Weiss, eds. Zwangsarbeit in Thüringen 1940-1945. Erfurt: Landeszentrale für politische Bildung Thüringen, 2002. 
Mommsen, Hans and Manfred Grieger. Das Volkswagenwerk und seine Arbeiter im Dritten Reich. Düsseldorf: ECON Verlag, 1996.

Moore, Bob and Kent Fedorowich, eds. Prisoners of war and their captors in World War II. Oxford: Berg, 1996.

Nichtweiss, Johannes. Die ausländischen Saisonarbeiter in der Landwirtschaft der östlichen und mittleren Gebiete des Deutschen Reiches von 1890-1914. Berlin (GDR): Rütten und Loening, 1959.

Polyan, P. Zhertvia dvukh diktatur: Zhizn', tprud, unizheniia i smert' sovetskikh voennoplennkh I ostarbayterov na chukhbne i na rodine (Victims of Two Dictatorships: Life, Labour, Humiliation and Death of Soviet Captives and Ostarbeiter at Home and Abroad). Moscow, 2002.

Proctor, Robert. "From Anthropologie to Rassenkunde in the German Anthropological Tradition." In History of Anthropology vol. 5 - Bones, Bodies and Behavior: Essays on Biological Anthropology, edited by George W. Stocking, Jr., 138-179. Madison: University of Wisconsin Press, 1988.

Reagin, Nancy R. Sweeping the German Nation: Domesticity and National Identity in Germany, 1870-1945. Cambridge: Cambridge University Press, 2007.

Reitlinger, Gerald. The House Built on Sand: The Conflicts of German Policy in Russia 1939-1945. London: Widenfeld and Nicolson, 1960.

Riss durchs Leben: Erinnerungen ukrainischer Zwangsarbeiterinnen im Rheinland (Katalog zur Ausstellung). Köln: Landschaftsverband Rheinland, 2007.

Ritter, Gerhard. Staatskunst und Kriegshandwerk vol.3, Munich: R. Oldenbourg, 1966.

Ruggenthaler, Peter. „Ein Geschenk für den Führer“: Sowjetische Zwangsarbeiter in Kärnten in der Steiermark 1942-1945. Graz: Selbstverlag des Vereins zur Förderung der Forschung von Folgen nach Konflikten und Kriegen, 2002.

Scharf, Eginhard. „Man machte mit uns, was man wollte“ Ausländische Zwangsarbeiter in Ludwigshafen am Rhein 1939-1945. Heidelberg: verlag regionalkultur, 2004.

Schikorra, Christa. "Forced Prostitution in the Nazi Concentration Camps." In Lessons and Legacies Volume VII: The Holocaust in International Perspective, ed. Dagmar Herzog, 169-178. Evanston: Northwestern University Press, 2006.

Schinkel, Eckhard, ed. Totaler Arbeitseinsatz für die Kriegswirtschaft: Zwangsarbeit in er Deutschen Binnenschifffahrt 1940-1945. Essen: Klartext Verlag, 2005. 
Schminck-Gustavus, Christoph U. Hungern für Hiter: Errinerungen polnischer Zwangsarbeiter im Deutschen Reich 1940-1945. Reinbeck bei Hamburg: Rowohlt Taschenbuch Verlag GmbH, 1984.

Schulte, Theo J. The German Army and Nazi Policies in Occupied Russia. Oxford: Berg Publishers, 1989.

Schumann, Wolfgang, Gerhart Hass, Karl Drechsler. Deutschland im zweiten Weltkrieg. 5 vols., Köln: Pahl-Rugenstein, 1974-84.

Schwarze, Gisela, ed. Die Sprache der Opfer: Briefzeugnisse aus Russland und der Ukraine zur Zwangsarbeit als Quelle der Geschichtsschreibung. Essen: Klartext Verlag, 2005.

-----Kinder, die nicht zählten: Ostarbeiterinnen und ihre Kinder im Zweiten Weltkrieg. Essen: Klartext Verlag, 1997.

Spitzmüller, Bernd. „....aber das Leben war unvorstellbar schwer... “: Die Geschichte der Zwangsarbeiter und Zwangsarbeiterinnen in Freiburg während des Zweiten Weltkrieges. Frieburg im Breisgau: Archiv der Stadt Freiburg im Breisgau, 2004.

Spoerer, Mark. Zwangsarbeit Unter dem Hakenkreuz: Ausländische Zivilarbeiter, Kriegsgefangene und Häftlinge im Deutschen Reich und im besetzten Europa 19391945. Stuttgart: Deutsche Verlags-Anstalt, 2001.

Streit, Christian. Keine Kameraden. Die Wehrmacht und die sowjetischen Kriegsgefangenen 1941-1945. Stuttgart: Deutsche Verlags-Anstalt, 1978.

Subtelny, Orest. Ukraine: A History. Toronto: University of Toronto Press, 1988.

Urban, Thomas. Zwangsarbeit im Tagebau: Der Einsatz von Kriegsgefangenen und ausländischen Zivilarbeitern im mitteldeutschen Braunkohlenbergbau 1939 bis 1945. Essen: Klartext Verlag, 2006.

Vögel, Bernhild. "Wir waren fast noch Kinder": Die Ostarbeiter vom Rammelsberg. Goslar: Verlag Goslarsche Zeitung Karl Krause, 2003

von Looz-Corswarem, Clemens, ed. Zwangsarbeit in Düsseldorf: „Ausländereinsatz“ während des Zweiten Weltkrieges in einer rheinischen Grossstadt. Essen: Klartext Verlag, 2002.

von Trotha, Trutz. "Genozidaler Pazifizierungskrieg. Soziologische Anmerkungen zum Konzept des Genozids am Beispiel des Kolonialkrieges in Deutsch-Südwestafrika 1904-1907.“Zeitschrift für Genozidforschung 4.2 (2003):30-57.

Weiner, Amir. Making Sense of War: The Second World War and the Fate of the Russian Revolution. Princeton: Princeton University Press, 2001. 
Werbizky, G.G. Ostarbeiter Mail in World War Two: Documents and Correspondence. Tenafly: Hermitage Publishers, 1996.

Werner, Constanze. Kriegswirtschaft und Zwangsarbeit bei BMW. München: R. Oldenbourg Verlag, 2006.

Wilson, Andrew. The Ukrainians: Unexpected Nation. New Haven: Yale University Press, 2000.

Yones, Eliyahu. Die Strasse nach Lemberg: Zwangsarbeit und Widerstand in Ostgalizien 1941-1944. Frankfurt am Main: Fischer Taschenbuch Verlag GmbH, 1999.

Yurkevich, Miroslav. "Galician Ukrainians in German Military Formations and in the German Administration." In Ukraine during world war II. History and its aftermath. A Symposium, edited by Yury Boshyk and Roman Waschuk, 67-87. Edmonton: Canadian Institute of Ukrainian Studies, 1986.

Zeller, Joachim. "Symbolische Politik. Anmerkungen zur kolonialdeutschen Erinnerungskultur." In Völkermord in Deutsch-Südwestafrika. Der Kolonialkrieg (1904-1908) in Namibia und seine Folgen, edited by Jürgen Zimmerer und Joachim Zeller, 192-208. Berlin: Links, 2003.

Zimmerer, Jürgen. "Deutsche Kolonialgeschichte in neuerer Forschung." Archiv für Sozialgeschichte 43 (2003): 475-485.

---- "The birth of the Ostland out of the spirit of colonialism: a postcolonial perspective on the Nazi policy of conquest and extermination." In Colonialism and Genocide, edited by A. Dirk Moses and Dan Stone, 101-123. London: Routledge, 2007.

Zumbansen, Peer, ed. Zwangsarbeit im Dritten Reich: Erinnerung und Verantwortung: Juristische und zeithistorische Betrachtungen - NS-Forced Labor: Remembrance and Responsibility: Legal and Historical Observations. Baden-Baden: Nomos Verlagsgesellschaft, 2002. 